RICARDO MARCELO TICHAUER

\title{
MATRIZ DE PRIORIZAÇÃO APLICADA À \\ PESQUISA MINERAL NA PEQUENA MINERAÇÃO
}


RICARDO MARCELO TICHAUER

MATRIZ DE PRIORIZAÇÃO APLICADA À PESQUISA MINERAL NA PEQUENA MINERAÇÃO

Dissertação apresentada ao Departamento de Engenharia de Minas e de Petróleo da Escola Politécnica da Universidade de São Paulo para obtenção do título de Mestre em Ciências.

Área de concentração:

Engenharia Mineral

Orientador:

Prof. Dr. Giorgio de Tomi 
Este exemplar foi revisado e corrigido em relação à versão original, sob responsabilidade única do autor e com a anuência de seu orientador.

São Paulo, de de

Assinatura do autor:

Assinatura do orientador:

Catalogação-na-publicação

Tichauer, Ricardo Marcelo

Matriz de Priorização Aplicada à Pesquisa Mineral na Pequena Mineração /

R. M. Tichauer -- versão corr. -- São Paulo, 2016.

$71 \mathrm{p}$.

Dissertação (Mestrado) - Escola Politécnica da Universidade de São Paulo. Departamento de Engenharia de Minas e Petróleo.

1.Pesquisa Mineral (métodos de avaliação) 2.Ouro 3.Manganês I.Universidade de São Paulo. Escola Politécnica. Departamento de Engenharia de Minas e Petróleo II.t. 
Dedico essa dissertação à minha mãe, Elisabeth Jean Tichauer. 


\section{AGRADECIMENTOS}

Ao Departamento de Engenharia de Minas e de Petróleo da Escola Politécnica da Universidade de São Paulo, pela oportunidade de ter feito o curso de Mestrado em Engenharia Mineral.

Ao Prof. Dr. Giorgio de Tomi, pela orientação, apoio, e oportunidades de aprendizado e crescimento como profissional da mineração.

Ao Núcleo de Apoio à Pequena Mineração Responsável NAP.Mineração/USP, pelas oportunidades de pesquisa e troca de conhecimentos.

À CAPES, pelos recursos disponibilizados para a execução desta dissertação.

À minha família, pelo incentivo, confiança, e amor. 


\section{RESUMO}

Na mineração, grande parte das incertezas e riscos estão associados à caracterização geológica. A adoção das melhores práticas na pesquisa mineral resulta em menor risco e maiores eficácia e eficiência à operação, agregando valor ao empreendimento. No Brasil, em geral, a mineração em pequena escala emprega poucos recursos para a pesquisa mineral, e as melhores práticas são frequentemente ignoradas. Este trabalho aborda a incerteza geológica na mineração e como as melhores práticas de pesquisa mineral podem ser aplicadas na pequena mineração para diminuir riscos e incorporar valor ao projeto. A aplicação da Matriz de Priorização CEBIm em três projetos de pesquisa mineral em pequenos depósitos mostra como essa ferramenta pode ser utilizada de forma simples, prática, rápida e econômica para avaliação do nível de aderência do programa de pesquisa mineral às melhores práticas, que pode indicar a magnitude da incerteza geológica associada ao projeto.

Palavras-chave: Pequena Mineração. Pesquisa Mineral. Matriz de Priorização. 


\begin{abstract}
In mining, a large number of uncertainties and risks are associated with geological characterization. The adoption of best practices in mineral exploration results in lower risk and greater effectiveness and efficiency to the operation, adding value to the enterprise. In Brazil, in general, small-scale mining employs little resources for mineral exploration, and the best practices are often ignored. This work addresses the geological risks in mining and how best practices in mineral exploration can be applied in small mining to reduce risks and incorporate value to the project. The application of the CEBIm Priority Matrix in three projects of mineral exploration in small deposits shows how this tool can be utilized in a simple, practical, fast and economical way for assessment of the level of compliance of the mineral exploration program to the best practices, which can indicate the magnitude of geological uncertainty associated with the project.
\end{abstract}

Keywords: Small-scale Mining. Mineral Exploration. Priority Matrix. 


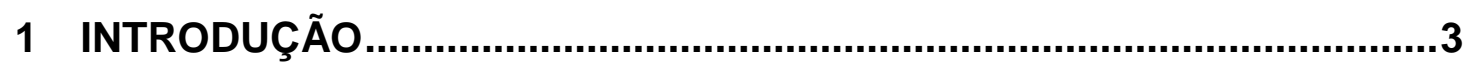

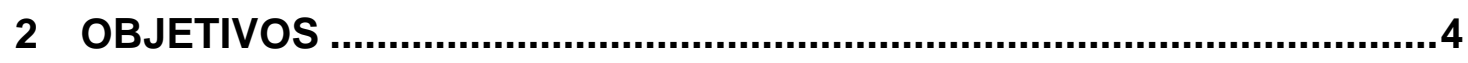

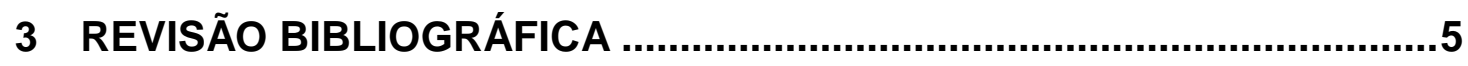

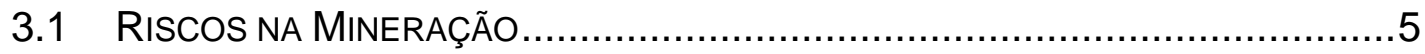

3.1.1 Risco ..................................................................................... 5

3.1.2 Riscos Associados às Condições do Mercado...........................8

3.1.3 Riscos Associados às Ineficiências Operacionais .....................7

3.1.4 Riscos Associados às Incertezas Geológicas .......................... 7

3.2 Riscos E VALOR NA PESQUISA MinERAL ..................................... 13

3.2.1 Riscos e Retorno na Pesquisa Mineral ......................................13

3.2.2 Avaliação e Valor de Projetos de Mineração...............................14

3.3 Melhores Práticas de Pesquisa Mineral .................................... 18

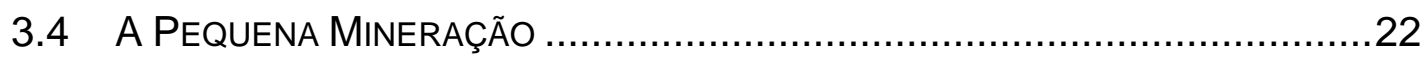

3.5 Melhores Práticas de Pesquisa na Pequena Mineração................233

3.6 PESQUISA EM DEPÓSITOS DE MANGANÊS .......................................24

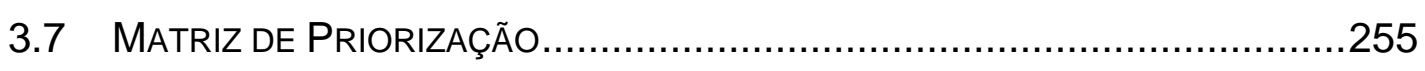

3.7.1 Definição de Matriz de Priorizaçâo........................................255

3.7.2 A Matriz de Priorização CEB ...................................................25

4 MATERIAIS E MÉTODOS ............................................................277

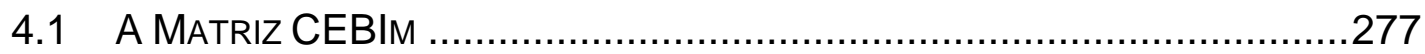

4.2 AplicaÇÃo I: Garimpo de OURO EM ItAituBA, PA ............................322

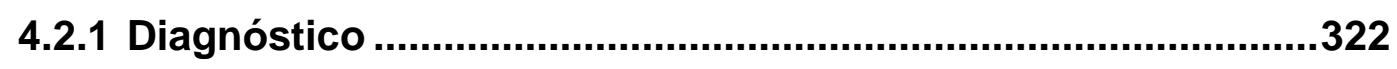

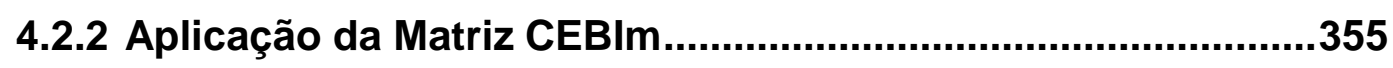

4.3 Aplicação II: Pesquisa de Jazida de Manganês em Caetité, BA ......366

4.3.1 Levantamento Topográfico......................................................388

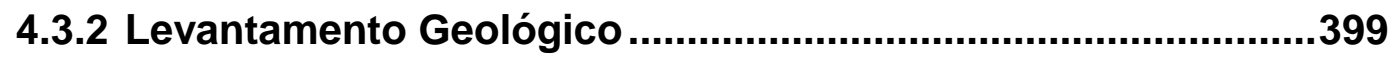

4.3.3 Abertura de Poços e Trincheiras...........................................411

4.3.4 Amostragem e Análise ......................................................433

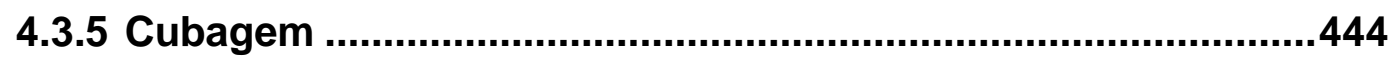

4.3.6 Aplicação da Matriz CEBIm..................................................455 
4.4 APlicaÇÃo III: PESQUiSA de JaZIDA dE MANGANÊS EM ITAPIRA, SP ......466

4.4.1 Levantamento Topográfico....................................................477

4.4.2 Mapeamento Geoestrutural ................................................499

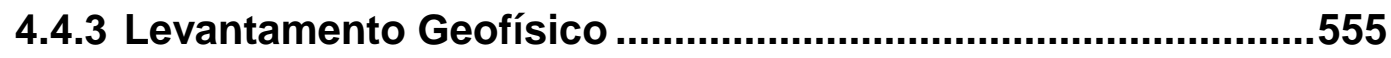

4.4.4 Modelo Geológico Preliminar ................................................588

4.4.5 Plano de Sondagem .................................................................61

4.4.6 Aplicação da Matriz CEBIm.......................................................655

5 RESULTADOS E DISCUSSÕES ....................................................666

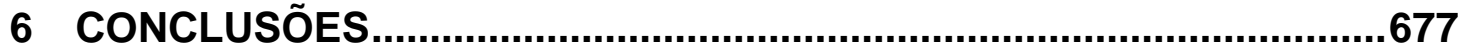

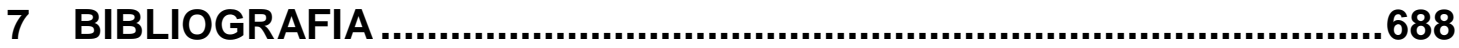




\section{INTRODUÇÃO}

Segundo Connolly e Orsmond (2011), a alta nos preços dos metais entre 2003 a 2008 representou o mais forte e sustentado crescimento do setor mineral desde a Segunda Guerra Mundial. Connolly e Orsmond explicam que esse fenômeno foi impulsionado pelo crescimento da demanda nas economias emergentes e, em particular, da China. Raggi (2010) mostra que, durante esse período, um grande número de indivíduos e pequenas empresas começou a investir em mineração. Raggi demonstra como as "junior exploration companies", empresas que surgiram ao redor do mundo para investir em exploração mineral e desenvolvimento de projetos de mineração, acabaram sendo responsáveis por boa parte da alavancagem dos empreendimentos minerais na primeira década do século XXI. Da mesma forma, pequenos mineradores, mesmo aqueles com pouca ou nenhuma experiência no setor, podem contribuir com o desenvolvimento da mineração no Brasil e no mundo.

De acordo com Gamarra Chilmaza (2005), a mineração em pequena escala é, em sua maior parte, informal, e não atende às exigências legais. Destaca, no entanto, que parte desses operações são formais, com títulos de terra e licenças do governo, pagando impostos e atendendo às responsabilidades sociais e ambientais. Buxton (2013) estimou que a mineração artesanal e de pequena escala contribui de 15 a 20\% da produção global de minerais e metais.

Em geral, a pequena mineração não disponibiliza de recursos suficientes para investir em um programa de pesquisa mineral responsável, que possa reduzir significativamente os riscos associados às incertezas geológicas do projeto, limitando o aproveitamento do potencial do empreendimento. A pesquisa é frequentemente realizada da forma mais econômica possível, sem que as melhores práticas de pesquisa mineral sejam observadas e incorporadas.

A adoção das melhores práticas no gerenciamento empresarial resulta em menor risco e maiores eficácia e eficiência à operação, agregando, portanto, valor ao empreendimento. Na mineração, grande parte dos riscos estão associados à caracterização do ambiente geológico. Portanto, a adoção das melhores práticas na pesquisa mineral agrega valor ao projeto. Na mineração em pequena escala, boa parte desse valor se encontra represado. Este estudo avalia como as melhores 
práticas de pesquisa mineral podem ser aplicadas na pequena mineração para diminuir riscos e incorporar valor ao projeto.

Nesse estudo, são abordados inicialmente os riscos considerados mais relevantes na mineração, em especial aqueles associados à caracterização geológica. São verificadas, também, as diretrizes de melhores práticas mais utilizadas no Brasil. A seguir, é proposta a Matriz de Priorização CEBIm, uma ferramenta prática e econômica para avaliação do nível de aderência entre a pesquisa mineral realizada em um projeto de produção mineral e as melhores práticas de pesquisa mineral. Finalmente, é demonstrado, através da aplicação da Matriz CEBIm em três pequenos depósitos minerais no Brasil, como essa ferramenta pode ser útil para avaliação do nível de incerteza geológica e para a priorização de ações para redução das incertezas geológicas associadas ao projeto.

\section{OBJETIVOS}

O principal objetivo neste trabalho é a compreensão do potencial de valor que um projeto de mineração deixa de contabilizar, ou seja, o valor represado, em consequência de uma pesquisa mineral que não adota os critérios de melhores práticas.

As questões de pesquisa são:

- Quais os riscos associados aos projetos de pequena mineração?

- Qual é o impacto da pesquisa mineral nos riscos da pequena mineração?

- $\quad$ As melhores práticas em pesquisa mineral podem ser aplicadas na pequena mineração?

Para atender a esse objetivo, é proposta uma Matriz de Priorização para avaliação da aderência da pesquisa mineral de um projeto de mineração em pequena escala às melhores práticas de pesquisa mineral, e consequente indicação da magnitude das incertezas geológicas existentes no projeto. 


\section{REVISÃO BIBLIOGRÁFICA}

\subsection{RISCOS NA MINERAÇÃO}

Riscos são inerentes a todos empreendimentos comerciais. Empresas de sucesso gerenciam adequadamente seus riscos. Em grande parte do setor produtivo, os maiores riscos são aqueles associados às alterações das condições mercadológicas e às ineficiências operacionais. No entanto, na mineração a incerteza geológica pode representar riscos tão ou mais importantes do que aqueles ligados às condições do mercado e do sistema produtivo.

\subsubsection{Risco}

Singer e Kouda (1999) definem risco como a possibilidade de uma ação ou de um processo gerar uma falha ou uma perda. Para Kreuzer e Etheridge (2010), risco na mineração se refere à probabilidade de um projeto produzir um resultado econômico não desejado. Estimam ser necessário pesquisar pelo menos 200 áreas nunca exploradas para que seja identificado um projeto de mineração viável. Raggi (2010) verificou que, no Brasil, dos 430.339 requerimentos de pesquisa protocolados no DNPM entre 1988-2009, apenas 4.739, ou pouco mais de 1\%, receberam outorga de concessão de lavra. Mesmo considerando-se que parte desses requerimentos tenham sido protocolados por fazendeiros interessados em proteger suas áreas de empreendedores de mineração, o número de concessões de lavra concedidos é pequeno em um período de 21 anos, com média de 225 concessões por ano.

Kreuzer e Etheridge afirmam ainda que uma avaliação de direitos minerários deve embutir todas as variáveis relevantes para a determinação do valor do ativo, como ambiente geológico, tipo de mineralização, teor, tonelagem, incentivos governamentais, preço dos produtos, condições de lavra e beneficiamento, infraestrutura e acesso, segurança jurídica e risco soberano. No entanto, a maior parte dos métodos aplicados na avaliação de direitos minerários é determinístico e tende a ignorar os riscos inerentes ao setor.

Partington (2010) menciona que empresas de mineração são confrontadas com o problema de como avaliar e planejar adequadamente seus projetos em função das incertezas de preço e teor de minério. Singer e Kouda afirmam que a maior parte dos 
fracassos por razões econômicas ou técnicas na mineração derivam de preços dos produtos abaixo do esperado, reservas de minério menores do que estimado, custo superior ao previsto, dificuldades de beneficiamento maiores do que planejado, variações nas taxas de câmbio, ou atraso do desenvolvimento do projeto.

Segundo Singer e Kouda, o risco pode ser gerenciado para aumentar o retorno econômico requerido para um investimento, e sugerem o uso adequado de filtros econômicos e da teoria geológica para a redução da probabilidade de fracasso.

\subsubsection{Riscos Associados às Condições do Mercado}

Szamałek (2011) acredita uma crise global de recursos minerais é improvável de ocorrer nas próximas várias centenas de anos, uma vez que progresso técnico e pesquisa possibilitam a descoberta e a viabilidade de novos depósitos minerais. Destaca que grandes quantidades de minerais podem ser encontradas e extraídas do fundo do mar, das partes mais profundas da crosta de terra, de resíduos industriais e através da reciclagem. Já para Tilton (2010), são grandes as incertezas sobre a oferta e a demanda de bens minerais no futuro, e consequentemente sobre os preços reais dos bens minerais. Apesar de destacar as incógnitas geológicas, Tilton sustenta que, para os próximos 50 a 100 anos, o risco de escassez de minerais não parece estar entre os problemas mais importantes a serem enfrentados pela sociedade.

Raggi explica que, independentemente dos riscos do mercado no longo prazo, os riscos de curto prazo são significativos e podem causar grande impacto nos projetos de mineração. O ciclo de alta nos preços dos metais entre 2003 a 2008, por exemplo, foi interrompido abruptamente com o colapso dos preços das commodities no segundo semestre de 2008. É mais difícil avaliar um direito/concessão minerária durante ou após um impacto, porque as emoções, percepções e perspectivas são alteradas. É o que se denomina "volatilidade" no mercado financeiro.

Ainda segundo Raggi, uma análise histórica do preço do ouro pode ilustrar os riscos da volatilidade possível de ser provocada com a conflagração de eventos mundiais de grande impacto. O ouro é cotado pelo mercado londrino desde o ano de 1344. No período entre 1662 e 1939 seu valor era £3.894 por onça troy. O início da II Grande Guerra causou um impacto de tal magnitude que resultou no abandono da 
cotação do ouro em libra esterlina. Nessa época, enquanto o Tesouro inglês cotava o ouro £3.894, o preço chegava a £7.717 no mercado livre.

Evatt et al. (2012) afirmam que os riscos associados às incertezas econômicas e mercadológicas são significativos na mineração, mas verificaram que, enquanto metodologias que representam incerteza física estão relativamente bem desenvolvidas, metodologias que podem levar em conta incerteza econômica parecem estar menos desenvolvidas. Para Singer e Kouda (1999), uma forma de se reduzir o risco associado à variabilidade de preços é a busca de depósitos minerais que contêm vários metais, na expectativa de que quando o preço de alguns metais declina o de outros pode subir. Destacam também que a variação dos preços durante a vida da mina pode ser controlada eficazmente por "hedging", ou seja, o uso de instrumentos financeiros para limitar as perdas associadas à queda de preço do produto.

\subsubsection{Riscos Associados às Ineficiências Operacionais}

Steinberg e De Tomi (2010) abordam a importância da modernização e da otimização para que a diminuição de riscos e aumento da eficiência da cadeia de produção mineral, garantindo assim produção na quantidade e na qualidade de produto desejadas. Tal garantia, que é difícil de manter devido à natureza intrínseca da incerteza geológica, só pode ser alcançada através de um aumento da eficiência das cadeias de produção mineral. O conceito de "lean-mining" proposto pelos autores implica na identificação e compreensão das etapas do processo em que há criação de valor e onde intervenções para melhoria devem ser implementadas.

Botín et al. (2011) mencionam que análises de risco em estudos de viabilidade de mina para obtenção de financiamento bancário baseiam-se na modelagem estocástica do projeto e do "Valor Presente Líquido" (VPL), mas que, na maioria dos casos, não constitui uma análise verdadeiramente abrangente dos riscos associados com incertezas técnicas e de gestão. Em consequência, são de pouca utilidade para a gestão de riscos e otimização do projeto.

Como incerteza e riscos técnicos podem ser avaliados para cada etapa do ciclo de vida do projeto, Botín et al. propuseram uma abordagem de gestão de riscos e um processo de otimização de valor agregado em etapas, e introduziram o conceito de 
"Mining Project Risk Management" (MPRM). O MPRM foi desenvolvido para identificar e gerenciar o risco das decisões ao longo da cadeia de valor do projeto, desde a exploração até o fechamento da mina. Trata-se de uma metodologia de gestão de iscos e otimização do projeto nas fases de exploração, de análise de viabilidade, de orçamento e de auditoria, ou para gestão de riscos em minas operacionais.

Para Botín et al., identificar, quantificar, e minimizar riscos técnicos associados com as decisões de investimento é um desafio fundamental para os tomadores de decisão da indústria mineral e investidores. No conceito de MPRM, a gestão de um projeto de mineração é vista como um processo de redução gradual do risco, em que quantidades cada vez maiores de capital são investidas através do tempo para reduzir a incerteza e risco financeiro. No final de cada etapa, há uma decisão de abortar ou continuar com base nas informações existentes e, se a decisão for de continuar, o projeto entra na fase seguinte de avaliação em uma maior intensidade de capital. $\mathrm{Na}$ última fase, o projeto pode alcançar um nível de risco financeiro que é aceitável para os investidores e continuar a ser implementado. Uma característica fundamental do MPRM é que o risco do projeto é modelado por uma matriz, que apresenta os riscos associados a cada processo e a origem dos riscos. No MPRM, em resumo, o gerenciamento de riscos e o processo de otimização é realizado através da alocação eficiente dos recursos financeiros à cada etapa do processo de produção mineral.

\subsubsection{Riscos Associados às Incertezas Geológicas}

Abdel Sabour e Poulin (2010) explicam que a maioria dos projetos de mineração implica em múltiplos investimentos em diferentes fases, e inclui possibilidades de expansão da mina da vida além do inicialmente estimado. Tais opções estratégicas de expansão podem ter uma influência significativa sobre a viabilidade econômica do projeto de mineração. Abdel Sabour e Poulin estudaram um caso de um hipotético projeto de cobre para e sugeriram procedimentos para análise de opções de expansão de mina sob incerteza. Os resultados indicam que as regras de decisão para o exercício da opção de expansão de mina são altamente dependentes do nível de incerteza associada.

Para Singer e Kouda, uma forma de reduzir o risco na exploração mineral é aumentar o número de áreas examinadas, e outra forma é diminuir a probabilidade de 
fracasso. Os riscos geológicos mais significativos estão associados ao volume do depósito, seguidos pelos riscos associados às estimativas de teor. Portanto, o maior potencial para redução do risco na pesquisa mineral está na redução das incertezas associadas com estimativas de volume. Por isso, empresas de exploração geralmente buscam um tamanho mínimo de depósito, e depósitos minerais de classe mundial são alvos primários da exploração de muitas empresas de mineração.

Singer e Kouda mostram também que é possível reduzir o risco financeiro na mineração com a expansão sequencial de uma mina. Esta estratégia resulta na redução do risco associado à exploração mineral, do capital exposto em estágios iniciais e do valor presente do capital investido.

Segundo Bárdossy e Fodor (2001), as principais incertezas associadas a projetos de exploração mineral são as ligadas à variabilidade natural da geologia, as derivadas da determinação conceitual da modelagem geológica, e as resultantes de erros de amostragem e de medição dos dados geológicos. Para Capponi (2012), a incerteza geológica é um dos principais fatores que contribuem para o insucesso de um projeto de mineração.

Kreuzer et al. (2007) analisou o sucesso das 179 "junior exploration companies" australianas de capital aberto entre julho de 2001 e junho de 2006, e verificaram que, dentre os 970 projetos controlados por essas empresas, apenas 10 se tornaram minas. Portanto, nesse período de seis anos, apenas 1 em cada 97 (cerca de 1\%) projetos obteve sucesso.

Capponi (2012) destaca o papel crescente da simulação estocástica na construção de modelos para analisar o risco associado de incerteza de teores em depósitos minerais. Capponi aborda o controle e planejamento de lavra incorporando a incerteza associada ao teor do minério, e a sensibilidade do retorno financeiro em função das variações e incertezas relacionadas ao modelo geológico e estimativa de teores. Adiciona que a medição e gerenciamento do risco geológico na tomada de decisões podem ser realizados em várias etapas do empreendimento, desde a pesquisa mineral até o sequenciamento de lavra e a exaustão das reservas.

Annels (1992) menciona que o uso de métodos de cálculo de reservas não pode ser apenas um simples exercício de matemática e geometria e deve ser associado à geologia. Sugere o acompanhamento de geólogos experientes na exploração de depósitos minerais, e ressalta que o bom entendimento da geologia local é importante para influenciar ou restringir o cálculo de reservas minerais. 
Para Palmieri (2013), a diminuição dos riscos associados a erros na interpretação geológica é fator fundamental para a otimização da operação em toda a cadeia de produção mineral. Sua tese de mestrado pode ilustrar a importância da ampla compreensão da geologia local. Palmieri teve como objetivo a caracterização geológica e avaliação estatística do minério de nióbio do Depósito Morro do Padre, em Catalão II, Goiás, e a "elaboração de um modelo geológico que permitisse compreender a estrutura e a evolução da mineralização primária em rocha fresca e suas relações com a mineralização supergênica".

O depósito de nióbio do Morro do Padre foi descoberto na década de 1980, porém, até 2005, pouco trabalho de exploração e caracterização havia sido realizado. De 2005 a 2010 foram realizadas campanhas de sondagem para a modelagem geológica e econômica tanto da porção alterada quanto da primária do depósito. Os dados de geoquímica exploratória foram interpolados por krigagem ordinária para obter teores estimados ao longo de todo o corpo mineralizado. Através de análises químicas da rocha e do pirocloro, assim como estudos mineralógicos e texturais, foram definidos os tipos litológicos e a evolução magmática do minério primário. Dados mineralógicos e texturais do solo sobre o minério primário permitiram compreender a distribuição, a estrutura e as variações do minério supergênico. Ao final, foi possível estabelecer a geometria, as relações de contato e a evolução das rochas e dos minérios primário e supergênico do depósito.

A importância da participação do geólogo na compreensão da gênese do depósito pode reduzir consideravelmente o risco associado à interpretação equivocada da geologia. No trabalho de Palmieri, foi observado que "a modelagem de teores de nióbio mostrou que os diques de nelsonito e, subordinadamente, carbonatito controlam a distribuição do minério, tanto em rocha fresca quanto, parcialmente, no solo".

Abedi e Norouzi (2012) revelaram como informações geológicas, geofísicas e geoquímicas foram coletadas, analisadas e integradas para a geração de um mapa de exploração mineral do depósito de cobre em Now Chun, Irã. Uma classificação binária desses aspectos apenas indica as áreas que devem ser sondadas e as áreas a serem descartadas. O caso mencionado ilustra o conceito de classificar as áreas em diferentes classes de probabilidade de sucesso e priorizar as áreas, resultando em maior precisão do mapa e menor risco para a sondagem. 
Freitas et al. (2015) demostram como o planejamento de lavra lida com a busca pela sequência mais rentável ao longo da vida de uma mina. A dinâmica da extração de minério e estéril e a incerteza da distribuição espacial dos teores tornam complexa a busca pela otimização dos processos na produção mineral. Ignorar o risco associado à incerteza geológica pode levar a planos de produção irrealistas. Freitas et al. mostram como um conjunto de procedimentos foi aplicado na mina de cobre de Sossego, Pará, que permitem avaliar a sensibilidade do projeto de lavra à incerteza do teor. A aplicação dessa metodologia contribuiu com a tomada de decisões em relação às campanhas de sondagem, à revisão do sequenciamento de lavra, à identificação de área de alto potencial com baixo risco, e à combinação de frentes de lavra a fim de minimizar o impacto de áreas de alto risco. A análise e gerenciamento de risco geológico no planejamento do ciclo de vida da mina resulta em melhor resultado técnico e econômico.

Partington (2010) propõe um método estocástico que incorpora a incerteza do teor do minério na avaliação de projetos de mineração. Abordar o teor do minério através de um processo estocástico possibilita a produção infinita de simulações do teor do minério a ser lavrado e do valor do projeto. O estudo apresenta um exemplo em que a inclusão da incerteza de preço e teor de minério adiciona até cinco milhões de dólares no valor do projeto. Quando o preço do minério está alto, a opção de não processar minério de teor baixo raramente é usada e adiciona relativamente pouco valor. No entanto, em um cenário de baixos preços de minério e grande volatilidade no teor de minério, a opção de não processar minério de teor baixo aumenta sensivelmente o valor da mina.

Segundo Faria Junior et al. (2010), o conhecimento geológico das diferentes litologias que formam uma jazida é fundamental para a garantia da qualidade esperada do minério, mas não é suficiente. Além do conhecimento dos diferentes domínios geológicos, que abrange uma série de atividades exploratórias e tem como produto final um modelo tridimensional de blocos, obtido com a utilização de técnicas geoestatísticas, é igualmente importante a estimativa de teores, através de técnicas de interpolação como a krigagem.

David (1982) indica as etapas para a estimação geoestática da distribuição dos teores na modelagem de um corpo mineralizado: (i) calcular os variogramas do depósito, (ii) usar modelo um matemático adequado, (iii) calcular todas as variações relevantes e (iv) fazer os cálculos de krigagem. 
Ribeiro et al. (2012) afirmam que, durante os estágios iniciais de desenvolvimento de uma nova mina, um depósito pode ser considerado geologicamente conhecido se a informação disponível for suficiente para dar suporte ao planejamento de longo prazo, sem desvios significativos em relação ao depósito real. Explicam que dois problemas podem ocorrer: a qualidade do minério pode ser superestimada ou subestimada e a interpretação do volume pode ser equivocado. Enquanto o primeiro problema depende, basicamente, do espaçamento utilizado na amostragem e da garantia de qualidade das amostras, podendo ser adequadamente tratado com a utilização de técnicas geoestatísticas tradicionais, o segundo problema depende não apenas do espaçamento das amostras como também da complexidade geológica do corpo mineralizado.

Ribeiro et al. propõem uma metodologia para definir malhas ótimas de sondagem para aplicação em jazidas de minério de ferro no Quadrilátero Ferrífero e em Carajás. Estudos comparativos foram realizados em minas existentes e em projetos, obtendo-se malhas de sondagem indicativas por província. Para novas áreas, criou-se uma metodologia de pesquisa sequencial, com adensamento gradativo da malha de sondagem e avaliação dos riscos em cada etapa. Ribeiro et al. destacam que esta metodologia é válida se o modelo geológico for correto, ou seja, se o espaçamento da amostragem disponível durante a construção do modelo for suficiente. Observam, no entanto, que essa condição ideal não existe, principalmente nas fases iniciais da exploração mineral, quando há escassez de sondagem. Nesse caso, os modelos conceituais baseados em informações indiretas, como dados obtidos através de métodos geofísicos, ou diretas, como mapeamento geológico e abertura de trincheiras, podem ser utilizados para a construção de variogramas preliminares, que devem ser detalhados e aperfeiçoados com a intensificação da campanha de sondagem.

Enfim, o risco geológico está associado a principalmente três fatores, isolados ou combinados:

- Informação insuficiente;

- Informação incorreta;

- Interpretação geológica errônea. 


\subsection{Riscos e Valor na Pesquisa Mineral}

\subsubsection{Riscos e Retorno na Pesquisa Mineral}

Para Baurens (2010), investimentos em "commodities" têm sido atraentes como investimento a longo prazo, pois o valor do investimento é resguardado em tempos de crise econômica e fornecem uma proteção contra a desvalorização da moeda. Por outro lado, Singer and Kouda destacam que a exploração mineral é uma atividade econômica que envolve riscos e incertezas. Portanto, devem ser consideradas nos processos de tomada de decisão não apenas uma expectativa de valor do projeto, mas também as probabilidades dos diversos resultados possíveis, inclusive retorno econômico negativo.

Ball e Brown (1980) estudaram as taxas de retorno de 1.029 empresas de mineração de capital aberto negociadas na bolsa de valores de Sydney, Austrália, entre janeiro de 1958 e fevereiro de 1979, e concluíram que o retorno médio de $11.9 \%$ por ano no período foi baixo em função do alto risco associado à atividade.

Raggi ilustra com o caso Bre-X como riscos associados a erros de caracterização geológica, intencionais ou não, podem implicar em resultados econômicos desastrosos. Em 1993, a Bre-X adquiriu uma propriedade em área de floresta junto ao rio Busang, em Borneo, na Indonésia. Em 1997, relatórios estimavam as reservas em 200 milhões de onças troy, ou mais de 6.000 toneladas de ouro. 0 valor da Bre-X chegou a US\$ 4.4 bilhões em 1997, quando a empresa vendeu seus direitos (45\% das ações) à empresa americana Freeport-McMoRan. Um mês após ser concluída a transação, a fraude foi descoberta. Análises em amostras-chave revelaram que havia quantidades insignificantes de ouro na área. O escândalo provocou uma reação das bolsas de valores internacionais, que editaram normas e auditorias para creditar conteúdos minerais e diferenciar recursos de reservas. Segundo Raggi, ocorreram 30.386 cessões de direitos minerários no Brasil entre 1999-2009. Considerando-se o crescente número empreendedores iniciantes no setor, é fundamental que os riscos geológicos sejam minimizados a fim de que situações como a da Bre-X sejam evitadas. 
Para Partington (2010), o valor do risco da exploração é determinado combinando-se os valores de probabilidade geológicas com os parâmetros econômicos. Partington afirma que há uma variedade de ferramentas e técnicas que, usadas em conjunto com modernos sistemas de informação geográfica e com o conceito de sistema mineral, permitem análise sofisticada de risco econômico de projetos de mineração. Partington demonstra, através do estudo de um caso de exploração mineral de cobre e ouro em Oman, que a combinação de dados de geologia, geoquímica e geofísica em um único mapa resulta em compilação de dados eficaz, em controle digital dos dados de boa qualidade, e em bom nível de compreensão da geologia. A compreensão adequada dos fatores geológicos é fundamental para o controle dos riscos e a otimização do retorno na pesquisa mineral.

\subsubsection{Avaliação e Valor de Projetos de Mineração}

Lilford (2011) destaca que quanto menor a incerteza em relação às características geológicas de um projeto mineral e maior a variedade de métodos utilizados, mais precisos são os resultados, e mais exata é a avaliação do projeto mineral. O autor apresenta as definições de reserva provada, reserva provável, recurso medido, recurso indicado e recurso inferido, normalmente utilizadas na avaliação de projetos de mineração.

Reserva Provada: A parte economicamente recuperável de um recurso mineral medido. Inclui materiais e estimativa de perdas que possam ocorrer durante a lavra. Avaliações adequadas foram realizadas, e incluem a consideração de diversos fatores, como de lavra, processamento mineral, de economia e mercado, jurídicas, ambientais, sociais e governamentais. A avaliação é baseada em amostragem e indica a possível lucratividade da produção mineral.

Reserva Provável: A parte economicamente recuperável de uma parte do recurso mineral indicado e talvez medido. Há menos informação técnica sobre a ocorrência do que a Reserva Provada.

Recurso Medido: Parte de um recurso mineral para a qual tonelagem, densidade, forma, características físicas, conteúdo mineral e teor podem ser estimados com um elevado nível de confiança. É baseado na exploração detalhada, amostragem e testes de informações obtidas através de técnicas adequadas em 
afloramentos, trincheiras, poços, e furos de sonda. O espaçamento entre os pontos de coleta de amostras é próximo o suficiente para confirmar a ocorrência geológica e a continuidade do teor.

Recurso Indicado: Parte de um recurso mineral para a qual tonelagem, densidade, forma, características físicas, conteúdo mineral e grau podem ser estimados com razoável nível de confiança. É baseado na exploração, amostragem e testes de informações obtidas através de técnicas adequadas de locais como afloramentos, trincheiras, poços, e furos de sonda. O espaçamento entre os pontos de coleta de amostras não é próximo ou adequado o suficiente para confirmar a ocorrência geológica e a continuidade do teor, mas as informações são suficientes para se presumir a continuidade de teor da ocorrência geológica.

Recurso Inferido: Parte de um recurso mineral para o qual tonelagem, o teor e o conteúdo mineral pode ser estimado com um baixo nível de confiança. É inferido através de evidências geológicas a ocorrência geológica e a continuidade do teor. É baseado em informações limitadas, de qualidade incerta, e de pouca confiabilidade obtidas em afloramentos, trincheiras, poços, e furos de sonda.

Dimitrakopoulos (2011) mostra como as abordagens convencionais para estimar reservas, otimizar planejamento de lavra, e prever resultados, resultam muitas vezes em previsões enviesadas. Para o autor, isso se deve principalmente à propagação não-linear de erros na compreensão das jazidas ao longo da cadeia de produção mineral. Propõe como novo paradigma de planejamento a integração de dois elementos, a simulação estocástica e otimização estocástica. Esta abordagem resulta em um quadro matemático que integra incerteza geológica, projeto da mina, planejamento de produção mineral, e avaliação de projetos e operações de mineração.

Um ponto de partida para otimização é a representação de um depósito mineral no espaço tridimensional através de um modelo de jazida e dos blocos de mineração. Esse modelo de blocos é utilizado para otimizar planejamento e sequenciamento de lavra. No entanto, ao invés de um único modelo geológico como instrumento para otimização da mina, pode ser usado um conjunto de modelos, resultantes dos mesmos dados disponíveis. Diferentes interpretações dos dados disponíveis podem resultar em vários modelos de distribuição de teores igualmente prováveis. A disponibilidade de múltiplos modelos igualmente prováveis de um depósito permite a análise de sensibilidade do desenho da cava e do planejamento de lavra a longo prazo à 
incerteza geológica. A abordagem estocástica de otimização da lavra resulta, portanto, em maior valor presente líquido do projeto de mineração. Otimizadores convencionais de sequência de lavra são determinísticos e presumem conhecimento perfeito do corpo mineralizado a ser considerado. A principal desvantagem de técnicas de estimativa e as abordagens tradicionais de planejamento é que eles são incapazes dar conta da variabilidade espacial dos teores do depósito. Ignorar esta importante fonte de risco e incerteza pode levar a expectativas irreais de produção. A abordagem apresentada integra modelagem estocástica de jazidas e otimização estocástica de modo complementar.

Um otimizador estocástico avalia um conjunto de blocos, mas usa simultaneamente todas as combinações possíveis de valores econômicos dos blocos de mineração do corpo que está sendo considerado. Como resultado, obtém-se um planejamento mais robusto, que pode maximizar o potencial do depósito (por exemplo, maior VPL e produção de metal) e, ao mesmo tempo, minimizar desvantagens (por exemplo, não atingir metas de produção e perdas associadas).

Dimitrakopoulos mostra como a abordagem estocástica de uma grande mina de ouro levou a um aumento de $28 \%$ do VPL ao longo da vida da mina, em comparação com as práticas tradicionais empregadas. O mesmo estudo indica que, além disso, a abordagem estocástica leva ao desvio potencial substancialmente menor de metas de produção, ou seja, contribui com a redução do risco operacional. Dimitrakopoulos menciona também estudos em que os limites da cava e a tonelagem total a ser lavrada podem ser cerca de 15\% maiores com abordagem estocática do que com análise convencional, acrescentando cerca de $10 \%$ de valor presente líquido ao projeto.

Conforme exposto por Lilford, as avaliações de projetos minerais são feitas através de três metodologias básicas, a de custo, a de receita, e a de mercado. A metodologia de custo envolve a avaliação dos custos da exploração mineral e a utilização de um múltiplo para a determinação do valor do projeto. A metodologia de receita emprega o fluxo de caixa descontado esperado, o valor presente líquido, incluindo análise de sensitividade e cenários, opões reais e simulação Monte Carlo. A metodologia de mercado se utiliza de valores atribuídos à área a ser explorada e/ou à quantidade de metal a ser calculado ou produzido. Geralmente mais de um método pode ser aplicado para a avaliação de um projeto mineral. A utilização desses métodos depende da existência dos dados necessários para condução da avaliação. 
Segundo Uberman (2014), está claro que a maioria das avaliações de ativos minerais deverá estar baseado na abordagem de receita, exigindo assim a construção de modelos financeiros abrangentes, refletindo uma grande variedade de parâmetros das áreas de geologia, mineração, meio-ambiente, finanças, mercadologia e política, para citar os mais importantes. Tais modelos devem cobrir o longo-prazo intrínseco a projetos de mineração, tornando-se praticamente impossível o estabelecimento de regras metodológicas rígidas.

Baurens indica que vários métodos estão disponíveis para estimar o valor de uma empresa de mineração, mas muitos não são aplicáveis ou úteis. A razão é a natureza específica da indústria de mineração. Além do risco de financiamento à exploração e à produção mineral, existem a variabilidade do preço, mudanças operacionais, alterações na composição do capital, e volatilidade no mercado. Consequentemente, mesmo tradicionais métodos como fluxo de caixa descontado, múltiplos relativos, ou opções reais não podem ser aplicados sem ajustes e adaptações. Por exemplo, metodologias de avaliação com base no fluxo de caixa ou lucros podem não ser relevantes para a avaliação de uma empresa de exploração mineral que não tenha bens de produção ou geração de receitas. Estudo de viabilidade é um estudo abrangente de um depósito mineral em que os fatores geológicos, de engenharia, jurídicos, operacionais, econômicos, sociais, ambientais e outros são considerados em detalhes suficientes para que uma instituição financeira possa financiar o desenvolvimento do depósito para a produção mineral.

Baurens destaca que, na avaliação de empresas de mineração, dado o alto nível de incerteza geológica, é especialmente difícil se estimar valores de produção dos próximos anos. Os preços dos produtos minerais também são muito difíceis de se prever e serão diferentes mesmo entre analistas profissionais. Outras variáveis, como fator de desconto, custos e metodologia utilizada, também variam de analista para analista. Para Baurens, nenhum método de avaliação pode ser considerado certo ou errado. Os três métodos tradicionais - múltiplos, fluxo de desconto de caixa e opções reais não devem ser vistos como independentes, mas complementares.

Raggi prevê que a análise de opções reais será adotada de forma crescente para projetos complexos, como um complemento importante ao método do fluxo de caixa descontado. Turek e Sojda (2014) também defendem o uso de opções reais na determinação do valor da empresa de mineração. Apresentam um método fundamentado em três cenários: otimista, mais provável, pessimista. Nesta base, são 
indicados os valores que, baseado na ideia de opções reais, permite indicar um valor concreto. Um método clássico de fluxo de caixa descontado utiliza um cenário com base nos quais é determinado um valor. Na avaliação de opções reais, a estimativa do valor também é baseada no método de fluxo de caixa descontado, mas o valor do projeto é função das probabilidades adotadas para os cenários.

Dimitrakopoulos e Sabour (2007) apresentam a utilidade e as vantagens da AOR (Avaliação de Opções Reais) sobre o método estático do VPL, e demonstram que a AOR pode lidar com a complexidade dos projetos de mineração e contribuir para a tomada de decisões que melhorem o valor do projeto. Dimitrakopoulos e Sabour propõem um método de AOR baseada em simulações que pode lidar com várias incertezas, e verificam o impacto que a AOR pode ter sobre a rentabilidade do projeto. Em um estudo de caso de sequenciamento de produção em uma mina de ouro australiana, suscetível a múltiplas fontes de incerteza, foi demonstrado que o valor maximizado da mina com AOR é de 11\% a 18\% mais alto do que com o método do VPL.

Botin Gonzalez et al. (2011) elaboraram uma análise de opções reais que foi executada com sucesso para medir o impacto e gerir o risco associado à incerteza de diluição em um projeto de mineração. Os resultados mostram que as opções avaliadas apresentaram uma melhoria no VPL de 18\% sobre o cenário-base, com $96 \%$ de confiança de que alimentação de minério na planta será realizado conforme planejado. A crescente complexidade dos projetos de mineração deve levar a um aumento da percepção dos benefícios da aplicação da AOR para gerenciar riscos e aproveitar a vantagem potencial dos sistemas de produção mineral.

\subsection{Melhores Práticas de Pesquisa Mineral}

Para Uberman, tendo-se em consideração as associações profissionais e os órgãos reguladores, deve-se visar a harmonização dos métodos de avaliação de projetos de mineração, limitando redundâncias desnecessárias e eliminando o uso diferente das mesmas noções e métodos de avaliação. É fundamental, também, a existência de profissionais qualificados capazes de entender qualquer questão de avaliação e corretamente aplicar métodos apropriados. 
Os dois principais protocolos de melhores práticas para exploração mineral no mundo são aqueles estabelecidos pelo "The Joint Ore Reserves Committee of The Australasian Institute of Mining and Metallurgy" (JORC) e pelo "National Instrument 43-101" (NI 43-101). Além desses, é importante também destacar as diretrizes estabelecidas pelo "Committee for Mineral Reserves International Reporting Standards of the CIMM - International Council of Mining and Metals" (CRIRSCO). Por fim, cabe mencionar os esforços da Comissão Brasileira de Recursos e Reservas (CBRR) para estabelecer um código de melhores práticas padronizado para aplicação no Brasil.

O JORC, estabelecido na Austrália em 1971, elaborou o "Australasian Code for Reporting of Exploration Results, Mineral Resources and Ore Reserves" em 1989. Este documento define o padrão mínimo das práticas de exploração mineral e da elaboração de relatórios públicos de recursos minerais e reservas de minério na Austrália.

O CRIRSCO foi formado em 1994 como uma aliança informal de organizações nacionais de emissão de relatórios de exploração mineral. Nos últimos anos, essa aliança evoluiu para tornar-se um comitê reconhecido por organizações globais como o "International Accounting Standards Board" (IASB), a "United Nations Economic Commission for Europe" (UNECE) e o "International Council on Mining and Metals" (ICMM) como a instituição internacional que representa a indústria de mineração em questões relativas à elaboração de relatórios de ativos minerais. Em 2006, o CRIRSCO publicou a primeira versão do "CRIRSCO International Reporting Template".

A Comissão Brasileira de Recursos e Reservas (CBRR) foi estabelecida em 2015 através de um acordo entre a Associação Brasileira de Empresas de Pesquisa Mineral (ABPM), a Agência Brasileira de Desenvolvimento Tecnológico da Indústria Mineral (ADIMB) e o Instituto Brasileiro de Mineração (IBRAM). A CBRR foi o responsável pela elaboração do Guia para Declaração de Recursos e Reservas

Neste trabalho, as diretrizes utilizadas para avaliação das práticas de pesquisa mineral foram baseadas nas diretrizes do NI 43-101, que é o mais utilizado no Brasil. O NI 43-101, introduzido em 2001, é um instrumento normativo da Canadian Securities Administrators (CSA), órgão regulador das bolsas de valores canadenses, que define os padrões para relatórios de pesquisa mineral para os órgãos reguladores e os investidores. O “Exploration Best Practices Guidelines”, guia de melhores práticas de 
pesquisa mineral do NI 43-101, foi elaborado pelo CIM ("Canadian Mining, Metallurgy and Petroleum Association") e se tornou referência de qualidade ao redor do mundo.

O conjunto de orientações à melhores práticas para os programas de exploração mineral do CIM foi elaborado para garantir uma qualidade de trabalho consistentemente alta, assegurando a confiança do mercado e auxiliando os reguladores das bolsas de títulos mobiliários. As diretrizes foram preparadas para auxiliar a "Qualified Person”, ou Pessoa Qualificada, no planejamento e supervisão de programas de exploração mineral que serão relatados sob o NI 43-101.

A Pessoa Qualificada é definida no NI 43-101 como engenheiro (a) ou geocientista com pelo menos cinco anos de experiência em exploração mineral, planejamento de lavra, operação de mina, ou avaliação de projetos, com experiência relevante na área do projeto ou relatório, e membro de uma associação profissional reconhecida. Uma Pessoa Qualificada deve ser responsável pelo planejamento, execução e interpretação e geração de relatórios de todas as atividades de exploração. Os resultados devem ser apresentados em relatório técnico conforme formulário contido no NI 43-101.

A seguir, uma tradução simplificada das diretrizes contidas no NI 43-101 para cada etapa do processo de exploração mineral.

1) Uma Pessoa Qualificada deve planejar, implementar e supervisionar os trabalhos de exploração e garantir que as práticas seguidas são baseadas em critérios geralmente aceitos ou que podem ser justificadas tecnicamente.

2) As premissas geológicas em que os trabalhos de exploração são conduzidos devem incluir tipo de depósito, ambiente geológico e configuração da mineralização, e devem estar apoiadas por dados de campo e abordagem científica.

3) Devem ser implementados programas sistemáticos de garantia e controle de qualidade (QAQC - "Quality Assurance and Quality Control”) aplicados à aquisição de dados.

4) Os métodos aplicados e os dados obtidos devem ser devidamente registrados, documentados e localizados com precisão em escalas adequadas, e mantidos com segurança.

5) O planejamento da pesquisa, o mapeamento, a amostragem, a preparação das amostras, a segurança das amostras e as análises ou ensaios devem ser acompanhados de registro detalhado. Os procedimentos adotados e os resultados 
obtidos devem ser bem documentados e justificados. Um programa de verificação de dados deve ser implementado para confirmar a validade dos dados obtidos.

6) Os programas de amostragem devem ser executados com práticas de amostragem cientificamente estabelecidas, a fim de garantir que os resultados sejam representativos e confiáveis. Programas de controle de qualidade adequados devem ser planejados e implementados, e devem incluir medidas como amostras em branco, padrões e duplicadas.

7) O método de perfuração deve ser adequado ao material a ser investigado, o objetivo do programa e as condições dos locais de perfuração. Os ensaios devem ser realizados com a utilização de técnicas adequadas para a espessura, ângulo e comprimento dos furos. Uma fração representativa do material amostrado deve ser mantida. Os trabalhos devem ser registrados em software adequado para o tipo de perfuração, as particularidades geológicas, o tipo de mineralização e as condições geotécnicas. Qualquer informação geofísica ou outras tais pesquisas também devem registradas. Um registro fotográfico também é recomendado.

8) A segurança das amostras da coleta à análise é um componente vital no processo de amostragem. Devem ser estabelecidos procedimentos para garantir a segurança adequada da amostragem e dos locais de preparação e armazenamento das amostras, além do envio rápido, direto e seguro das amostras para os laboratórios.

9) A escolha dos procedimentos para preparação das amostras deve ser apropriada para o material a ser analisado.

10) Análise e testes das amostras devem ser realizados por laboratório de boa reputação. A seleção do laboratório e dos métodos analíticos deve ser documentada e justificada. Os resultados da análise e dos testes devem estar apresentados em certificados emitidos e assinados pelo laboratório, acompanhados pela descrição dos métodos utilizados. A confiabilidade dos resultados analíticos e dos testes deve ser medida através da comparação com os resultados das amostras de controle de qualidade. Deve-se realizar análises duplicadas em outros laboratórios.

11) A interpretação dos dados obtidos deve ser sistemática, contínua e completa, incluindo toda a informação obtida, e deve ser documentada. Deve-se avaliar com que solidez as informações obtidas na pesquisa suportam as conclusões qualitativas e quantitativas. 
12) A estimativa do recurso e da mineral e uma reserva mineral são as duas etapas fundamentais no desenvolvimento do projeto. Os métodos e parâmetros usados devem estar em conformidade com os princípios geralmente aceitados no Canadá e devem ser apresentados e justificados com a estimativa. Um recurso mineral pode ser estimado para onde há potencial para produção mineral com lucro. Reservas podem ser estimadas quando um estudo de pré-viabilidade ou viabilidade, conforme definido pelo NI 43-101, indica que esses recursos podem ser produzidos com lucro.

13) Todos os trabalhos de campo devem ser conduzidos de forma segura e profissional com relação ao meio ambiente, às comunidades locais e com os requisitos normativos. Um programa ambiental adequado deve ser executado.

14) A interpretação e avaliação dos resultados ao final de cada fase devem determinar se os objetivos do programa foram alcançados e se a continuação dos trabalhos é justificável. Qualquer plano de trabalho adicional de exploração deve identificar metas, recomendar um programa, e apresentar orçamento e cronograma.

15) Ao final de cada fase do projeto, o QP deve elaborar e assinar um amplo relatório técnico conforme o formato apresentado no formulário 1 do NI 43-101.

\subsection{A Pequena MineraçÃo}

Para Hentschel et al. (2002), a mineração artesanal ou em pequena escala se refere, em geral, à mineração praticada por indivíduos, grupos, famílias ou cooperativas, com pouca ou nenhuma mecanização, frequentemente de maneira ilegal. Em alguns países, é feita uma distinção entre mineração artesanal, ou garimpo, que é puramente manual, e mineração de pequena escala, mais mecanizada e em maior escala. Em alguns países da África Ocidental (Mali, Níger e Burkina Faso), mineração de pequena escala é diferenciada da mineração artesanal pela presença permanente de instalações uma vez confirmada a existência de um corpo de minério.

Buxton (2013) estima que de 20 a 30 milhões de pessoas trabalham neste setor em mais de 80 países. Buxton destaca que há considerável diversidade de escala, de mineração rudimentar, com picaretas e pás, para mineração de pequena escala, com máquinas simples. Villegas et al. (2012) inferem que o setor produz cerca de $10 \%$ do 
ouro, de 15 a 20\% dos diamantes, de 25 a 30\% do estanho, e $80 \%$ por cento das pedras preciosas do mundo.

No Brasil, o DNPM (Departamento Nacional de Pesquisa Mineral do Ministério das Minas e Energia) usa como critério para definir mineração em pequena escala aquela que produz entre 10.000 e 100.000 toneladas de minério por ano (CPRM, 2002). Pode-se também utilizar o critério utilizado para emissão da licença ambiental simplificada para a atividade de mineração, limitada a 50.000 toneladas por ano.

Segundo Seccatore et al. (2015), a pequena mineração oferece maior flexibilidade operacional e mercadológica em relação à grande mineração, e pode operar eficientemente com teores minerais baixos e flutuações do mercado. Os autores preveem, portanto, um crescimento da participação da pequena mineração na produção de metais preciosos nas próximas décadas.

\subsection{Melhores Práticas de Pesquisa na Pequena Mineração}

Seccatore et al. (2014) propõem uma abordagem para a pesquisa mineral na pequena mineração diferente daquela da mineração de grande porte. Na visão dos autores, a atratividade para o investimento na pequena mineração encontra-se apenas em provar, na fase inicial do negócio, uma reserva mineral mínima suficiente para possibilitar o retorno rápido do investimento. Introduzem os conceitos de "reserva mínima" e "replicação", e uma metodologia prática para a medição da reserva provada mínima. De acordo com a metodologia proposta, parte dos lucros da operação na reserva mínima deve ser reinvestida na pesquisa mineral, replicando-se quantas vezes forem necessárias a medição de reserva mínima para continuidade da produção mineral. Ao aplicar essa metodologia em uma operação garimpeira de ouro no Equador, os autores mostram como a comprovação de uma reserva mínima de 1/1.000 em relação ao que seria satisfatório para grandes mineradores já se mostrou suficiente para viabilizar a operação.

Tichauer et al. (2015) registram que o processo de cálculo de reservas, especialmente devido ao alto custo e tempo necessário para campanhas de perfuração de diamante pode ser caro e demorado, é muitas vezes proibitivo na mineração em pequena escala. Apresentam uma metodologia para minimizar o custo de exploração mineral na pequena mineração através do uso de técnicas de 
Geofísica, com o objetivo de gerar um plano de sondagem econômico e eficiente. Por fim, demonstram como a metodologia foi aplicada e avaliada em um pequeno depósito de manganês no estado de São Paulo, Brasil.

\subsection{Pesquisa em Depósitos de Manganês}

Dos três casos de pesquisa mineral analisados neste trabalho, os dois em que houve atividade relevante ocorreram em depósitos de manganês. Merece algumas considerações, portanto, a crescente utilização de métodos geofísicos para a identificação da ocorrência e da extensão de depósitos de manganês.

Segundo Ramazi e Mostafaie (2013), a pesquisa de manganês, especialmente em depósitos sedimentares, envolve vários problemas. Como o comportamento do manganês é distinto em diferentes ambientes geoquímicos, a aplicação de métodos geoquímicos tem muitas limitações. Por outro lado, não há um método geofísico padrão para depósitos de manganês. A integração de métodos geofísicos tem sido uma prática comum na exploração mineral. A seleção dos métodos geofísicos a serem aplicados em um depósito mineral depende das propriedades físicas do alvo e das rochas encaixantes, da configuração geológica e da topografia.

Ramazi e Mostafaie demonstram como no depósito de manganês de Marand, Irã, devido às propriedades físicas do alvo e das rochas encaixantes, ao ambiente geológico, e à baixa resistividade dos corpos minerais, foi aplicada uma integração dos métodos geoelétricos de potencial espontâneo, de polarização induzida, e de resistividade. Concluem que a integração de métodos produz resultados muito melhores, especialmente nos veios mineralizados com alta inclinação. Além disso, perceberam um erro de leitura muito menor, especialmente na identificação de anomalias mais profundas.

Kita et al. (2012) mostram como métodos eletromagnéticos aéreos têm sido utilizados para a exploração do manganês em partes de Pilbara, Austrália, desde 2002. Os resultados obtidos com os ensaios sobre as áreas de depósitos de minério de manganês conhecidos revelaram uma boa correlação entre os condutores eletromagnéticos e as zonas de manganês. Os ensaios revelaram novas zonas de condutividade em áreas onde ocorrências de manganês haviam sido encontradas, mas que ainda não haviam sido perfuradas. Em 2010, a pesquisa mapeou com 
sucesso a extensão das zonas de manganês conhecidas e proporcionou a identificação e mapeamento de vários novos alvos. Esses novos alvos foram posteriormente perfurados, e a ocorrência de óxido de manganês foi comprovada. $A$ forma da anomalia eletromagnética mapeia o contorno do recurso e a força do sinal eletromagnético tem forte correlação com o teor do recurso.

Em resumo, métodos geofísicos têm sido cada vez mais utilizados na pesquisa em depósitos de manganês, na medida em produzem bons resultados na identificação de corpos mineralizados e da extensão desses corpos.

\subsection{MATRIZ DE PRIORIZAÇÃO}

\subsubsection{Definição de Matriz de Priorizaçâo}

Arruda (2015) explica que a Matriz de Priorização é uma ferramenta para tomada de decisão, já que estabelece a priorização de fatores-chave, problemas a serem resolvidos e processos a serem implementados nas organizações. Menciona o autor que a Matriz de Priorização mais conhecida é a Matriz GUT, considerada uma ferramenta de gestão para identificar, observar, analisar e buscar soluções para os problemas e desafios em uma organização. A Matriz GUT estabelece a priorização baseada nos fatores de Gravidade, Urgência e Tendência, e consiste em uma tabela de pontuação, onde pode-se visualizar quais itens tem maior prioridade em relação aos demais.

\subsubsection{A Matriz de Priorização CEB}

Arruda (2015) apresenta a Matriz de Priorização CEB, que leva em consideração metodologia da Matriz GUT mas utiliza critérios de priorização em função da conjuntura do mercado econômico. Essa matriz prioriza as atividades em função da correlação direta entre custo e benefício, necessária para análise do projeto antes de sua implementação. A Matriz de Priorização CEB, ilustrada na figura 1, utiliza os seguintes critérios de priorização: 
C - Custo $\rightarrow$ Quanto vai custar para implementar. Quanto menor melhor.

E - Esforço $\rightarrow$ Esforço necessário para implementar. Quanto menor melhor.

B - Benefícios $\rightarrow$ Quanto vamos receber ao implementar. Quanto maior melhor.

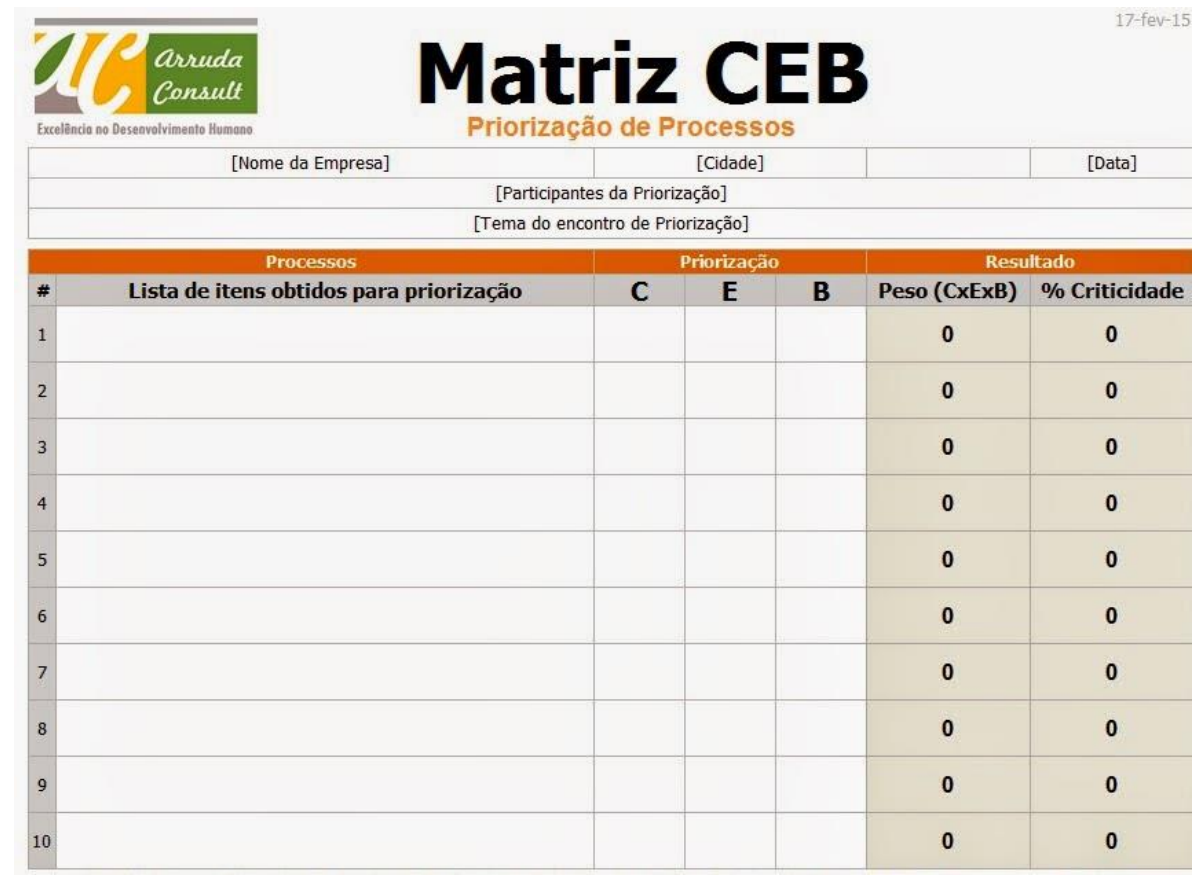

Figura 1 - Matriz de Priorização CEB (Arruda, 2015).

Arruda destaca que a grande vantagem de utilizar a Matriz CEB é que ela auxilia o gestor a avaliar de forma quantitativa os problemas da empresa, tornando possível priorizar as ações corretivas e preventivas para o solucionar totalmente ou parcialmente o problema.

A construção da Matriz de Priorização CEB inclui:

1. Listar os problemas, atividades, processos, ideias, soluções ou projetos;

2. Classificar toda a lista conforme os critérios de priorização CEB;

3. Verificar a coluna "Peso (CxExB)", que produz resultados da multiplicação das notas de cada um dos fatores CEB;

4. Verificar a coluna "\% de Criticidade", que calcula os valores obtidos para cada problema ou atividade listada;

5. Visualizar os itens de maior relevância e traçar um plano de ação para monitoramento e implementação dos itens priorizados. 


\section{MATERIAIS E MÉTODOS}

\subsection{A MATRIZ CEBIM}

A Matriz CEBIm é uma ferramenta para avaliação da aderência da pesquisa mineral conduzida em um projeto às melhores práticas de pesquisa mineral. Por ter sido concebida para ser simples, prática, rápida, econômica e eficaz, essa ferramenta é adequada para avaliação e condução de pesquisa mineral na mineração em pequena escala.

Os critérios da Matriz CEBIm são os mesmos da Matriz CEB - custo, esforço e benefício, acrescidos do nível de implementação da atividade ou prática na pesquisa mineral (Im).

O objetivo da Matriz CEBIm é o de possibilitar a avaliação do nível de aderência entre a pesquisa mineral conduzida em um projeto de mineração e as melhores práticas de pesquisa mineral através do "índice CEBIm", que varia de 2 a 10 . Um índice 10 significa que a pesquisa mineral foi conduzida com total aderência às melhores práticas, com todas as atividades bem implementadas, e que o resultado é muito confiável. O índice 2 é o mínimo possível, indicando absoluta inobservância às melhores práticas, e representa apenas o conhecimento mínimo existente para justificar a manutenção dos direitos minerários pelo titular, como conhecimento básico de geologia regional e local, evidências antigos trabalhos de lavra, ou mesmo atividades de pesquisa realizadas de forma precária, com resultado não confiável e insignificante. A Matriz CEBIm pode ser utilizada para avaliação e condução de pesquisa mineral durante toda a vida útil do projeto de produção mineral.

As atividades avaliadas são baseadas nas diretrizes de melhores práticas na pesquisa mineral estabelecidas pelo NI 43-101. Como algumas das práticas do NI 43101 são dependentes de outras, as 15 diretrizes existentes foram condensadas em 10.

Os pesos para o custo, o esforço e o benefício foram pré-estabelecidos para cada diretriz de melhores práticas da Matriz CEBIm.

Os pesos de custo (C) para cada diretriz foram definidos em números inteiros de 1 a 5, peso 1 para as diretrizes mais dispendiosas e 5 para as menos dispendiosas. 
Os pesos de esforço (E) para cada diretriz foram definidos em números inteiros de 1 a 5, peso 1 para as diretrizes que demandam maior esforço e 5 para as que demandam menor esforço.

Os pesos de benefício (B) para cada diretriz foram definidos em números inteiros de 1 a 5 , peso 1 para as diretrizes que proporcionam menor benefício e 25 para as que proporcionam maior benefício.

Assim, o benefício tem o peso máximo (25) igual ao máximo acumulado pelo custo e pelo esforço $(5 \times 5)$, e a distribuição de pesos pode ser feita de forma equilibrada entre os aspectos positivos (benefício) e os de caráter negativo (custo $\mathrm{x}$ esforço).

Os pesos para custo (C), esforço (E) e benefício (B) em cada uma das 10 diretrizes da Matriz CEBIm foram pré-estabelecidos conforme a tabela 1. 
Tabela 1 - Pesos de custo (C), esforço (E) e benefício (B) para melhores práticas em pesquisa mineral.

\begin{tabular}{|l|l|l|l|}
\hline \multicolumn{1}{|l|}{ 1. Pesquisa projetada e conduzida por Pessoa Qualificada (QP) } \\
\hline Critério & Peso & Justificativa \\
\hline C & 3 & O(a) QP é bem remunerado(a), mas para a pesquisa o custo é relativamente baixo. \\
E & 4 & Esforço para encontrar, contratar e manter um(a) QP é relativamente baixo. \\
B & 25 & Os benefícios são os maiores possíveis, pela qualidade do trabalho e reputação profissional. \\
\hline 2. Premissas geológicas apoiadas por dados de campo e abordagem científica \\
\hline Critério & Peso & Justificativa \\
\hline C & 4 & Atividades de custo relativamente baixo como reconhecimento de campo e análise bibliográfica. \\
E & 4 & O esforço se limita à preparação do campo especialmente acessos. \\
B & 25 & O entendimento do ambiente geológico é fundamental na pesquisa mineral. \\
\hline 3. Programa de controle de qualidade aplicado à aquisição de dados \\
\hline Critério & Peso & Justificativa \\
\hline C & 4 & Custo de implementar o sistema. \\
E & 4 & Esforço de gerenciar o controle. \\
B & 25 & A segurança das informações é importante, mas com peso mais baixo do que outras atividades. \\
\hline
\end{tabular}

4. Métodos aplicados e os dados obtidos devidamente registrados

\begin{tabular}{|l|l|l|}
\hline Critério & Peso & Justificativa \\
\hline C & 4 & Custo de gerenciar as atividades. \\
E & 4 & Esforço de disciplina administrativa. \\
B & 25 & O registro adequado dos métodos e dados é fundamental para a qualidade do trabalho. \\
\hline
\end{tabular}

\begin{tabular}{|l|l|l|}
\hline \multicolumn{3}{|c|}{ 5. Amostragem realizada com base científica } \\
\hline Critério & Peso & Justificativa \\
\hline C & 2 & Depende da execução adequada de furos, poços e/ou trincheiras. \\
E & 2 & É necessário um esforço especial para que a amostraragem seja efetuada adequadamente. \\
B & 25 & Amostragem representativa é primordial na pesquisa mineral. \\
\hline
\end{tabular}
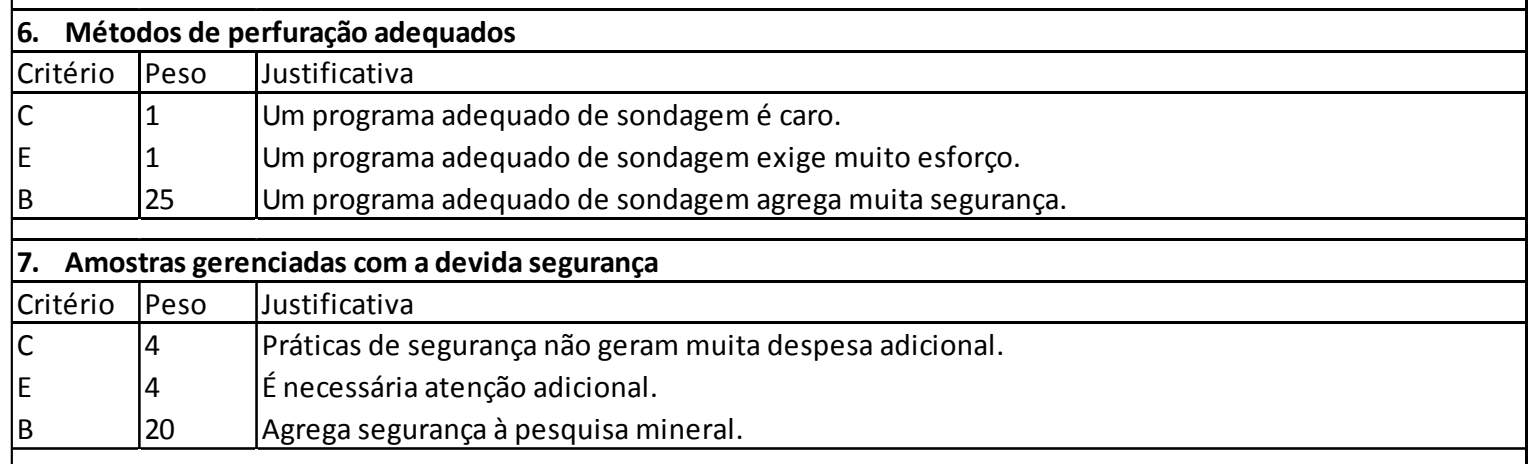

\begin{tabular}{|l|l|l|}
\hline \multicolumn{3}{|c|}{ 8. Preparação das amostras adequada } \\
\hline Critério & Peso & Justificativa \\
\hline C & 4 & Custo adicional relativamente pequeno. \\
E & 3 & É necessária atenção e disciplina especial com todas as amostras. \\
B & 20 & A preparação das amostras é importante para boa análise dos teores. \\
\hline
\end{tabular}

\begin{tabular}{|l|l|l|}
\hline \multicolumn{3}{|c|}{ 9. Análise das amostras realizada por laboratório de boa reputação } \\
\hline Critério & Peso & Justificativa \\
\hline C & 4 & O custo das análises pode aumentar. \\
E & 4 & O esforço de gerenciar pode ser maior. \\
B & 20 & A reputação do labnoratório agrega considerável segurança e valor à pesquisa mineral. \\
\hline
\end{tabular}

\begin{tabular}{|l|l|l|}
\hline \multicolumn{3}{|l|}{ 10. Trabalhos conduzidos com enquadramento aos requisitos normativos } \\
\hline Critério & Peso & Justificativa \\
\hline C & 3 & Adequação às normas agrega custos e despesas. \\
E & 2 & É necessário um esforço significativo para que as normas sejam seguidas. \\
B & 20 & Adequação às normas evita passivos e aumenta o valor ao projeto. \\
\hline
\end{tabular}


No modelo proposto, a coluna "\% de Criticidade" da Matriz CEB foi substituída por uma coluna para determinação do nível de implementação em cada uma das 10 diretrizes de melhores práticas na pesquisa mineral (“Im”). O avaliador deve inserir uma nota que representa uma estimativa do nível de implementação em cada uma das 10 diretrizes. A inserção dessas notas para cada diretriz resulta no índice CEBIm. O índice CEBIm mede, em uma escala de 0 a 10, o nível de aderência da pesquisa mineral de um projeto à melhores práticas, e varia de 2 (nenhuma aderência) a 10 (total aderência). A Figura 2 ilustra a Matriz CEBIm com os pesos pré-estabelecidos para custo $(C)$, esforço $(E)$ e benefício $(B)$ em cada uma das 10 diretrizes, sem as notas que devem ser inseridas pelo avaliador para obtenção do índice CEBIm.

\begin{tabular}{|c|c|c|c|c|c|c|c|}
\hline & \multicolumn{2}{|c|}{$\begin{array}{l}\text { Pesos pré-estabelecidos } \\
\text { para pesquisa mineral. }\end{array}$} & \multicolumn{5}{|c|}{$\begin{array}{c}\text { Notas } 1,3,4 \text { ou } 5 \text { para o nível de } \\
\text { implementação das diretrizes para } \\
\text { pesquisa mineral. }\end{array}$} \\
\hline & & 4 & $\triangle$ & 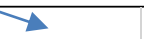 & & 4 & \\
\hline \multicolumn{2}{|c|}{ Projeto } & Custo (C) & Esforço (E) & Benefício (B) & CEB & Impl. (Im) & Índice \\
\hline & & máxC $=1$ & máxE = 1 & máxB = 25 & máx $=625$ & $>80 \%=5$ & CEBIm \\
\hline \multicolumn{2}{|c|}{ Diretrizes } & mínC = 5 & mínE = 5 & mínB = 5 & mín=5 & $<20 \%=1$ & $(2-10)$ \\
\hline 1 & Pesquisa planejada e conduzida por Pessoa Qualificada & 3 & 4 & 25 & 300 & & 0,0 \\
\hline 2 & Premissas geológicas apoiadas por dados de campo e abordagem científica & 4 & 4 & 25 & 400 & & 0,0 \\
\hline 3 & Programa de controle de qualidade aplicado à aquisição de dados & 4 & 4 & 25 & 400 & & 0,0 \\
\hline 4 & Métodos aplicados e os dados obtidos devidamente registrados & 4 & 4 & 25 & 400 & & 0,0 \\
\hline 5 & Amostragem realizada com base científica & 2 & 2 & 25 & 100 & & 0,0 \\
\hline 6 & Métodos de perfuração adequados & 1 & 1 & 25 & 25 & & 0,0 \\
\hline 7 & Amostras gerenciadas com a devida segurança & 4 & 4 & 20 & 320 & & 0,0 \\
\hline 8 & Preparação das amostras adequada & 4 & 3 & 20 & 240 & & 0,0 \\
\hline 9 & Análise das amostras realizada por laboratório de boa reputação & 4 & 4 & 20 & 320 & & 0,0 \\
\hline 10 & Trabalhos conduzidos com enquadramento aos requisitos normativos & 3 & 2 & 20 & 120 & & 2,0 \\
\hline & & & & & & & 0,0 \\
\hline & & & & & & & \\
\hline
\end{tabular}

Figura 2 - Matriz de Priorização CEBIm para programas de pesquisa mineral.

Para que o índice CEBIm seja consistente, é importante que parâmetros sejam estabelecidos para aplicação das notas de nível de implementação para as 10 diretrizes de melhores práticas em pesquisa mineral da Matriz CEBIm. A nota do nível de implementação para cada diretriz deve ser um número inteiro de 1 a 5 . Em geral, nota 1 significa que a diretriz não foi implementada ou que foi adotada em até $20 \%$, e nota 5 significa que a diretriz foi implementada adequadamente, em nível superior a 80\%. A tabela 2 abaixo destaca os critérios a serem considerados na aplicação das notas de nível de implementação em cada diretriz da Matriz CEBIm. 
Tabela 2 - Critérios para aplicação das notas na Matriz CEBIm. Diretriz 1: Pesquisa mineral planejada e conduzida por Pessoa Qualificada (QP)

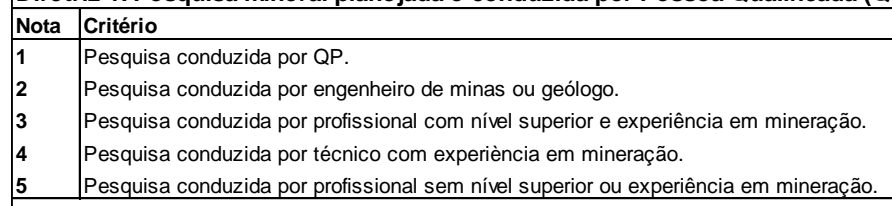

\begin{tabular}{|l|l|l|}
\hline \multicolumn{2}{|c|}{ Diretriz 2: Premissas geológicas apoiadas por dados de campo e abordagem científica } \\
\hline Nota & Implementação & Critério \\
\hline $\mathbf{1}$ & Até $20 \%$ & Qualidade e abrangência do mapeamento geológico. \\
$\mathbf{2}$ & Acima de $20 \%$ até $40 \%$ & Qualidade e abrangência do mapeamento geológico. \\
$\mathbf{3}$ & Acima de $40 \%$ até $60 \%$ & Qualidade e abrangência do mapeamento geológico. \\
$\mathbf{4}$ & Acima de $60 \%$ até $80 \%$ & Qualidade e abrangência do mapeamento geológico. \\
$\mathbf{5}$ & Acima de $80 \%$ até 100\% & Qualidade e abrangência do mapeamento geológico. \\
\hline
\end{tabular}

Diretriz 3: Programa de controle de qualidade aplicado à aquisição de dados

\begin{tabular}{|l|l|l|}
\hline Nota & Implementação & Critério \\
\hline $\mathbf{1}$ & Até $20 \%$ & Abrangência e gerenciamento do controle de qualidade. \\
$\mathbf{2}$ & Acima de $20 \%$ até $40 \%$ & Abrangência e gerenciamento do controle de qualidade. \\
$\mathbf{3}$ & Acima de $40 \%$ até $60 \%$ & Abrangência e gerenciamento do controle de qualidade. \\
$\mathbf{4}$ & Acima de $60 \%$ até $80 \%$ & Abrangência e gerenciamento do controle de qualidade. \\
$\mathbf{5}$ & Acima de $80 \%$ até 100\% & Abrangência e gerenciamento do controle de qualidade. \\
\hline
\end{tabular}

Diretriz 4: Métodos aplicados e dados obtidos devidamente registrados

\begin{tabular}{|l|l|l|}
\hline Nota & Implementação & Critério \\
\hline 1 & Até $20 \%$ & Abrangência precisão e organização dos registros.
\end{tabular}

\begin{tabular}{|l|l|l|}
\hline $\mathbf{1}$ & Até $20 \%$ & Abrangência, precisão e organização dos registros.
\end{tabular}

2 Acima de $20 \%$ até $40 \%$ Abrangência, precisão e organização dos registros.

3 Acima de $40 \%$ até $60 \%$ Abrangência, precisão e organização dos registros.

4 Acima de $60 \%$ até $80 \%$ Abrangência, precisão e organização dos registros.

5 Acima de $80 \%$ até $100 \%$ Abrangência, precisão e organização dos registros.

Diretriz 5: Amostragem realizada com base científica

\begin{tabular}{|c|c|c|}
\hline Nota & Implementação & Critério \\
\hline 1 & Até $20 \%$ & Abrangência e qualidade da amostragem. \\
\hline 2 & Acima de $20 \%$ até $40 \%$ & Abrangência e qualidade da amostragem. \\
\hline 3 & Acima de $40 \%$ até $60 \%$ & Abrangência e qualidade da amostragem. \\
\hline 4 & Acima de $60 \%$ até $80 \%$ & Abrangência e qualidade da amostragem. \\
\hline 5 & Acima de $80 \%$ até $100 \%$ & Abrangência e qualidade da amostragem. \\
\hline \multicolumn{3}{|c|}{ Diretriz 6: Métodos de perfuração adequados } \\
\hline Nota & Implementação & Critério \\
\hline 1 & Até $20 \%$ & Abrangência e adequação dos métodos de perfuração. \\
\hline 2 & Acima de $20 \%$ até $40 \%$ & Abrangência e adequação dos métodos de perfuração. \\
\hline 3 & Acima de $40 \%$ até $60 \%$ & Abrangência e adequação dos métodos de perfuração. \\
\hline 4 & Acima de $60 \%$ até $80 \%$ & Abrangência e adequação dos métodos de perfuração. \\
\hline 5 & Acima de $80 \%$ até $100 \%$ & Abrangência e adequação dos métodos de perfuração. \\
\hline \multicolumn{3}{|c|}{ Diretriz 7: Amostras gerenciadas com a devida segurança } \\
\hline Nota & Implementação & Critério \\
\hline 1 & Até $20 \%$ & Controle de segurança das amostras. \\
\hline 2 & Acima de $20 \%$ até $40 \%$ & Controle de segurança das amostras. \\
\hline 3 & Acima de $40 \%$ até $60 \%$ & Controle de segurança das amostras. \\
\hline 4 & Acima de $60 \%$ até $80 \%$ & Controle de segurança das amostras. \\
\hline 5 & Acima de $80 \%$ até $100 \%$ & Controle de segurança das amostras. \\
\hline \multicolumn{3}{|c|}{ Diretriz 8: Preparação das amostras adequada } \\
\hline Nota & Implementação & Critério \\
\hline 1 & Até $20 \%$ & Preparação adequada das amostras. \\
\hline 2 & Acima de $20 \%$ até $40 \%$ & Preparação adequada das amostras. \\
\hline 3 & Acima de $40 \%$ até $60 \%$ & Preparação adequada das amostras. \\
\hline 4 & Acima de $60 \%$ até $80 \%$ & Preparação adequada das amostras. \\
\hline 5 & Acima de $80 \%$ até $100 \%$ & Preparação adequada das amostras. \\
\hline \multicolumn{3}{|c|}{ Diretriz 9: Análise das amostras realizada por laboratório de boa reputação } \\
\hline Nota & Implementação & Critério \\
\hline 1 & Até 20\% & Amostras analisadas por laboratório de boa reputação. \\
\hline 2 & Acima de $20 \%$ até $40 \%$ & Amostras analisadas por laboratório de boa reputação. \\
\hline 3 & Acima de $40 \%$ até $60 \%$ & Amostras analisadas por laboratório de boa reputação. \\
\hline 4 & Acima de $60 \%$ até $80 \%$ & Amostras analisadas por laboratório de boa reputação. \\
\hline 5 & Acima de $80 \%$ até $100 \%$ & Amostras analisadas por laboratório de boa reputação. \\
\hline \multicolumn{3}{|c|}{ Diretriz 10: Trabalhos conduzidos com enquadramento aos requisitos normativos } \\
\hline Nota & Implementação & Critério \\
\hline 1 & Até 20\% & Observância aos requerimentos legais. \\
\hline 2 & Acima de $20 \%$ até $40 \%$ & Observância aos requerimentos legais. \\
\hline 3 & Acima de $40 \%$ até $60 \%$ & Observância aos requerimentos legais. \\
\hline 4 & Acima de $60 \%$ até $80 \%$ & Observância aos requerimentos legais. \\
\hline & Acima de $80 \%$ até $100 \%$ & Observância aos requerimentos legais. \\
\hline
\end{tabular}




\subsection{APLICAÇÃo I: GARIMPO dE OURO EM ITAITUBA, PA}

\subsubsection{Diagnóstico}

O Núcleo de Apoio à Mineração Responsável da USP - NAP.Mineração/USP enviou uma expedição a um garimpo de ouro em Itaituba, PA, em setembro de 2014. Tratava-se de uma tentativa dos empreendedores de retomar uma atividade de lavra garimpeira que havia resultado na produção de cerca de $55 \mathrm{~kg}$ de ouro entre $2001 \mathrm{e}$ 2002. A equipe do NAP coletou dados e elaborou um diagnóstico das condições do empreendimento, em que ficou evidente a magnitude dos riscos aos quais a atividade estava exposta.

Foram realizadas medição de coordenadas e altitudes, identificação das instalações e dos equipamentos, análise de logística e serviços, avaliação da rota de processamento mineral, coleta de amostras do ciclo da alimentação e dos rejeitos, registro fotográfico do sítio, das instalações e dos equipamentos, obtenção de informações sobre refino e comercialização do produto, verificação da situação da área junto ao DNPM, e avaliação de um relatório geológico incompleto, elaborado por um grupo que iniciou um plano de sondagem para possível aquisição da área, mas que abandonou o projeto.

A planta de beneficiamento estava equipada com gerador à diesel de 100kVA, guincho, britador de mandíbulas, moinho de martelos, placa de cobre e bombas para drenar a água da cava. O transporte era realizado por "voadeira" - pequeno barco a motor para navegação nos rios, e quadriciclo, para transporte em trilha dentro da área do garimpo. As instalações do acampamento incluíam com gerador independente, oficina, cabanas com função de dormitório e paiol, cozinha/refeitório, poço de água, e "banheiro".

Os principais riscos identificados foram o pouco conhecimento geológico, a fragilidade legal da área, a possibilidade de deslizamento, a falta de equipamentos de lavra, de beneficiamento e de segurança adequados, explosivos com data de validade vencida e a predominância de uma cultura de garimpo tradicional e não sustentável.

As Figuras 3 a 8 ilustram as condições precários do empreendimento. 


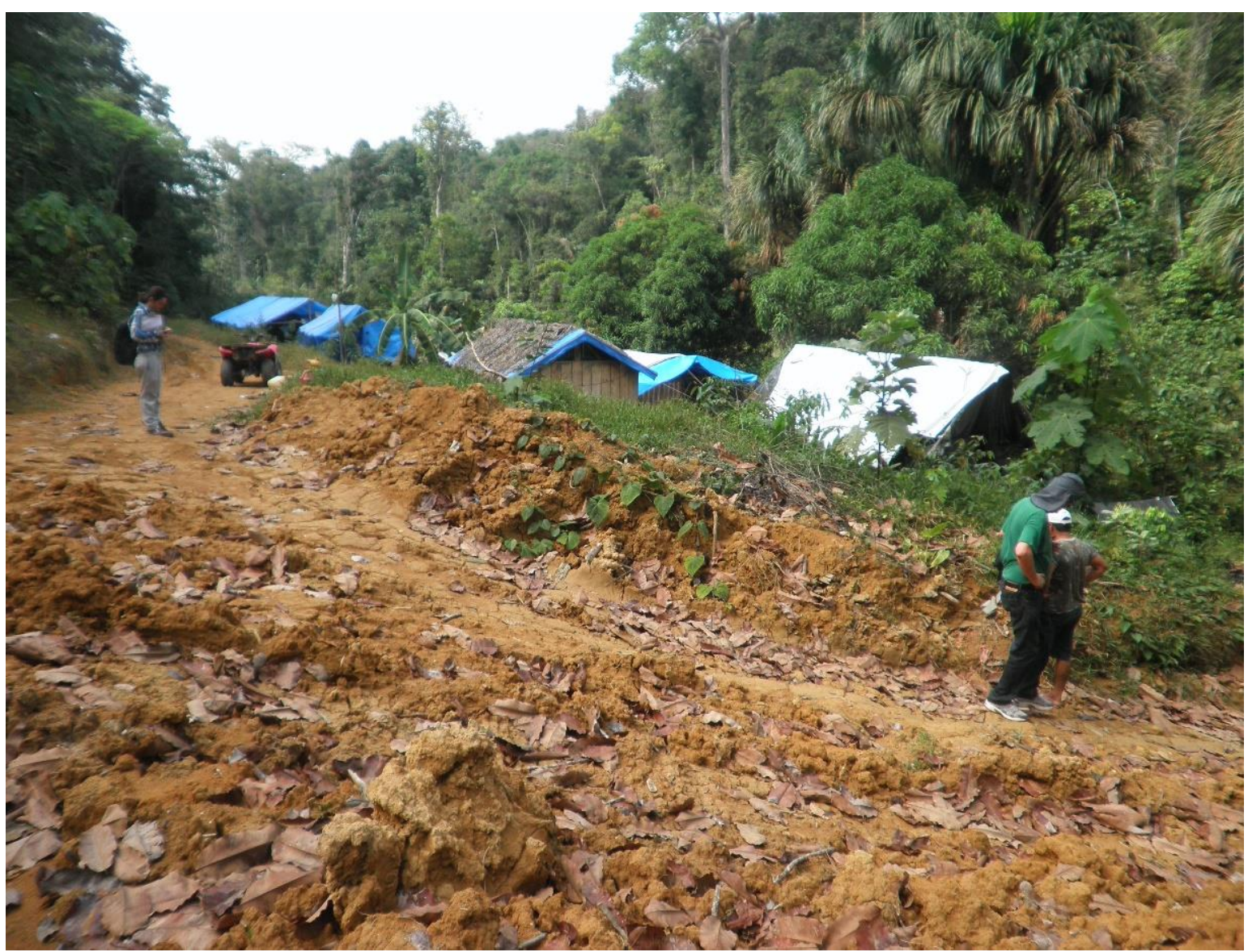

Figura 3 - Acampamento.

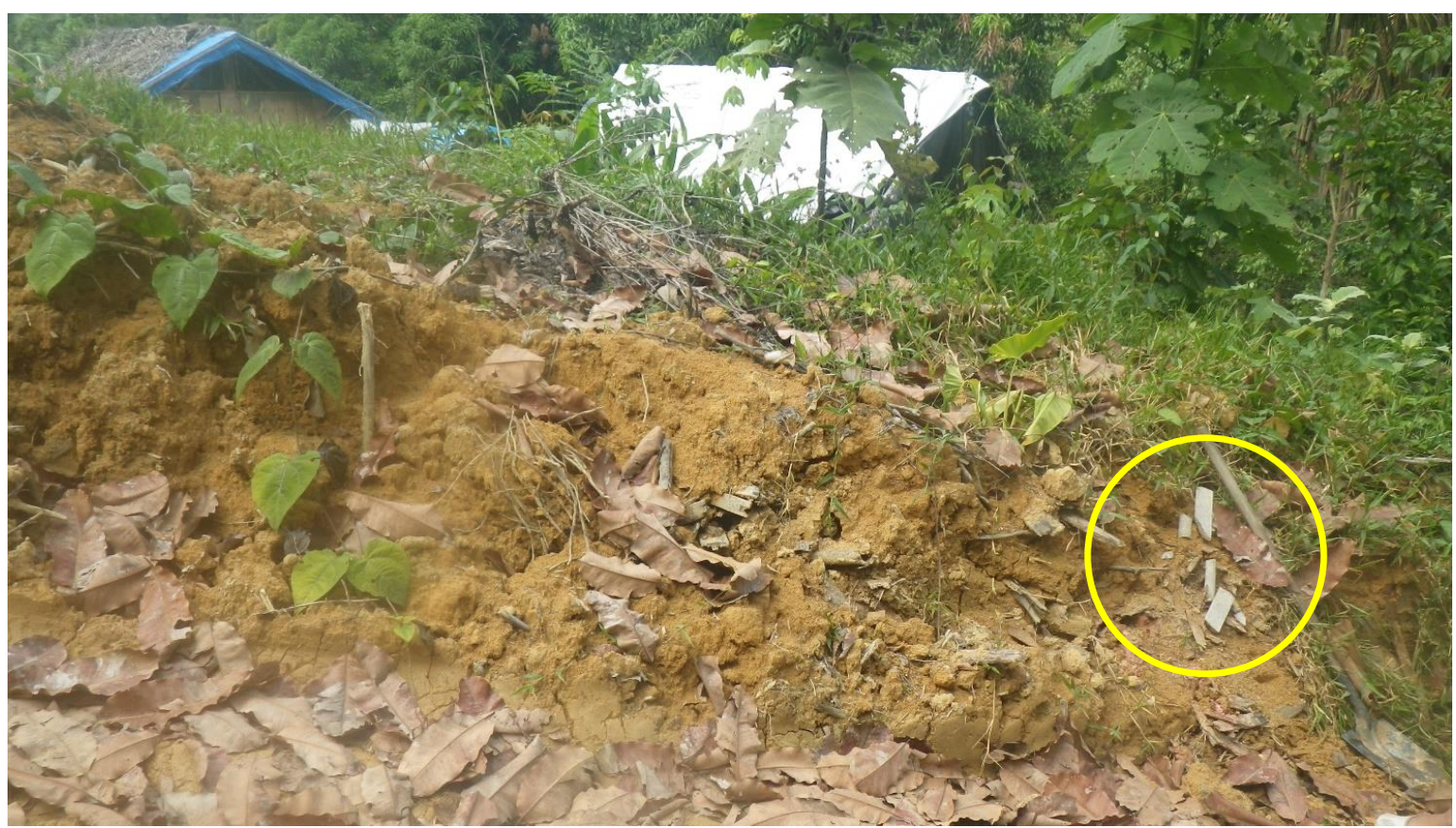

Figura 4 - Testemunhos de sondagem soterrados entre a trilha e o acampamento. 


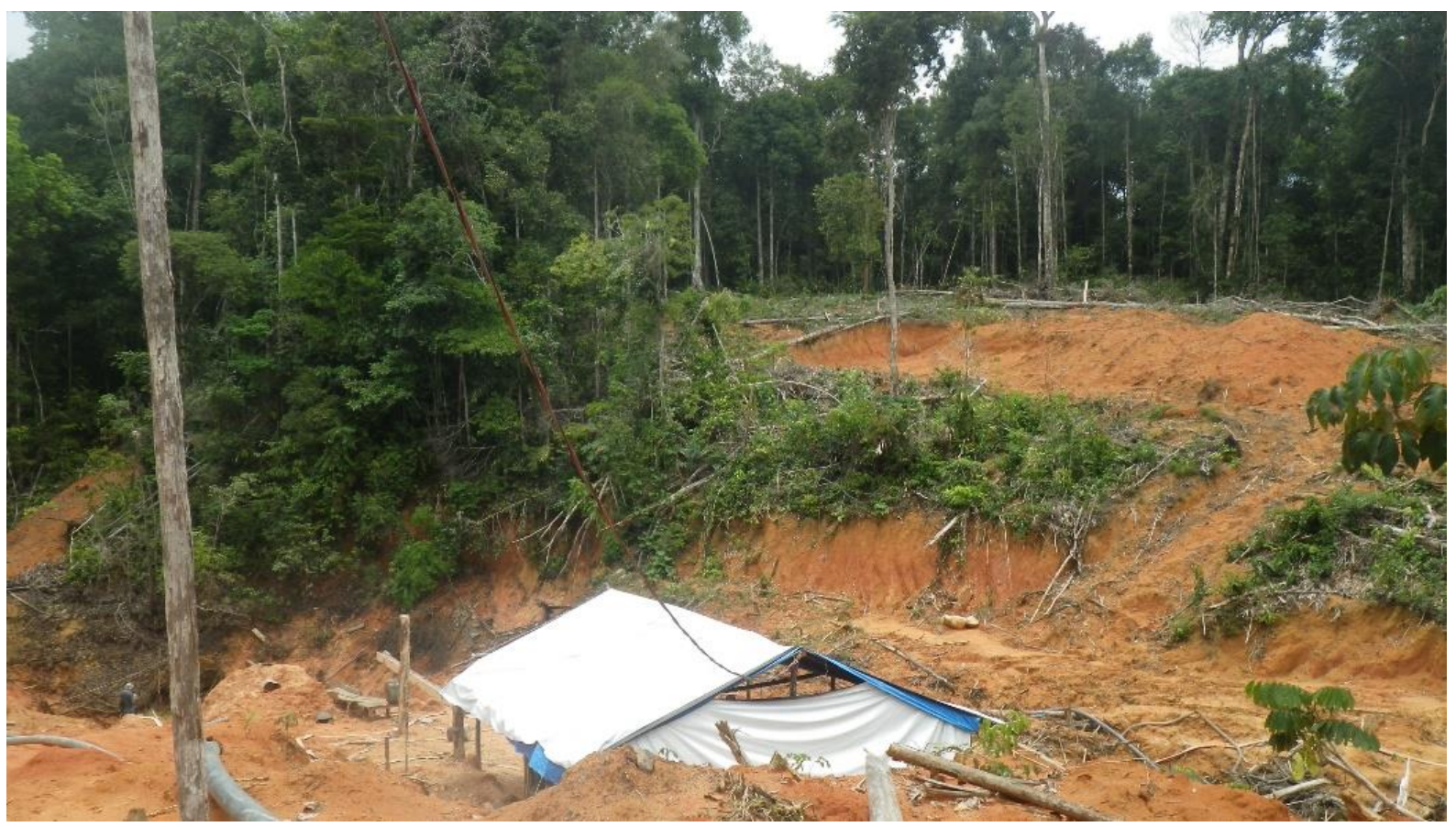

Figura 5 - Na frente a estrutura de beneficiamento, ao fundo a cava.

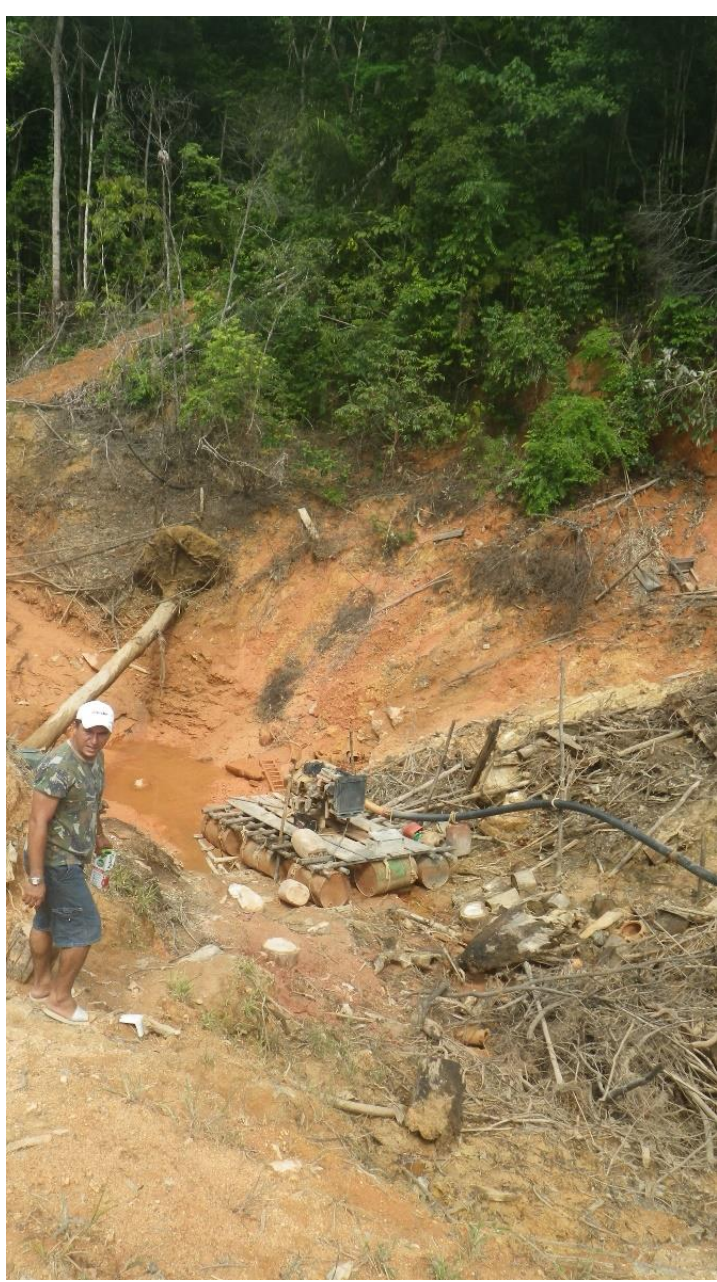

Figura 6 - Cava.

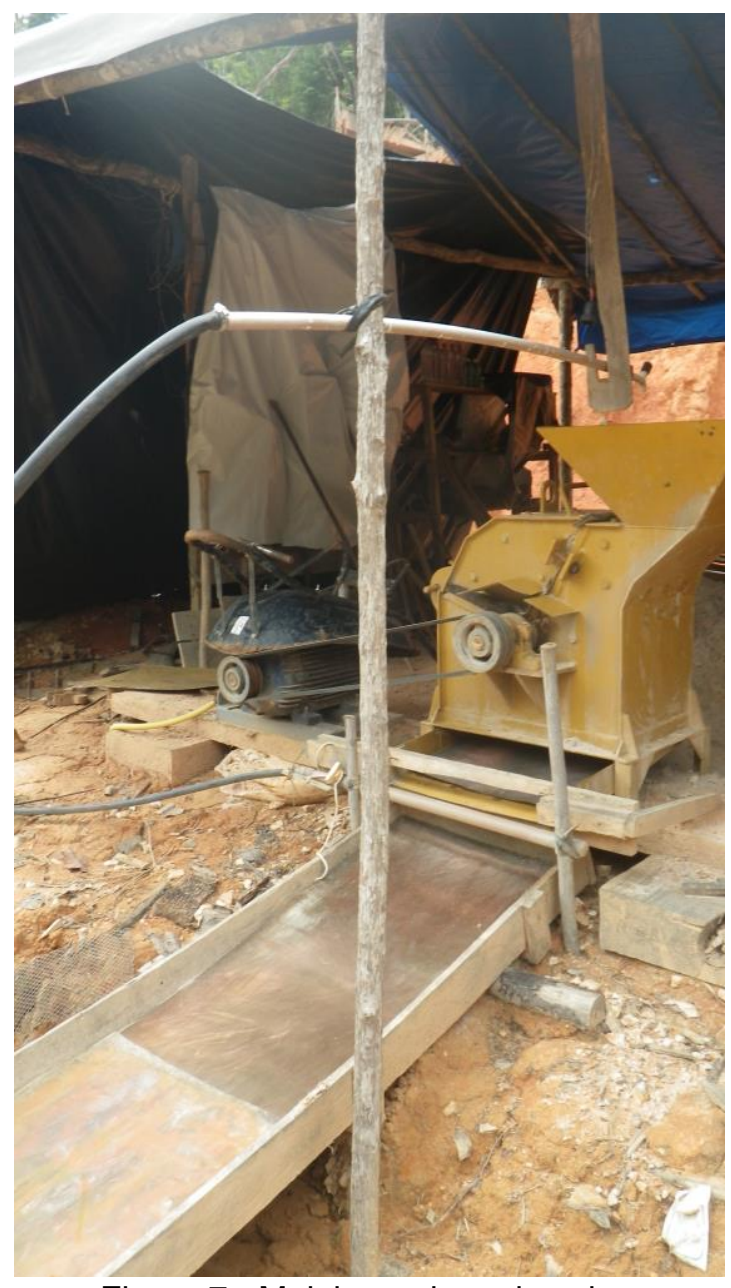

Figura 7 - Moinho e placa de cobre. 


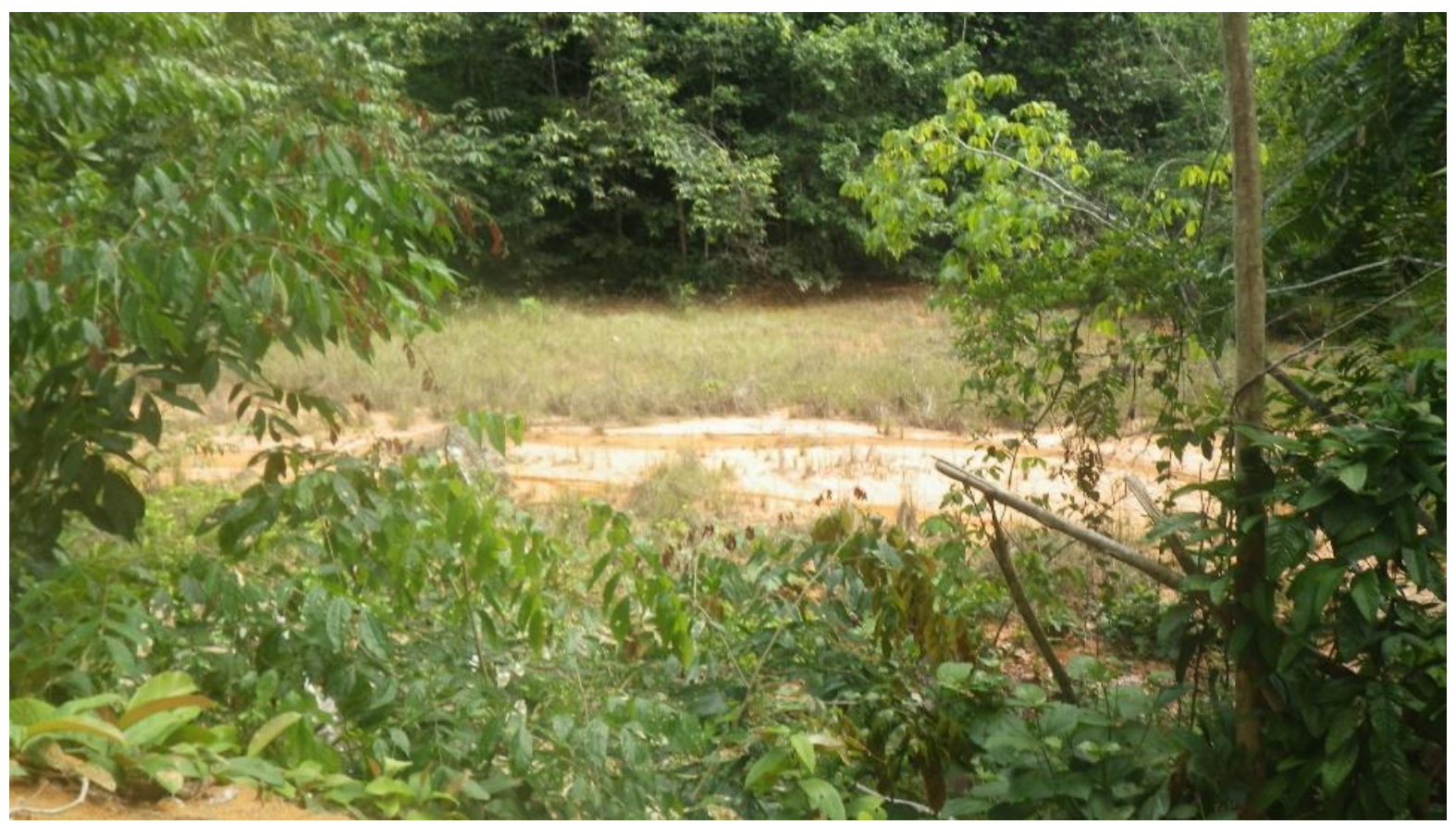

Figura 8 - Rejeito disperso e assoreado ao longo dos cursos d'água.

Em função dos vários riscos aos quais o empreendimento estava exposto, a equipe do NAP.Mineração/USP sugeriu aos empreendedores não operar na situação atual. A recomendação é a de elaborar e implementar um projeto que inclua um plano estratégico de negócio, procedimentos para regularização da área, pesquisa mineral e caracterização do depósito, e otimização dos processos de beneficiamento mineral.

Foi recomendado, de acordo com o conceito de reserva mínima, um investimento inicial de pesquisa para medir e caracterizar o depósito de rejeito. A viabilização da produção de ouro de rejeito possibilitaria produção econômica e solução do principal passivo ambiental da área. A pesquisa do minério primário e secundário podem ficar a para uma etapa seguinte, com parte dos lucros provenientes da recuperação de ouro do rejeito.

\subsubsection{Aplicação da Matriz CEBIm}

O conhecimento geológico existente na área do garimpo é apenas o mínimo para justificar o interesse do titular na manutenção dos direitos minerários. Há mapas de geologia regional e informações orais sobre as operações de garimpo conduzidas entre 2001 e 2002. Existe um relatório de campanha de sondagem cujos dados não foram adequadamente preservados, não podendo, portanto, ser 
auditado. Durante a visita da equipe do NAP, foram coletadas amostras de rejeito em que a ocorrência de ouro é comprovada. As informações geológicas confiáveis são relativamente poucas e o nível de implementação para quaisquer das atividades selecionadas na Matriz CEBIm é 1, portanto pouco relevantes. O índice CEBIm para esta área de garimpo é 2.0, o mínimo índice possível, conforme a Matriz CEBIm ilustrada na figura 9.

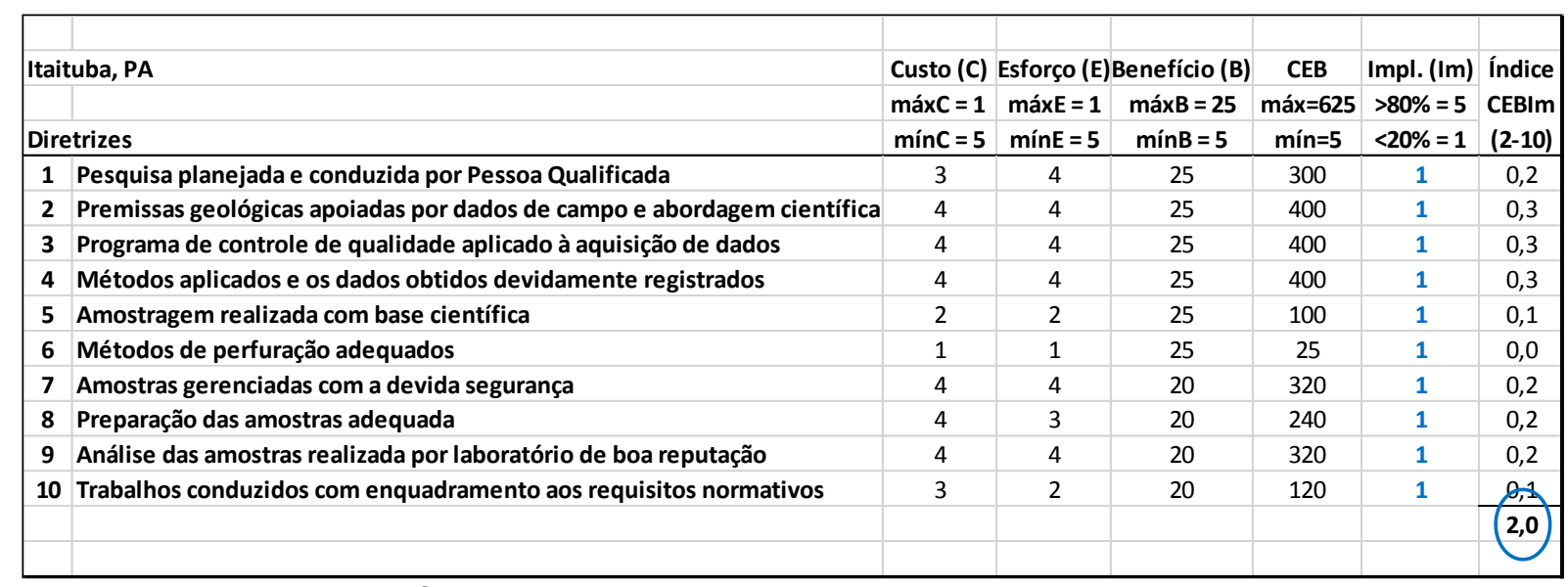

Figura 9 - Matriz CEBIm para pesquisa mineral em garimpo de ouro em Itaituba, PA.

\subsection{AplicaçÂo II: Pesquisa de Jazida de Manganês em CAetité, BA}

A pesquisa foi orientada para produção mínima e para elaboração do Relatório Final de Pesquisa (Batista, 2011), documento que deve ser elaborado e protocolado junto ao Departamento Nacional de Produção Mineral (DNPM) até a data de vencimento do Alvará de Pesquisa. O objetivo da pesquisa, portanto, foi o de demonstrar ao DNPM que há uma reserva mínima suficiente para garantir a viabilidade do projeto.

A análise quantitativa e qualitativa do depósito foi elaborada através da utilização dos dados obtidos em campo e de método direto e convencional revisto e sintetizado por Popoff (1966). Os blocos de cubagem são delimitados por duas seções adjacentes de amostragem e por superfície lateral, como ilustrado na figura 10, para determinação do recurso medido do depósito. O recurso indicado é determinado nas extremidades do depósito, estendendo-se as características das seções-limites até a meia distância, bem como nos limites das seções até as meias distâncias entre furos positivos e negativos. 


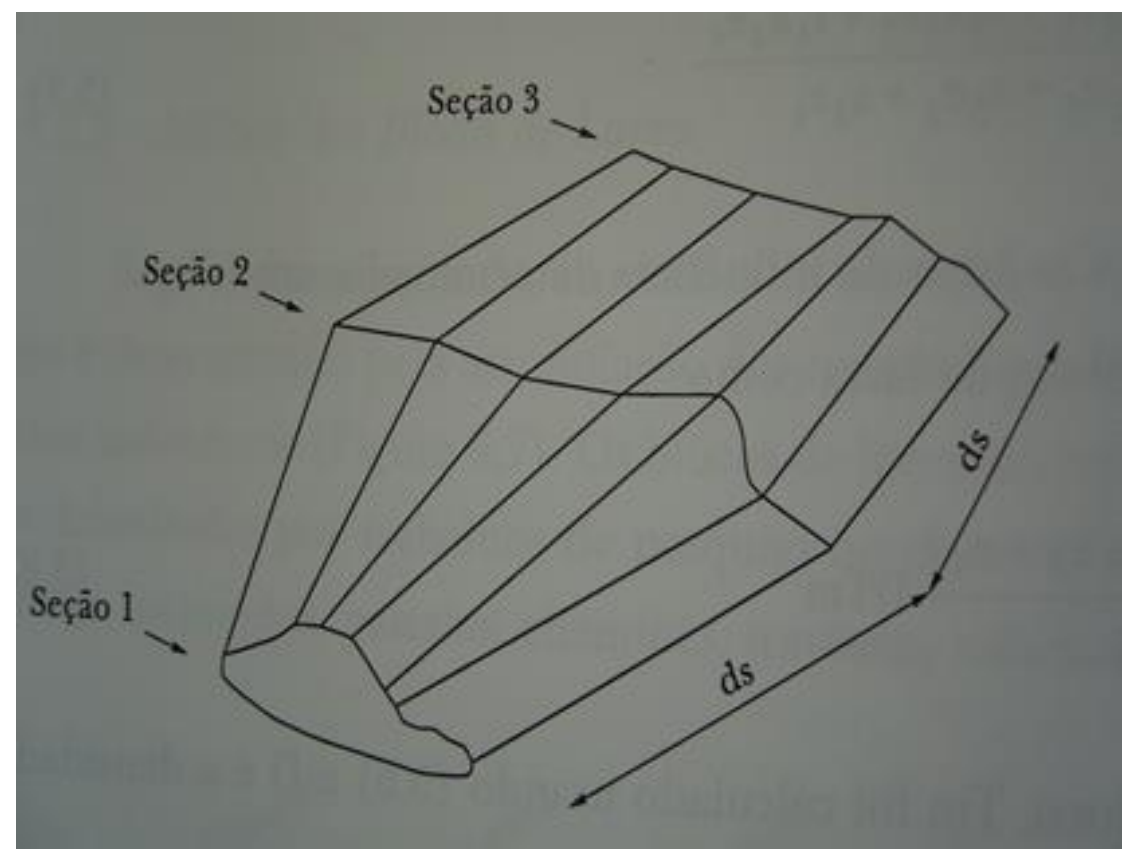

Figura 10 - Subdivisão em blocos pelo Método dos Perfis Padrão (Popoff,1966).

O procedimento para cálculo de recursos ocorreu como segue:

a) Delimitar a área de interesse, discriminando os furos positivos dos negativos, pela aplicação de critérios técnicos e econômicos (espessura mínima, teor de corte, recuperação etc.). Para o estudo em questão, foram analisados poços;

b) Calcular a área das seções. A figura 11 ilustra a seção de amostragem com furos de sonda separados por uma distância constate. Nesse trabalho, a distância entre os poços não foi constante;

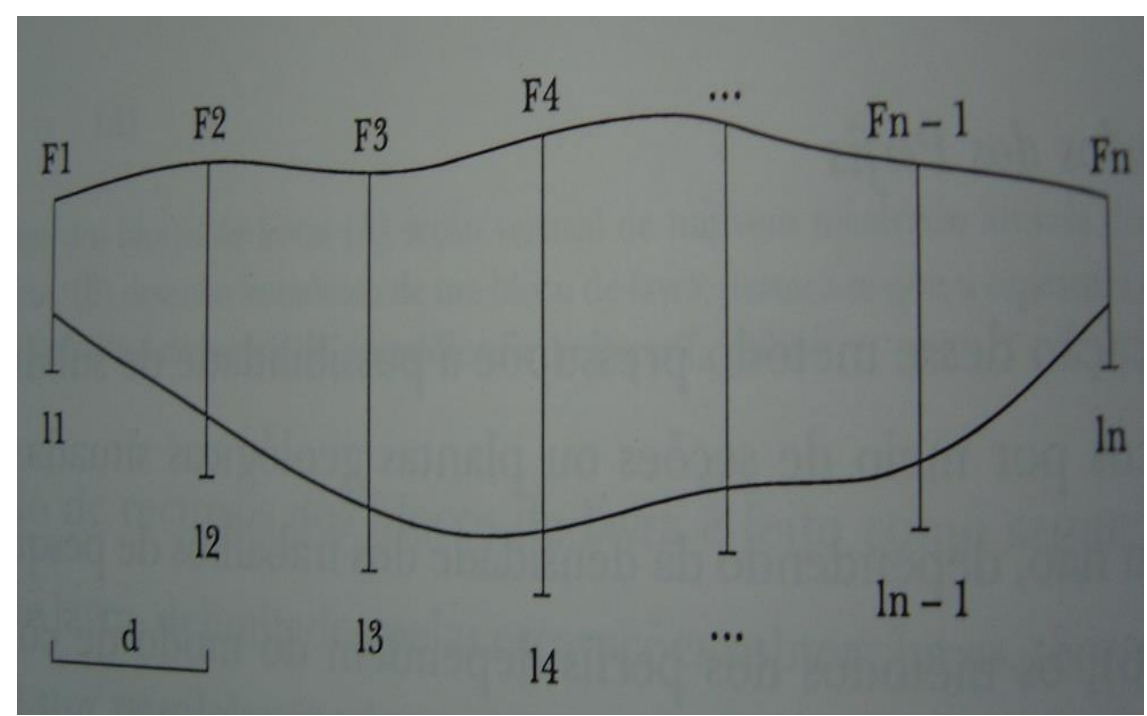

Figura 11 - Seção de amostragem com furos de sonda e distância constante (Popoff,1966). 
c) Calcular o teor médio de cada furo na seção de amostragem. Nesse caso foi utilizado o teor do material coluvionar e eluvionar retirado de cada poço;

d) Determinar o teor médio da seção;

e) Computar o teor médio do bloco de cubagem entre duas seções adjacentes de amostragem;

f) Definir o volume do bloco de cubagem. A equação da área média para cálculo de volumes é precisa quando as áreas são aproximadamente iguais, porém quando estas forem diferentes a equação do tronco de cone proporciona resultados mais exatos;

g) Avaliar os recursos dos blocos;

h) Obter os recursos do depósito através da soma dos recursos dos blocos;

i) Obter o teor médio do depósito com a média dos teores médios dos blocos, ponderados pelos respectivos volumes.

\subsubsection{Levantamento Topográfico}

Inicialmente, foi realizado um levantamento com bússola declinada e carta da região, para estabelecer os limites aproximados da área. Em seguida, foi realizada uma varredura da área, com a finalidade de identificar o ponto de amarração, rios, lagos, elevações, estradas, e afloramentos de rocha manganesífera. Foram catalogados os afloramentos de rocha que justificavam, de acordo com os teores aproximados, análises mais aprofundadas.

Em sequência, foi definida a demarcação da poligonal delimitadora da área através de um equipamento GPS, marca TRIMBLE, modelo XRS-PRO, com precisão de métrica, que proporciona posições para caracterização de ponto, linha e área, coletados através do software Asset Surveyor. Foi localizado no campo o ponto de amarração, com as coordenadas fornecidas pelo DNPM, e a partir daí foram localizados os vértices da área de pesquisa. Estes pontos coletados geram um arquivo que é corrigido em tempo real, pelo sistema RACAL e pós - processados (refinados) em escritório através do software de correção diferencial Pathfinder Office 2.51, com o uso de arquivos fornecidos via internet pela base de Feira de Santana, BA. 


\subsubsection{Levantamento Geológico}

As ocorrências de manganês do distrito de Licínio Almeida, Bahia, estão distribuídas ao longo de uma sequência de rochas metafóricas proterozóicas, de aproximadamente 75 km de extensão por 20 km de largura, dispostas segundo uma direção norte-sul, entre os municípios de Licínio de Almeida e Caetité. Os blocos e fragmentos evidenciam pouco transporte em relação à rocha-fonte, mas há situações em que estratificações cruzadas indicam um transporte subaquoso de alta energia, devido a enxurradas sazonais.

Durante o reconhecimento de campo da área e da geologia local, foi observada em afloramentos e cavas a ocorrência de minério de manganês de teores ao redor de 40\% em uma área de cerca de $35 \mathrm{Ha}$. Foram identificados na área pesquisada dois tipos de minérios característicos da formação Licínio de Almeida, o minério tipo primário, de embasamento, lenticular, na porção leste do alvo (Figura 12), e o minério tipo secundário, localizado na faixa centro-oeste do alvo (Figura 13).

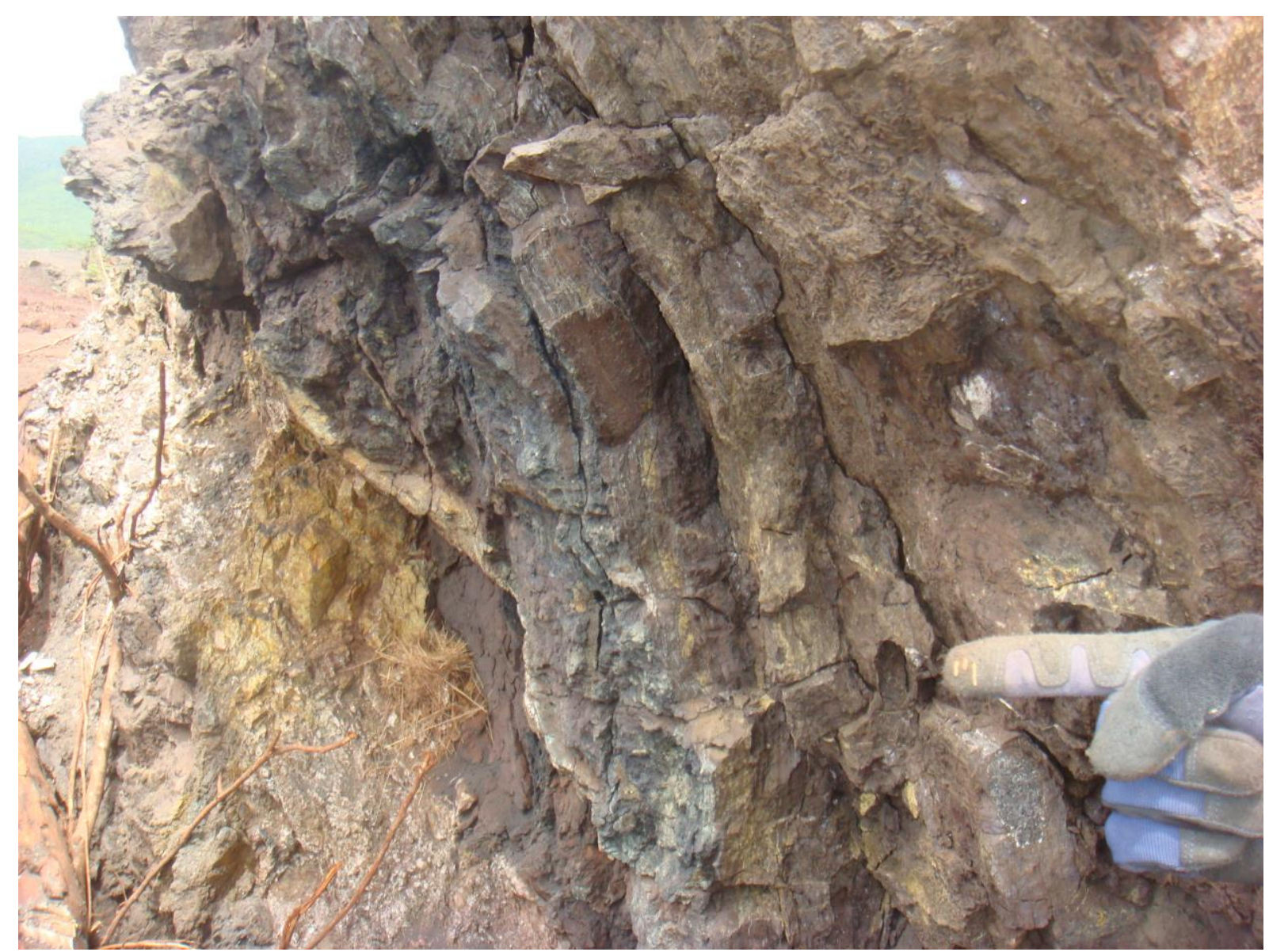

Figura 12 - Encaixe do minério tipo embasamento. 


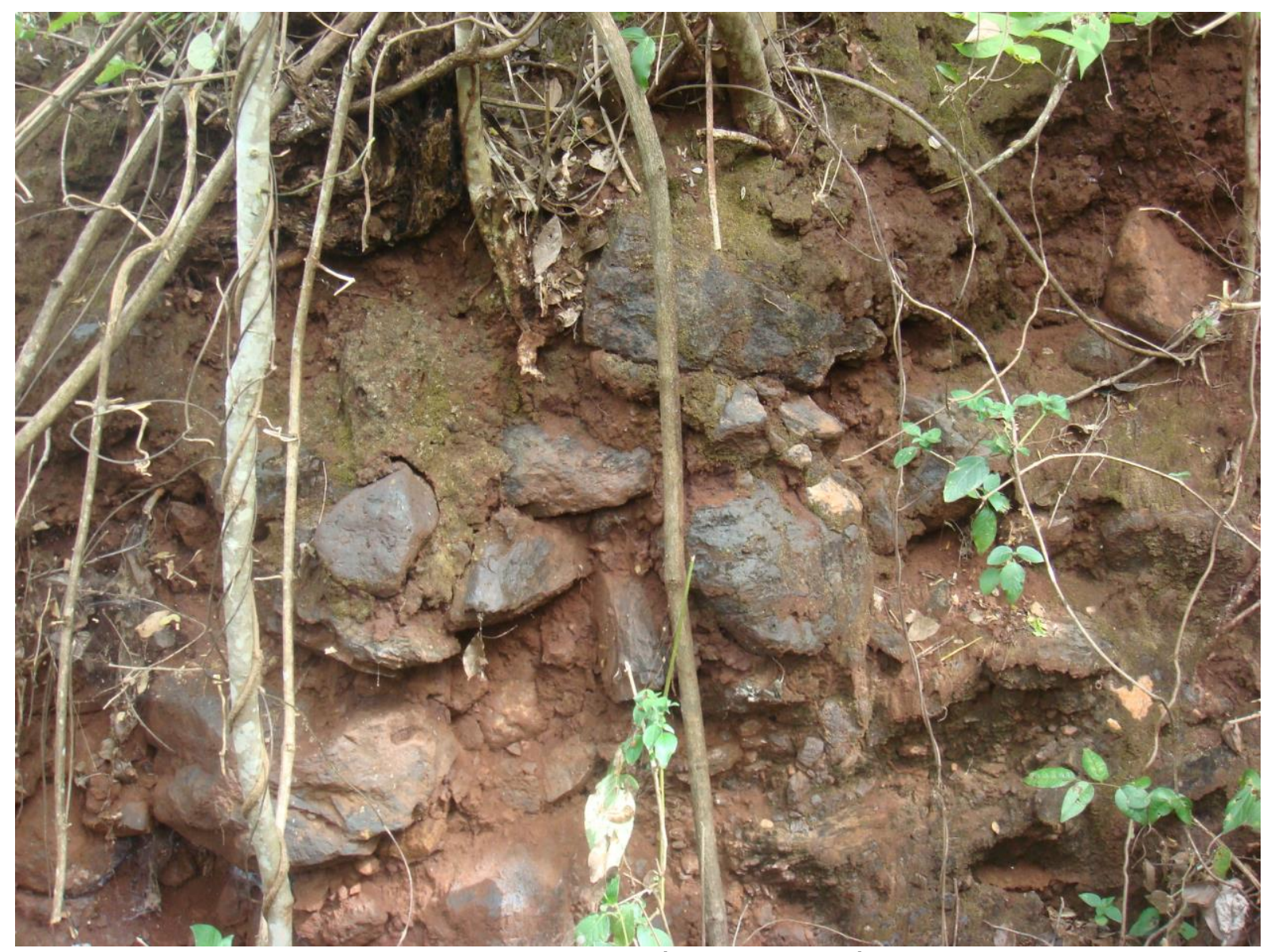

Figura 13 - Minério tipo secundário.

O minério lenticular possui características diferentes nos diversos locais onde aflora, sendo ora compacto, bandado ou não, e ora pulverulento. As lentes posicionam-se segundo $\mathrm{N} 35^{\circ}-55^{\circ} \mathrm{W}$, mergulhando 25 a $75^{\circ}$ tanto para sudoeste quanto para nordeste, estando dobradas concordantemente com a rocha encaixante. A intensa oxidação a que foram submetidos esses depósitos secundários acarretou enriquecimento supergênico, originando teor superior ao do minério primário.

O potencial econômico dos depósitos secundários deriva da grande concentração de blocos e fragmentos não consolidados de manganês, da facilidade na extração e dos teores frequentemente acima de $40 \%$. Por esse motivo o objetivo da pesquisa foi o de cubar o depósito de minério secundário.

As dimensões desses depósitos são bastante variáveis. A sua irregularidade e a repetição de pacotes de minério rolado, separados por horizontes de solo, sugerem mais de um ciclo de deposição. O minério secundário não ocorre apenas na forma de rolados. Camadas primárias são oxidadas e, com a alteração nas relações 
mineralógicas, aumenta a concentração de óxidos de manganês, enquanto ferro e sílica são lixiviados. Matacões de minério manganesífero in situ ocupam horizontes de topo e base bem definidos, no mesmo espaço que era ocupado pela rocha primária.

Uma característica do minério do depósito avaliado é seu magnetismo, devido à presença de jacobsita, cuja relação com os óxidos secundários de manganês comanda a variação nos teores de $\mathrm{Mn}$, Fe e $\mathrm{SiO}_{2}$. Em geral, os teores de $\mathrm{Mn}$ variam entre 39 e 45\%, de Fe, entre 10 e 16\% e $\mathrm{SiO}_{2}$, entre 0,4 e 14\%. Os principais minerais de manganês identificados são bixbyíta, jacobsita, haussmannita, manganita, criptomelana, todorokita e pirolusita.

\subsubsection{Abertura de Poços e Trincheiras}

Foi programada a abertura de poços de 3 metros e trincheiras de 3 a 5 metros de profundidade (Figuras 14 a 18) em área de 35 ha ao redor da cava.

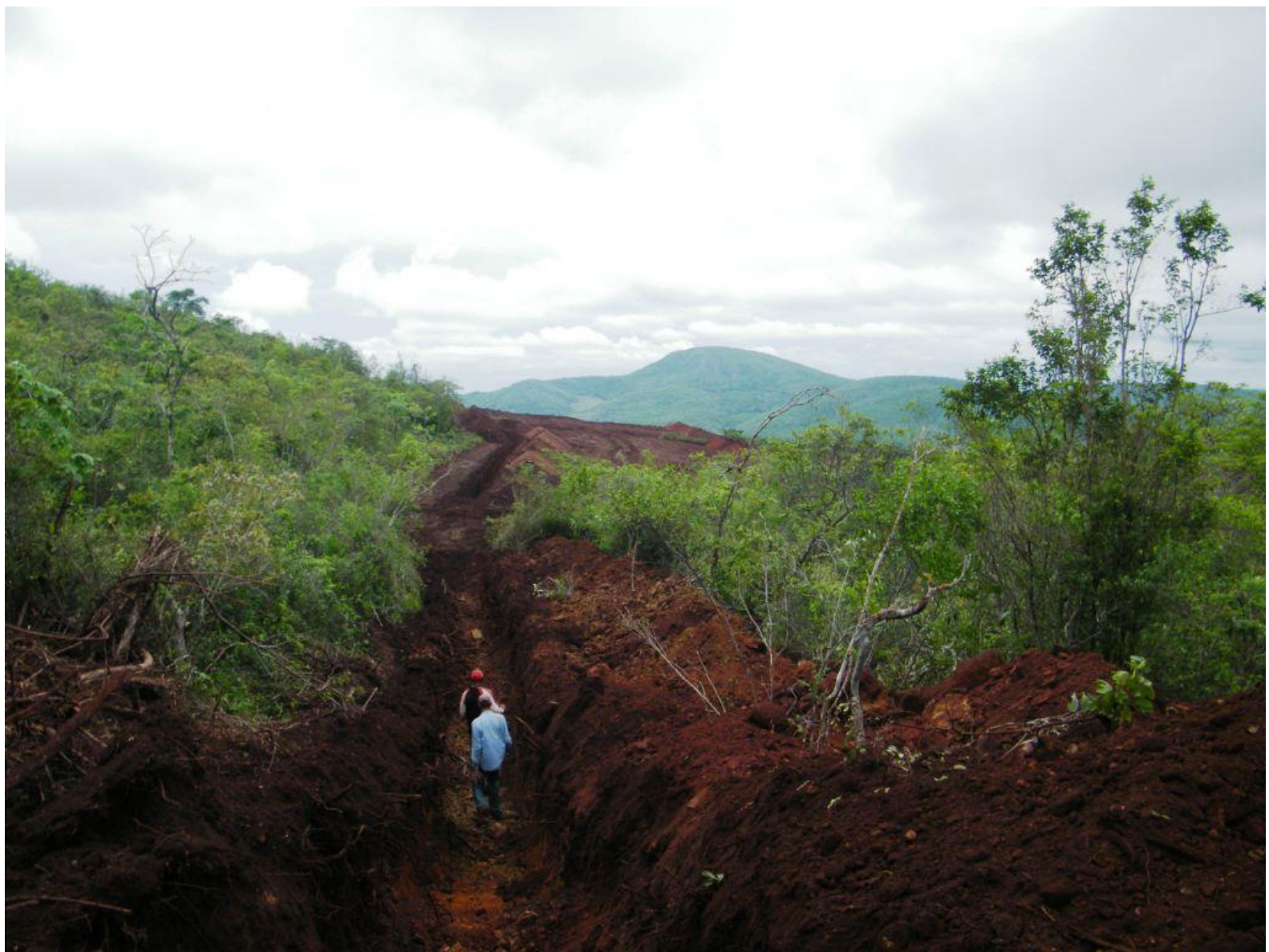

Figura 14 - Trincheira. 


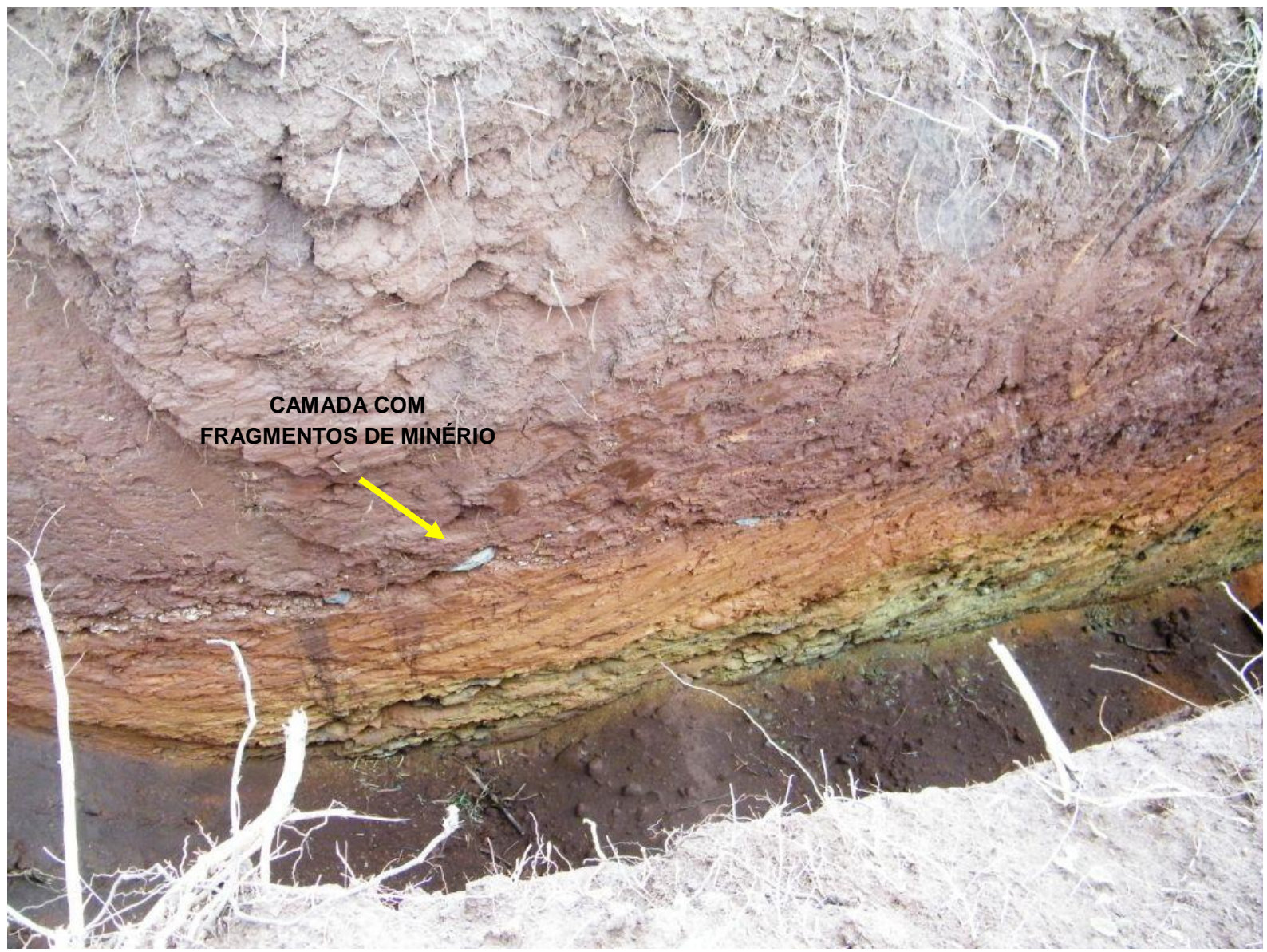

Figura 15 - Detalhe das camadas litológicas até $4 \mathrm{~m}$ de profundidade em trincheira.

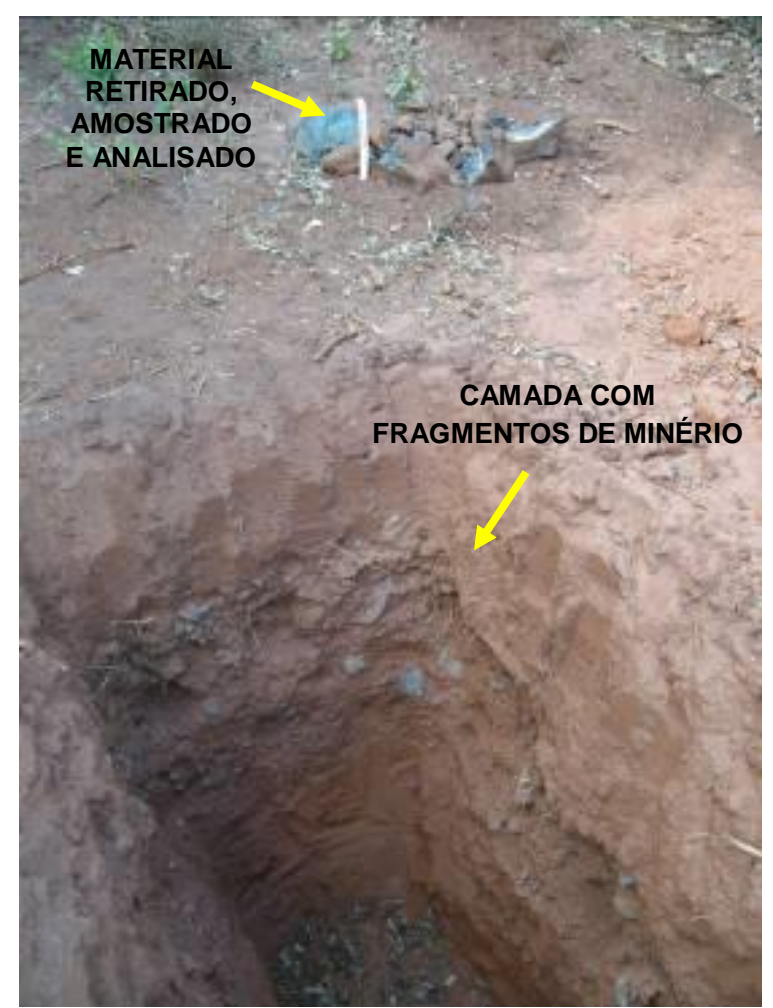

Figura 16 - Minério tipo secundário no poço 27.

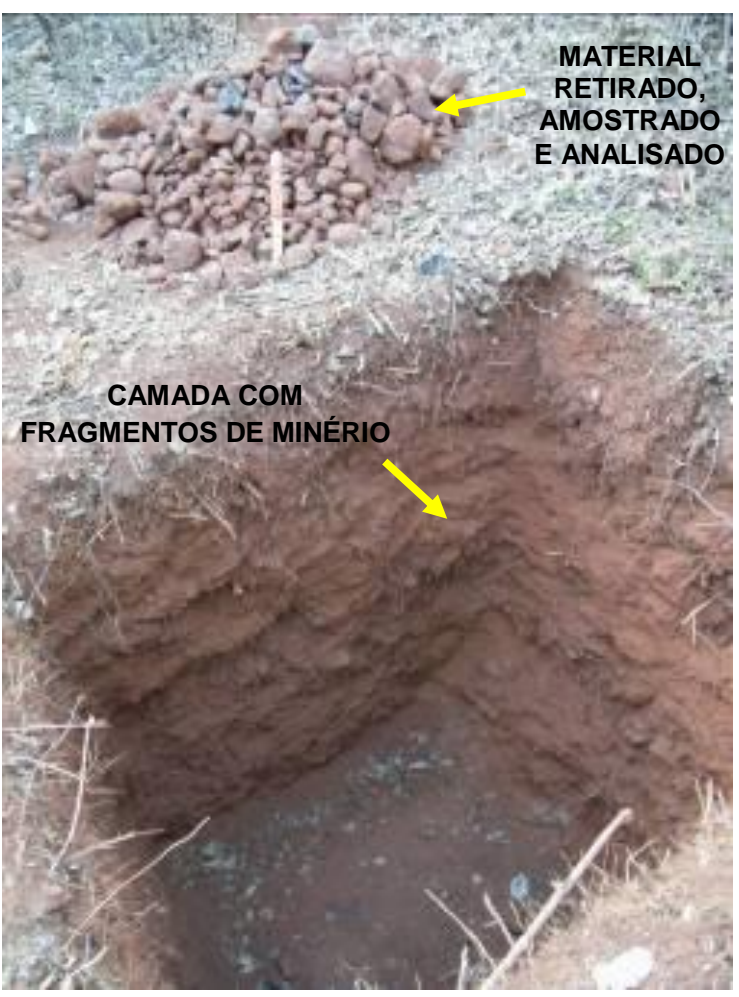

Figura 17 - Minério tipo secundário no poço 32. 


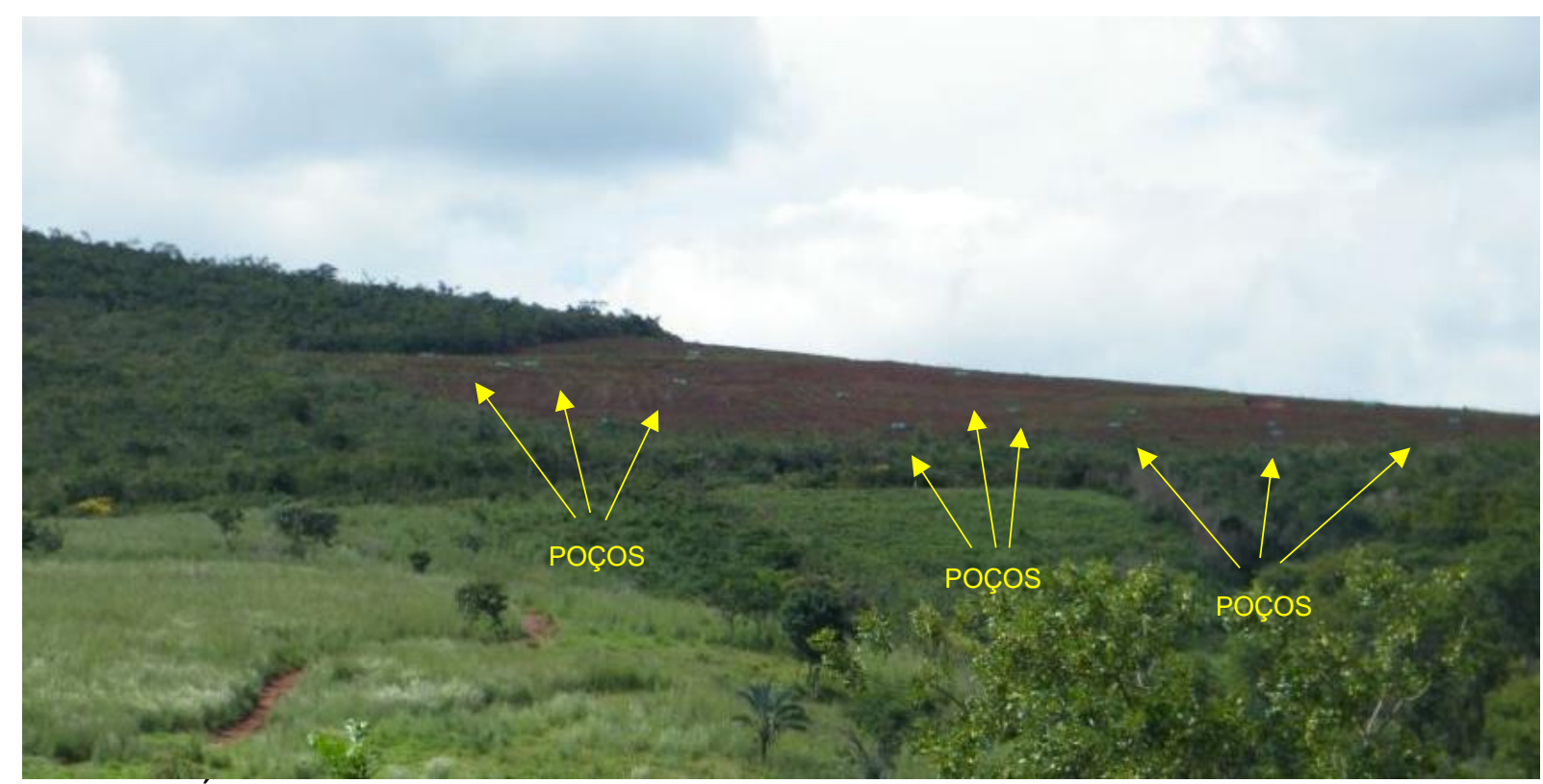

Figura 18 - Área desmatada em que foram abertos os poços e as trincheiras. Os pequenos pontos em azul destacados são os poços protegidos por tela.

\subsubsection{Amostragem e Análise}

Foram coletadas amostras representativas de cada um dos poços e das trincheiras. As amostras foram preparadas na área do empreendimento e encaminhadas para análise no Laboratório de Caracterização Tecnológica do Departamento de Engenharia de Minas e Petróleo da Escola Politécnica da Universidade de São Paulo - USP. As análises foram realizadas através do método de análise quantitativa em amostra fundida com tetraborato de lítio anidro, por comparação com materiais certificados de referência na calibração Min Mn TBL, em espectrômetro por fluorescência de raios X Axios Advanced, marca PANalytical. Perda ao fogo (PF) efetuado a $1.050^{\circ} \mathrm{C}$ por $1 \mathrm{~h}$. O método de análise adotado proporciona uma relação custo-benefício interessante e boa precisão na análise de amostras de minério de manganês, sendo possível comparar os resultados de manganês, ferro, sílica, fósforo e alumina.

Após analises estatísticas, a $\mathrm{m}$ do depósito pesquisado foram determinados como segue: $\mathrm{Mn}: 43,86 \%$; $\mathrm{Fe}: 12,45 \%$; $\mathrm{SiO}_{2}$ : 3,49\%; e $\mathrm{Al}_{2} \mathrm{O}_{3}: 2,70 \%$.

A Relação Fe/Mn é 3,52, normal para o ambiente geológico e características do minério da região de Licínio de Almeida. 


\subsubsection{Cubagem}

O levantamento de campo identificou três corpos com alto teor de manganês de destacados na área avaliada, os alvos leste, oeste e norte. A cubagem da jazida foi realizada em função das metas estabelecidas para o alvo leste, que apresentou melhores condições para rápido retorno das atividades de processamento mineral.

Para determinação do volume do alvo leste, foram coletados, através de GPS, os pontos dos poços e das trincheiras. Esses pontos foram exportados para o software TOPOGRAPH versão 2.44, e foi traçada uma malha triangular entre eles, de onde foram geradas as curvas de níveis com intervalo de 1 metro. Em seguida, foi traçado um eixo que define um perfil longitudinal. Ao longo do eixo foram geradas seções transversais com intervalo de 30 m, e determinadas as áreas e volumes das seções.

O volume do depósito de minério secundário foi obtido através da soma dos volumes dos vários blocos em que a camada mineralizada foi dividida, conforme mostrado nas tabelas 3 e 4 a seguir. A densidade de minério foi estimada em 5,1 t/m³.

Tabela 3 - Recurso medido do depósito de manganês em Caetité (Batista, 2011).

\begin{tabular}{|c|c|c|c|}
\hline \multicolumn{4}{|c|}{ Recurso Medido } \\
\hline Seções & Área das Seções $\left(\mathbf{m}^{\mathbf{2}}\right)$ & Valor $\left(\mathbf{m}^{\mathbf{3}}\right)$ & Valor $\mathbf{( t )}$ \\
\hline 14 & 0,00 & - & - \\
\hline 13 & 10,00 & 100,00 & 510,00 \\
\hline 12 & 182,77 & $2.355,22$ & $12.011,60$ \\
\hline 11 & 32,14 & $2.915,54$ & $14.869,23$ \\
\hline 10 & 148,76 & $2.500,46$ & $12.752,34$ \\
\hline 9 & 108,23 & $3.838,77$ & $19.577,72$ \\
\hline 8 & 111,77 & $3.299,86$ & $16.829,27$ \\
\hline 7 & 184,04 & $4.392,33$ & $22.400,88$ \\
\hline 6 & 111,98 & $4.395,78$ & $22.418,46$ \\
\hline 5 & 113,30 & $3.379,18$ & $17.233,82$ \\
\hline 4 & 34,87 & $2.110,25$ & $10.762,28$ \\
\hline 3 & 123,27 & $2.237,02$ & $11.408,82$ \\
\hline 2 & 3,81 & $1.487,52$ & $7.586,33$ \\
\hline 1 & 10,00 & 199,83 & $1.019,11$ \\
\hline 0 & 100,89 & $1.426,53$ & $7.275,31$ \\
\hline $00-30$ & 92,96 & $2.906,94$ & $14.825,39$ \\
\hline $00-60$ & 248,78 & $4.938,14$ & $25.184,53$ \\
\hline $00-90$ & 0,00 & $2.487,80$ & $12.687,78$ \\
\hline & Volume total & $44.971,15$ & $229.352,88$ \\
\hline
\end{tabular}


Tabela 4 - Recurso inferido do depósito de manganês em Caetité (Batista, 2011).

\begin{tabular}{|c|c|c|c|}
\hline \multicolumn{4}{|c|}{ Recurso Inferido } \\
\hline Seções & Área das Seções $\left(\mathrm{m}^{2}\right)$ & Valor $\left(m^{3}\right)$ & Valor $(t)$ \\
\hline 14 & 0,00 & - & - \\
\hline 13 & 0,00 & - & - \\
\hline 12 & 11,01 & 110,10 & 561,51 \\
\hline 11 & 137,60 & $1.875,33$ & $9.564,17$ \\
\hline 10 & 50,15 & $2.708,20$ & $13.811,82$ \\
\hline 9 & 35,80 & $1.283,22$ & $6.544,41$ \\
\hline 8 & 61,75 & $1.445,68$ & $7.372,95$ \\
\hline 7 & 41,47 & $1.538,24$ & $7.845,03$ \\
\hline 6 & 113,40 & $2.234,46$ & $11.395,76$ \\
\hline 5 & 1,84 & $1.296,85$ & $6.613,93$ \\
\hline 4 & 85,24 & 996,04 & $5.079,79$ \\
\hline 3 & 1,53 & 981,90 & $5.007,69$ \\
\hline 2 & 146,56 & $1.630,65$ & $8.316,29$ \\
\hline 1 & 126,45 & $4.091,44$ & $20.866,35$ \\
\hline 0 & 145,69 & $4.078,70$ & $20.801,35$ \\
\hline $00-30$ & 71,36 & $3.190,13$ & $16.269,66$ \\
\hline $00-60$ & 1,10 & 813,20 & $4.147,31$ \\
\hline $00-90$ & 75,39 & 855,97 & $4.365,42$ \\
\hline & olume total & $29.130,09$ & $148.563,43$ \\
\hline
\end{tabular}

A soma dos recursos medido (229.352,88 t) e inferido (148.563,43 t) definiu a cubagem em 377.916,31 t.

\subsubsection{Aplicação da Matriz CEBIm}

A pesquisa realizada atingiu o objetivo de demonstrar viabilidade econômica no Relatório Final de Pesquisa protocolado junto ao DNPM. Foi demonstrada e existência de uma camada de minério de manganês secundário de alto teor e de fácil extração, pois é fragmentado e se encontra em baixa profundidade. No entanto, o minério de embasamento não foi analisado. A avaliação se limitou a uma área de apenas 35 ha e profundidade de até $3 \mathrm{~m}$. Os métodos de prospecção adotados não parecem ter sido os mais adequados, uma vez que um 
levantamento geofísico e o uso de trado são atividades relativamente econômicas que poderiam identificar um depósito maior do que o calculado. Por fim, os poços e as trincheiras foram abertos sem rigor geoestatístico.

Como muitas atividades foram implementadas parcialmente ou sem atender rigorosamente as diretrizes de melhore práticas da matriz, os níveis de implementação de cada atividade são estimados e inseridos na Matriz CEBIm conforme apresentado na figura 19. O índice CEBIm da pesquisa realizada nesse empreendimento é 5.2 .

1. Pesquisa projetada e conduzida por Pessoa Qualificada:

2. Premissas geológicas apoiadas por dados de campo e abordagem científica:

3. Programa de controle de qualidade aplicado à aquisição de dados:

4. Métodos aplicados e os dados obtidos devidamente registrados:

5. Amostragem realizada com base científica:

6. Métodos de perfuração adequados:

7. Amostras gerenciadas com a devida segurança:

8. Preparação das amostras adequada:

9. Análise das amostras realizada por laboratório de boa reputação:

10. Trabalhos conduzidos com enquadramento aos requisitos normativos:

\begin{tabular}{|c|c|c|c|c|c|c|c|}
\hline \multicolumn{2}{|c|}{ Caetité, BA } & Custo (C) & \multicolumn{2}{|c|}{ Esforço (E)Benefício (B) } & ) CEB & \multirow{2}{*}{$\begin{array}{c}\text { Impl. (Im) } \\
>80 \%=5\end{array}$} & \multirow{2}{*}{$\begin{array}{l}\text { Índice } \\
\text { CEBIm }\end{array}$} \\
\hline & & máxC $=1$ & máxE = 1 & máxB = 25 & máx $=625$ & & \\
\hline \multicolumn{2}{|c|}{ Diretrizes } & mínC = 5 & mínE = 5 & mínB = 5 & mín=5 & $<20 \%=1$ & $(2-10)$ \\
\hline 1 & Pesquisa planejada e conduzida por Pessoa Qualificada & 3 & 4 & 25 & 300 & 1 & 0,2 \\
\hline 2 & Premissas geológicas apoiadas por dados de campo e abordagem científica & 4 & 4 & 25 & 400 & 2 & 0,6 \\
\hline 3 & Programa de controle de qualidade aplicado à aquisição de dados & 4 & 4 & 25 & 400 & 2 & 0,6 \\
\hline 4 & Métodos aplicados e os dados obtidos devidamente registrados & 4 & 4 & 25 & 400 & 2 & 0,6 \\
\hline 5 & Amostragem realizada com base científica & 2 & 2 & 25 & 100 & 2 & 0,2 \\
\hline 6 & Métodos de perfuração adequados & 1 & 1 & 25 & 25 & 2 & 0,0 \\
\hline 7 & Amostras gerenciadas com a devida segurança & 4 & 4 & 20 & 320 & 3 & 0,7 \\
\hline 8 & Preparação das amostras adequada & 4 & 3 & 20 & 240 & 3 & 0,5 \\
\hline 9 & Análise das amostras realizada por laboratório de boa reputação & 4 & 4 & 20 & 320 & 5 & 1,2 \\
\hline 10 & Trabalhos conduzidos com enquadramento aos requisitos normativos & 3 & 2 & 20 & 120 & 5 & 0,5 \\
\hline & & & & & & & 5,2 \\
\hline & & & & & & & \\
\hline
\end{tabular}

Figura 19 - Matriz CEBIm para pesquisa mineral em depósito de manganês em Caetité, BA.

\subsection{Aplicação III: Pesquisa de JaZida de Manganês em ItAPIRA, SP}

Os objetivos da pesquisa realizada foram o de elaborar um modelo preliminar do depósito de manganês e recomendar campanha de sondagem com base no 
modelo preliminar do depósito (Tichauer, 2014). Os trabalhos foram iniciados em janeiro de 2014 com o levantamento topográfico e o mapeamento da geologia estrutural do depósito e arredores. Em seguida, ensaios geofísicos foram conduzidos. A interpretação dos dados obtidos gerou o modelo geológico preliminar do depósito de manganês. O fluxograma do programa de pesquisa proposto é ilustrado na figura 20.

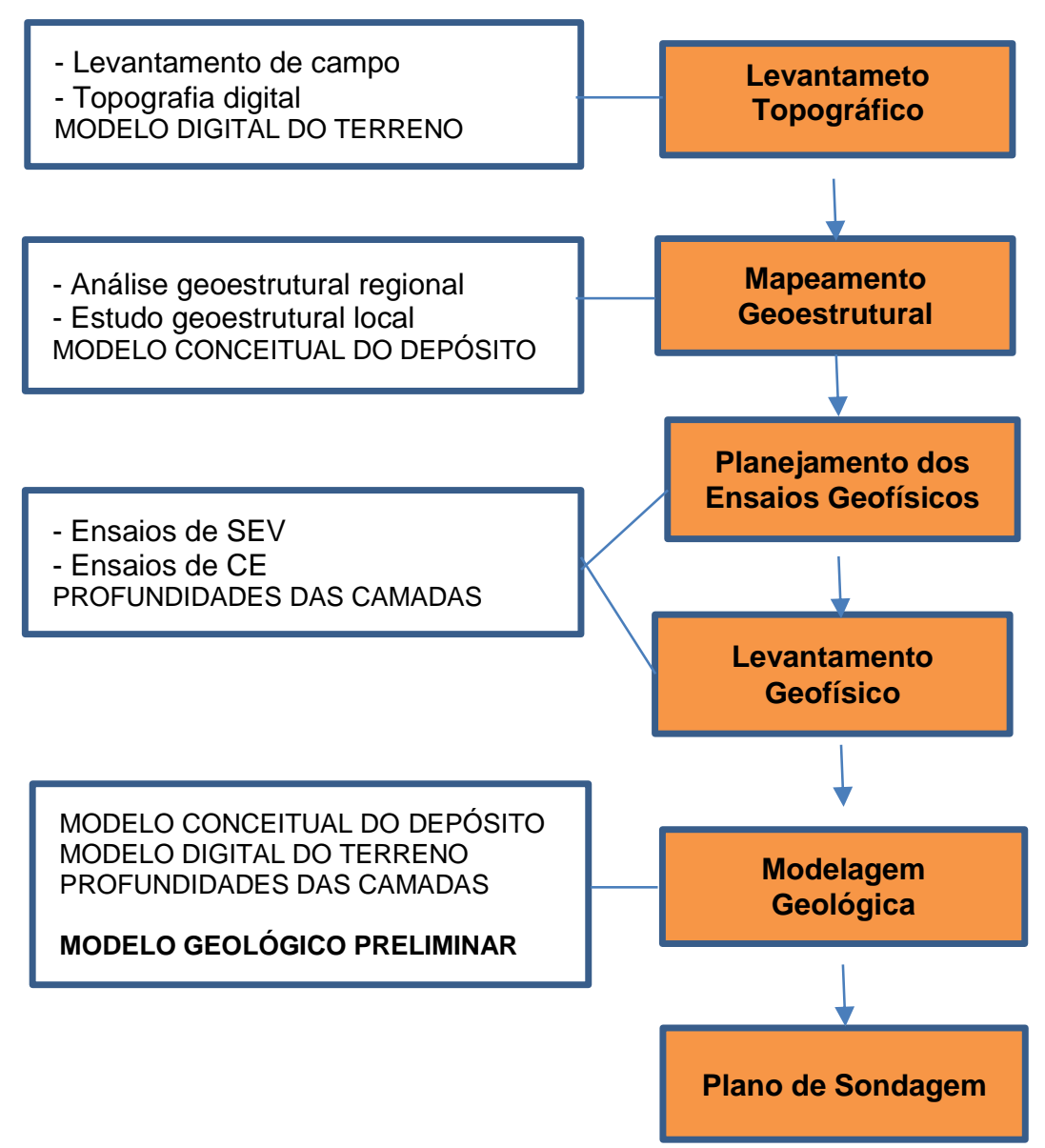

Figura 20 - Fluxograma de atividades para modelagem do depósito (NAP.Mineração/USP, 2014).

\subsubsection{Levantamento Topográfico}

As atividades de campo se iniciaram com um levantamento em terreno para detalhamento das áreas próximas aos afloramentos de minério de manganês e aos antigos trabalhos de lavra na área do depósito e proximidades. Foi utilizado um equipamento GPS portátil, calibrado para o elipsoide WGS-84, e a altitude de cada ponto mensurado foi determinada pelo barômetro do equipamento (Figura 21). 


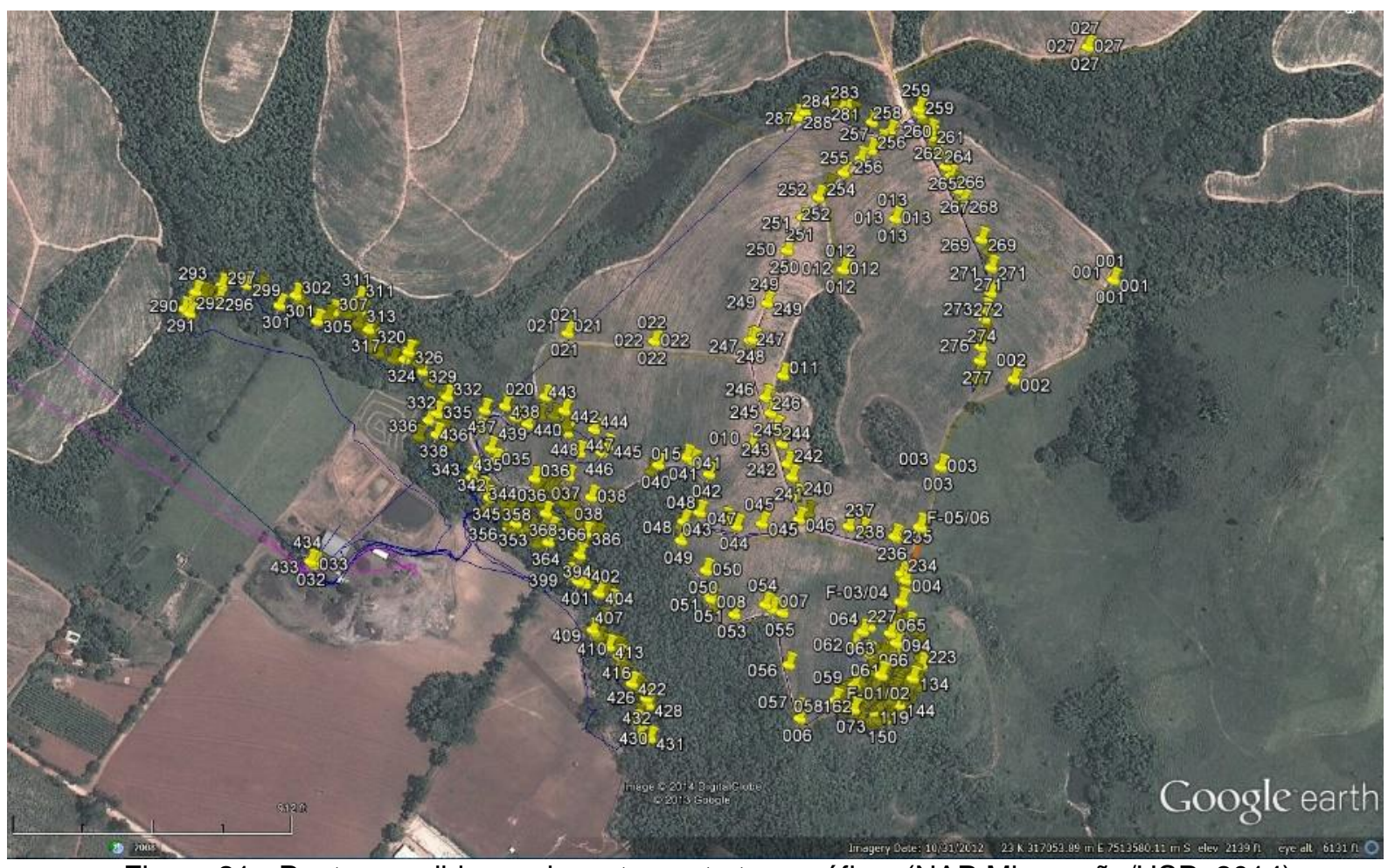

Figura 21 - Pontos medidos no levantamento topográfico. (NAP.Mineração/USP, 2014).

Posteriormente, dados topográficos complementares foram levantados a partir da carta IBGE Mogi Guaçu (Id:SF-23-Y-A-III-3) (Figura 22).

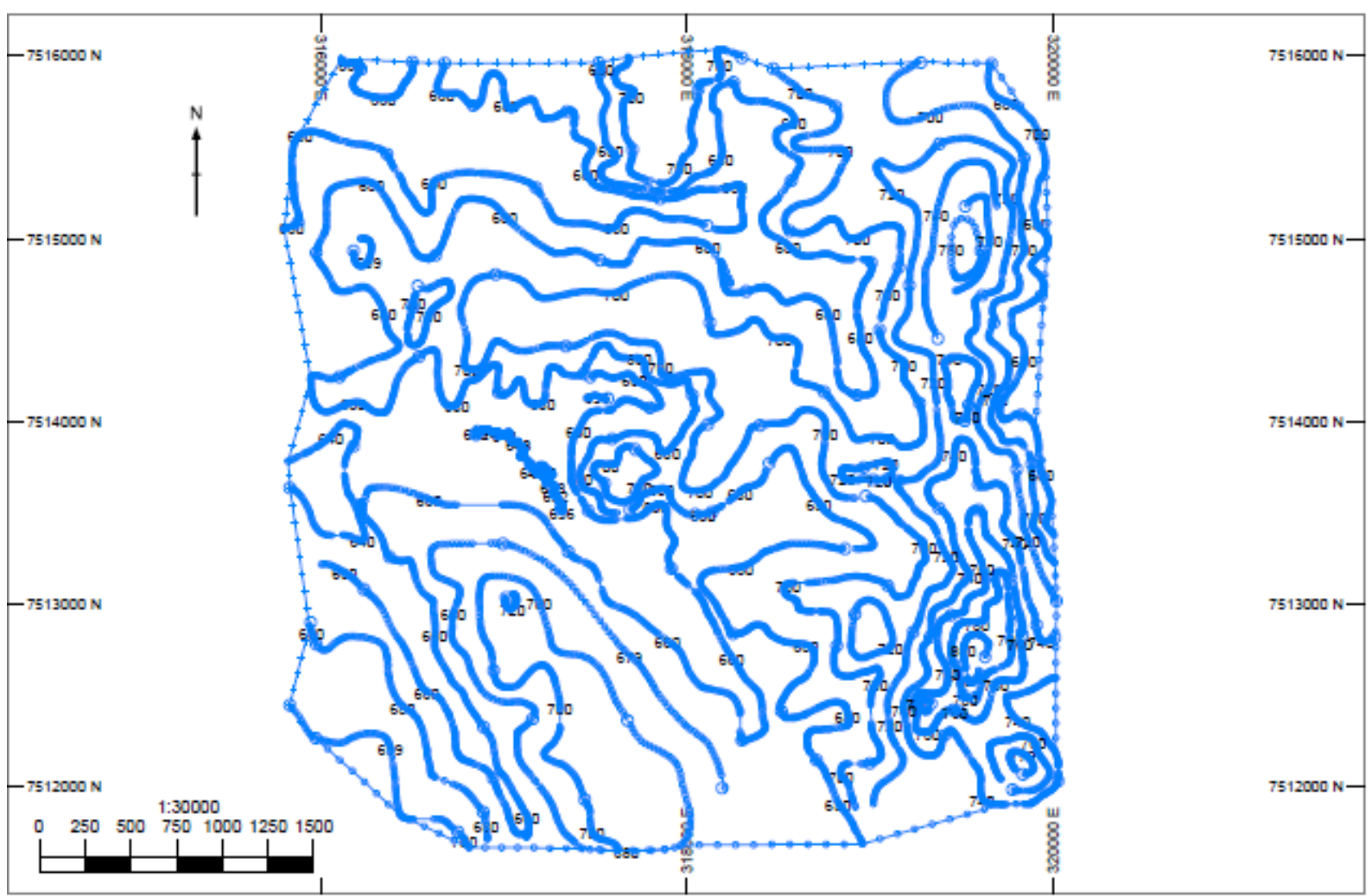

Figura 22 - Curvas de nível resultantes do levantamento topográfico. (NAP.Mineração/USP, 2014). 
Para o levantamento digital foi utilizado o sistema MICROMINE 2011 SP 5, onde as curvas de nível foram desenhadas a partir dos pontos levantados (Figura 23).

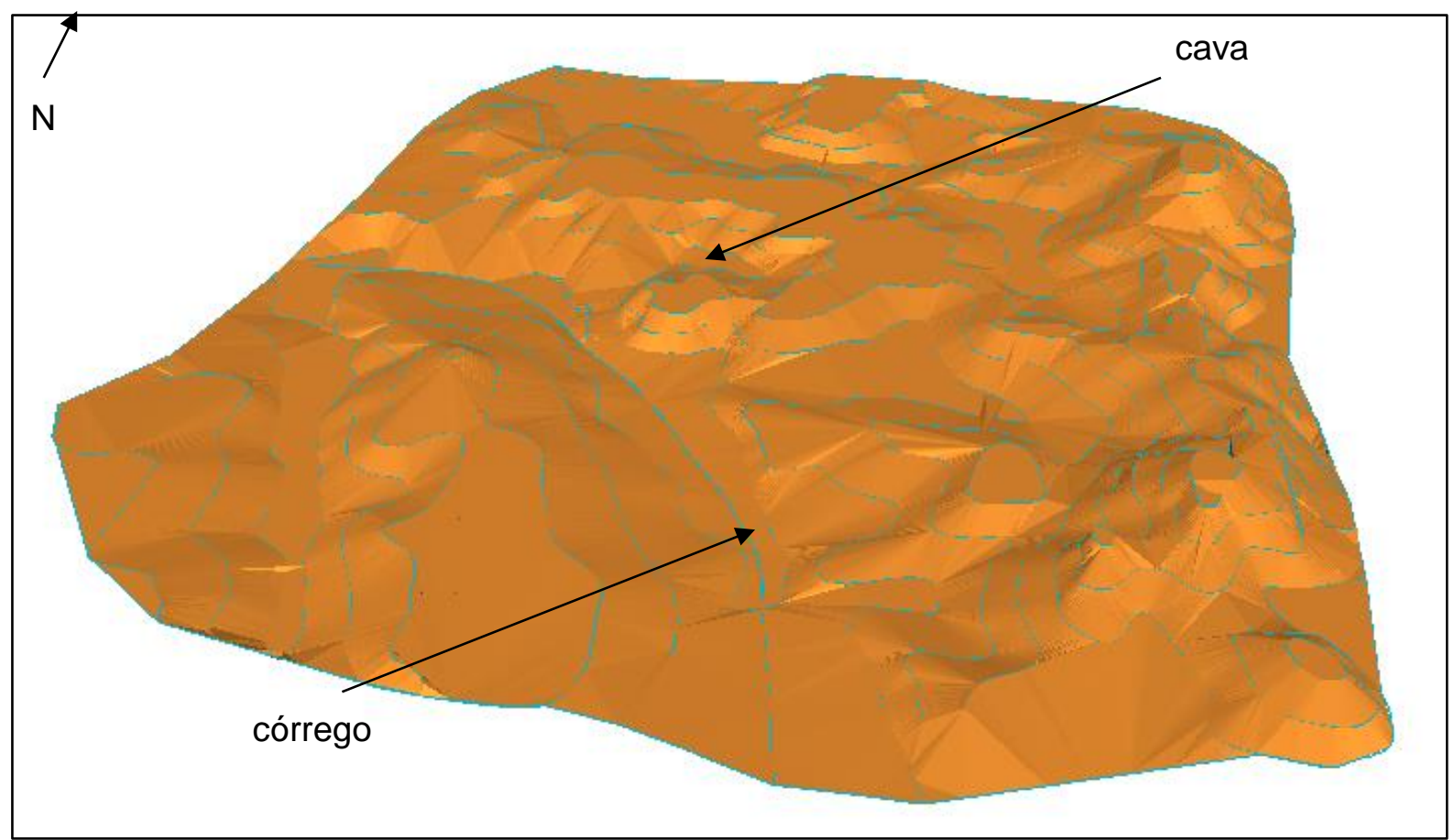

Figura 23 - Vista 3D do modelo topográfico digital. (NAP.Mineração/USP, 2014).

Observações:

- Foram observados afloramentos de minério de manganês em áreas próximas ao córrego local.

- As atitudes das camadas aflorantes de minério de manganês estão consistentemente próximas a $285^{\circ}$ de azimute com mergulho sub-vertical.

- Foram observadas zonas de cisalhamento que podem indicar a descontinuidade nas ocorrências de minério de manganês.

\subsubsection{Mapeamento Geoestrutural}

A geologia estrutural regional apresenta falhas e dobramentos com superposição tectônica das diversas litologias preexistentes, e exibe uma faixa de cisalhamento com ocorrências de corpos de manganês estirados em uma região com mais de 100 quilômetros de extensão (Figura 24). Na região de Itapira a tectônica gerou uma estrutura sinforme com eixo de direção aproximada NE-SW, com caimento suave para NE. Na aba leste essa estrutura ocorrem os corpos de 
manganês objeto deste estudo (Figura 25). Tais ocorrências acompanham a direção geral do eixo do sinclinal e são representadas por corpos extremamente deformados e boudinados suportando altos topográficos.

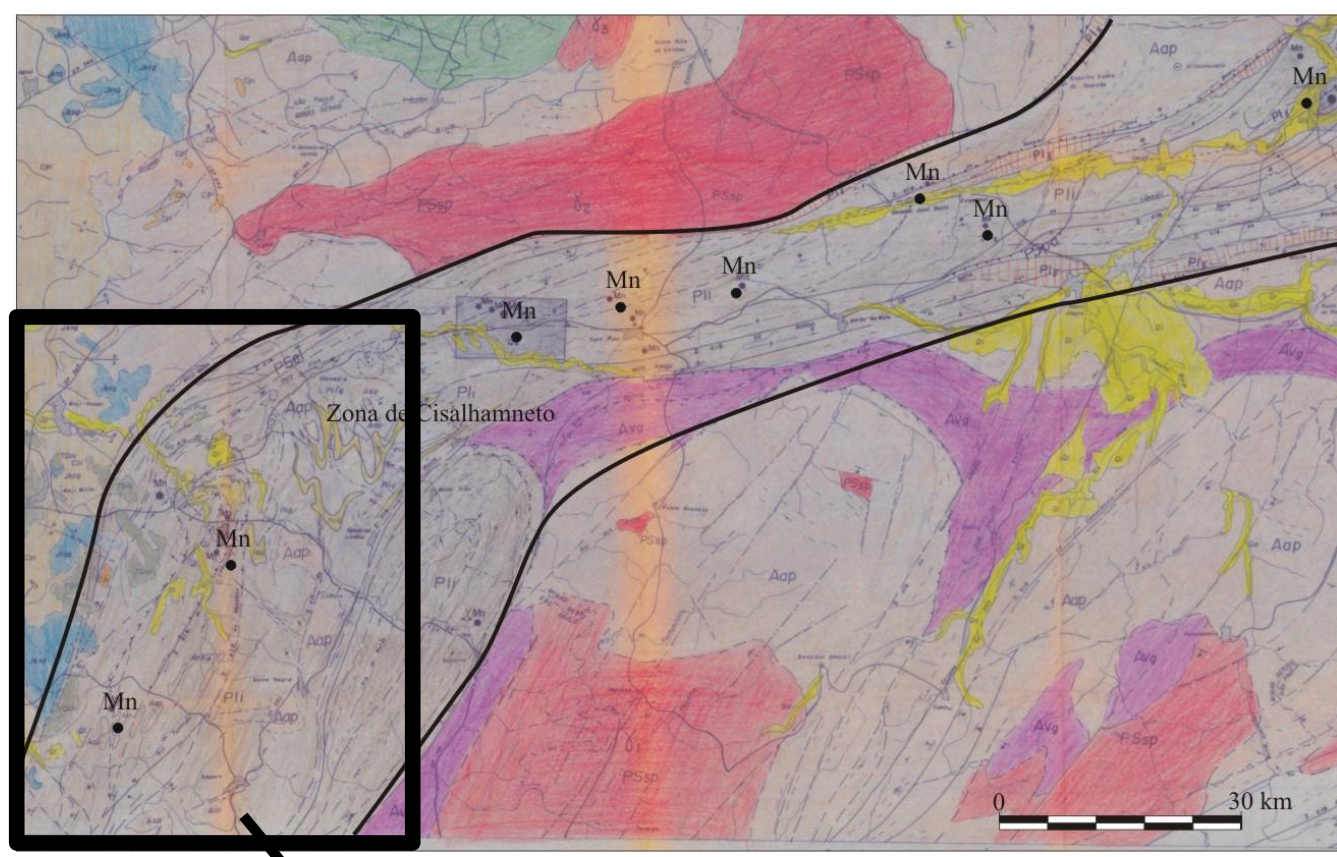

Figura 24 - Zona de cisalhamento com corpos de manganês. (NAP.Mineração/USP, 2014).

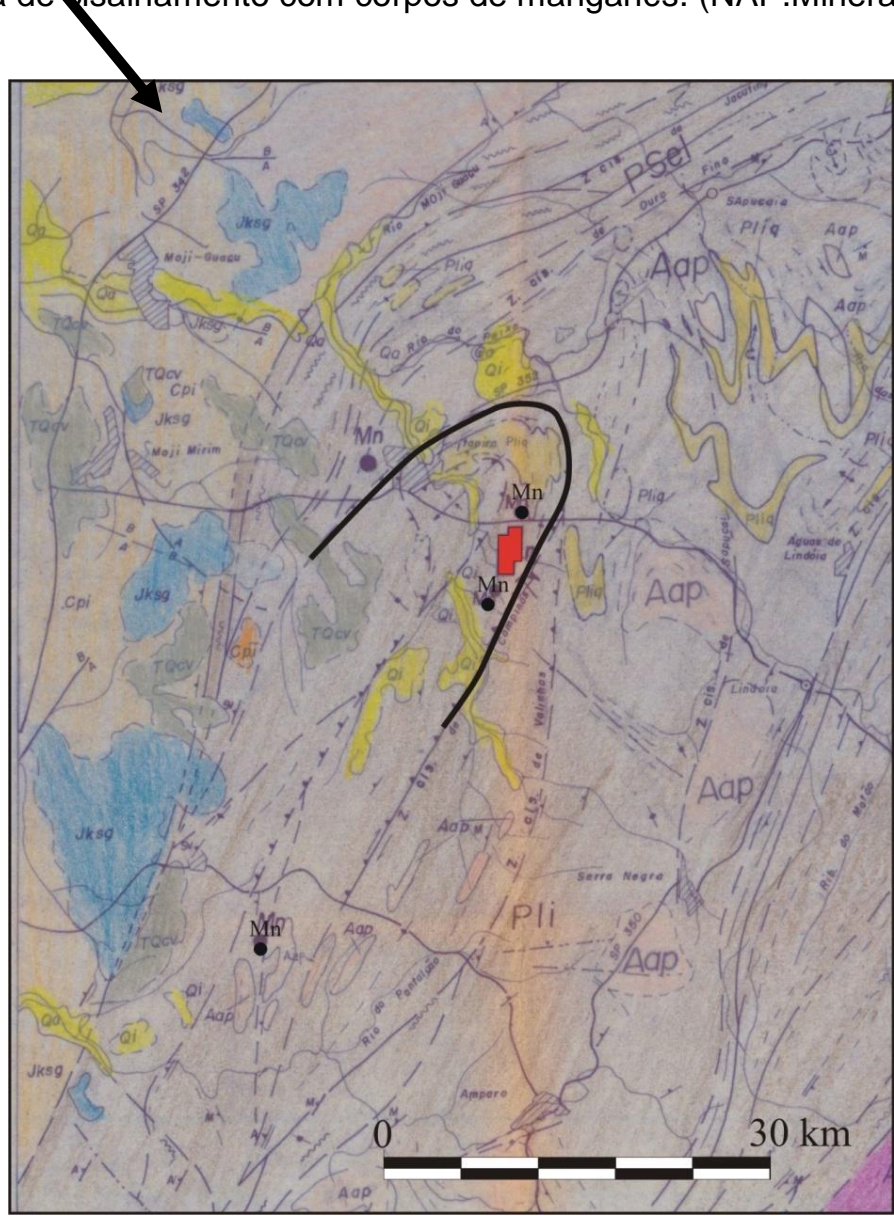

Figura 25 - Estrutura sinforme com ocorrências de corpos de manganês alinhados com o eixo. A área de concessão de lavra está destacada em vermelho. (NAP.Mineração/USP, 2014). 
A área de estudo específica deste trabalho é apresentada na figura 26. Nela foram identificados afloramentos de rochas manganesíferas com várias fases de dobramentos cujos planos axiais acompanham de uma maneira geral o trend NE-SW. As variações encontradas se referem à direção de mergulho, que mantêm um valor alto mas varia de quadrante, ora para NW ora para SE.

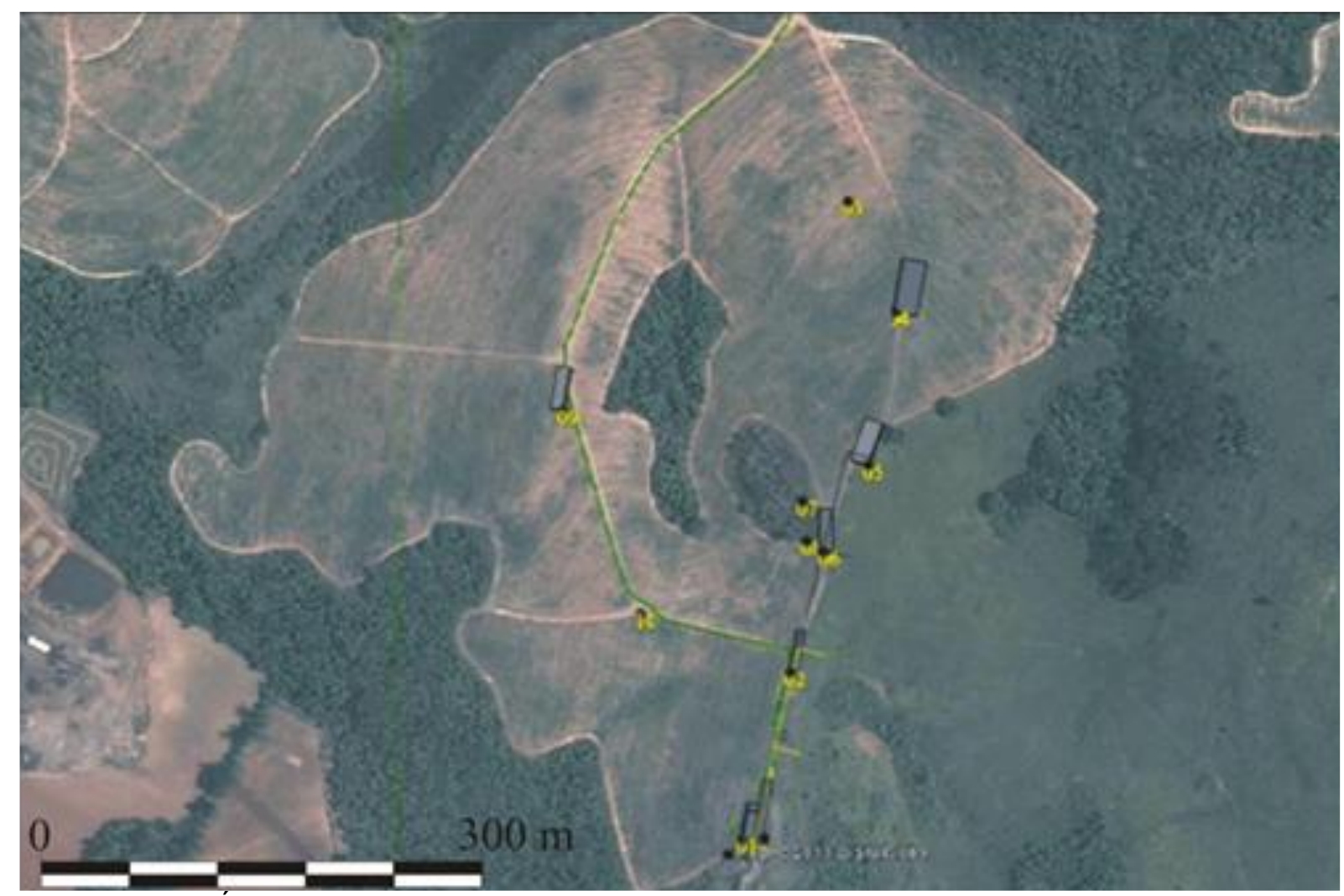

Figura 26 - Área-alvo com afloramentos de minério de manganês (NAP.Mineração/USP, 2014).

Os pontos identificados e representados na figura 26 confirmam 0 comportamento estrutural encontrado em campo e na bibliografia disponível. A visita e o mapeamento destas áreas foram de grande importância para o entendimento do comportamento da geometria geral dos corpos, especialmente as áreas parcialmente lavradas, com ótimas exposições do minério essenciais para o adensamento de medidas de atitudes que compõe um trabalho de natureza estrutural.

O mapeamento realizado na área permitiu a identificação de um afloramento de uma rocha quartzo-feldspática com granada e manganês. Esta rocha apresenta uma deformação que reflete o modelo proposto para a investigação geológica. Trata-se de uma dobra recumbente com um flanco estirado (Figura 27). O comportamento estrutural das porções estiradas e 
seccionadas (Figura 28) pode representar os corpos de manganês encontrados no sinforme. Em profundidade, o caráter sigmoidal das estruturas se mantém (Figura 29), por vezes seccionado por falhas (Figura 30). A figura 31 ilustra o aspecto das dobras recumbentes na área de estudo.

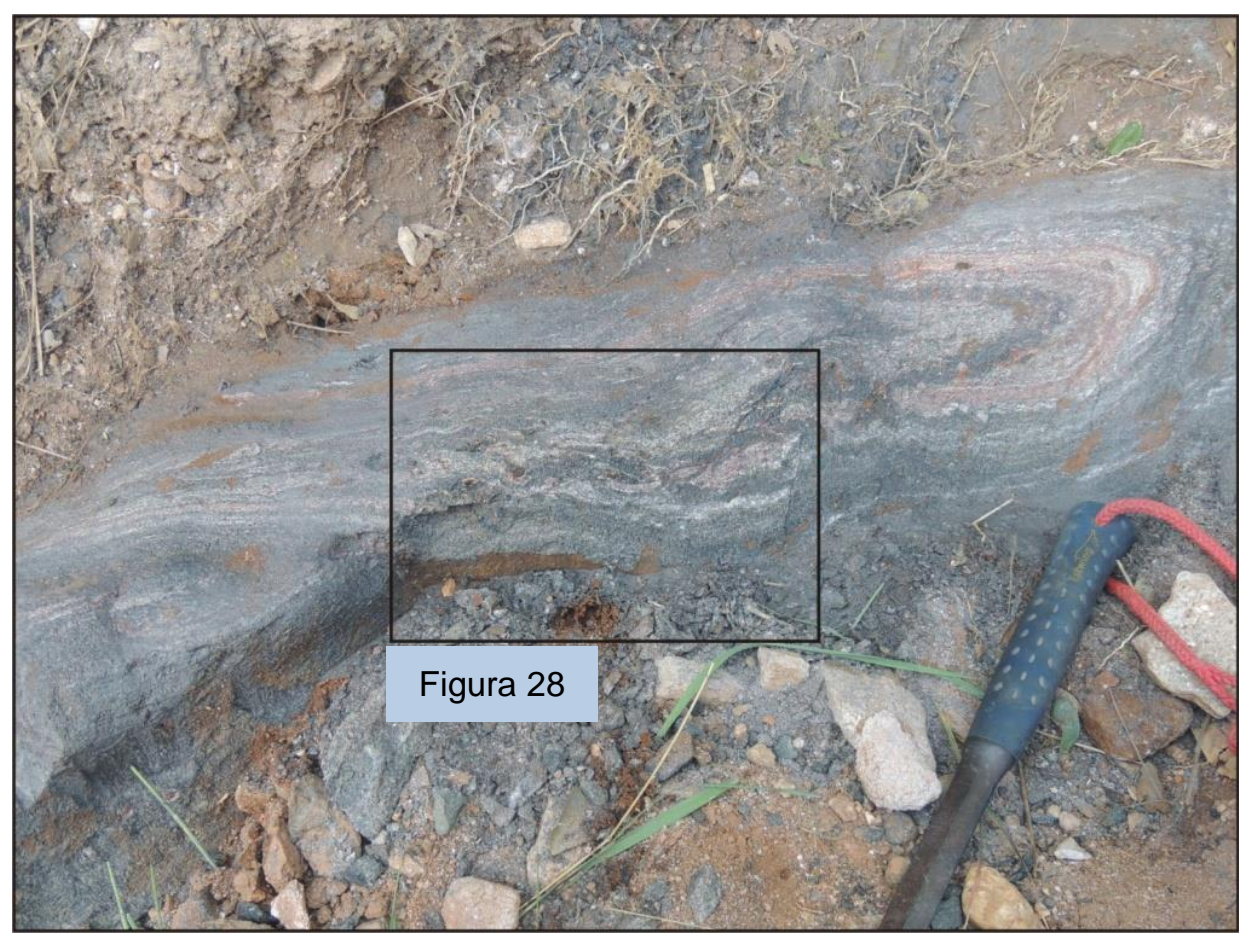

Figura 27 - Dobramento em escala local refletindo o comportamento estrutural regional. No retângulo em destaque o detalhe da figura 30. (NAP.Mineração/USP, 2014).

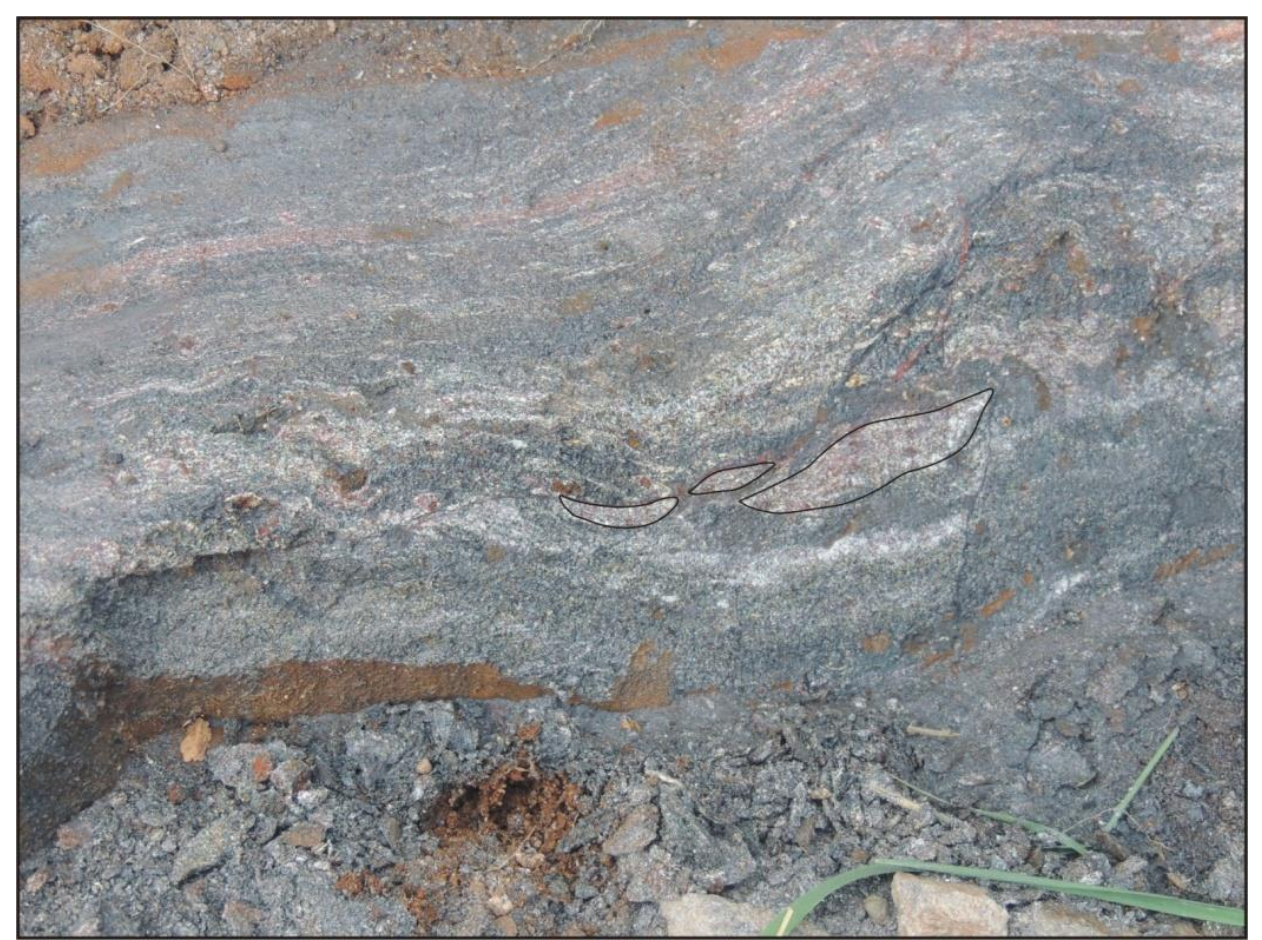

Figura 28 - Porções seccionadas da estrutura dobrada. (NAP.Mineração/USP, 2014). 


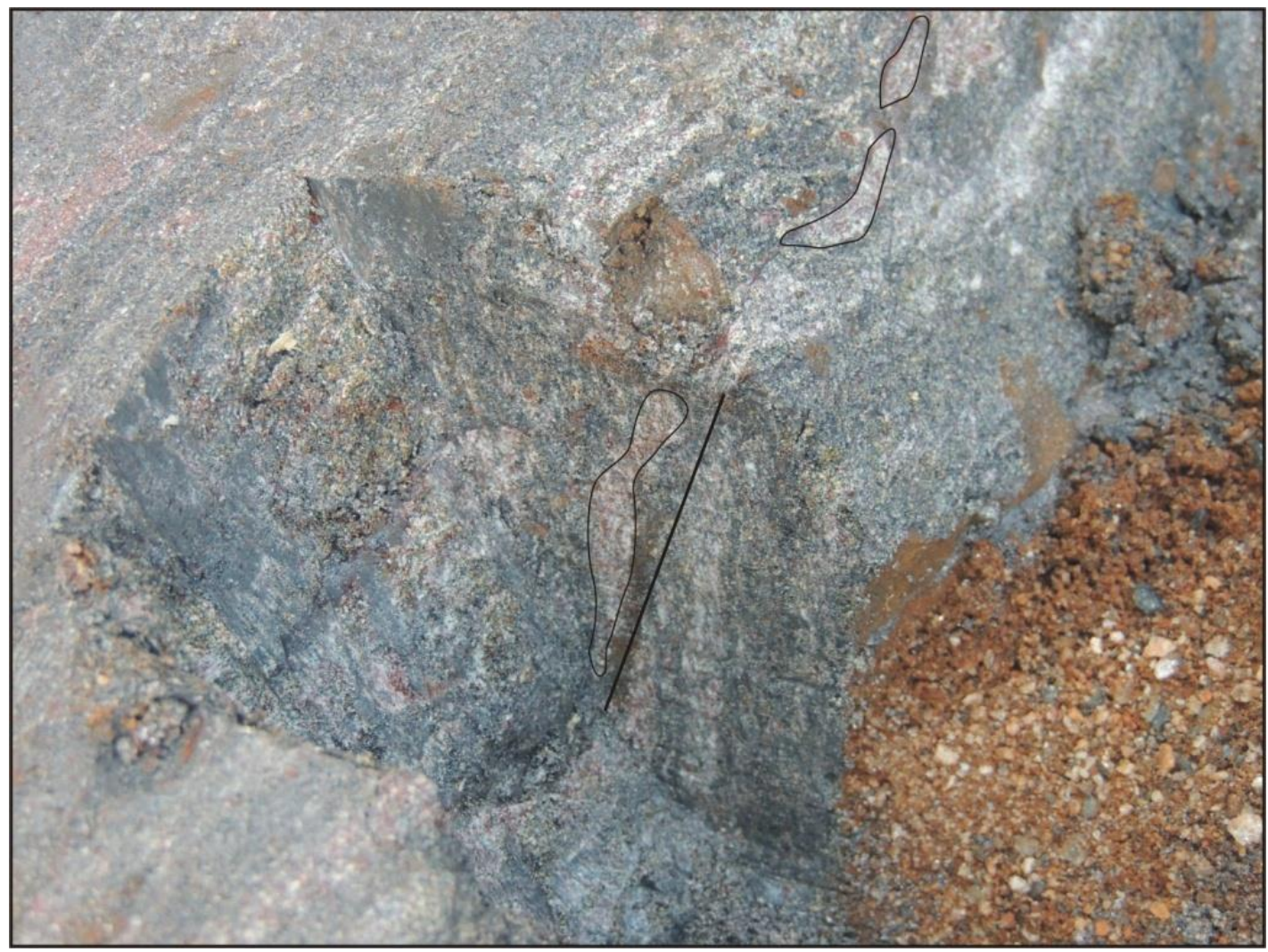

Figura 29 - Corte transversal no afloramento mostrando o comportamento dos segmentos em profundidade. (NAP.Mineração/USP, 2014).

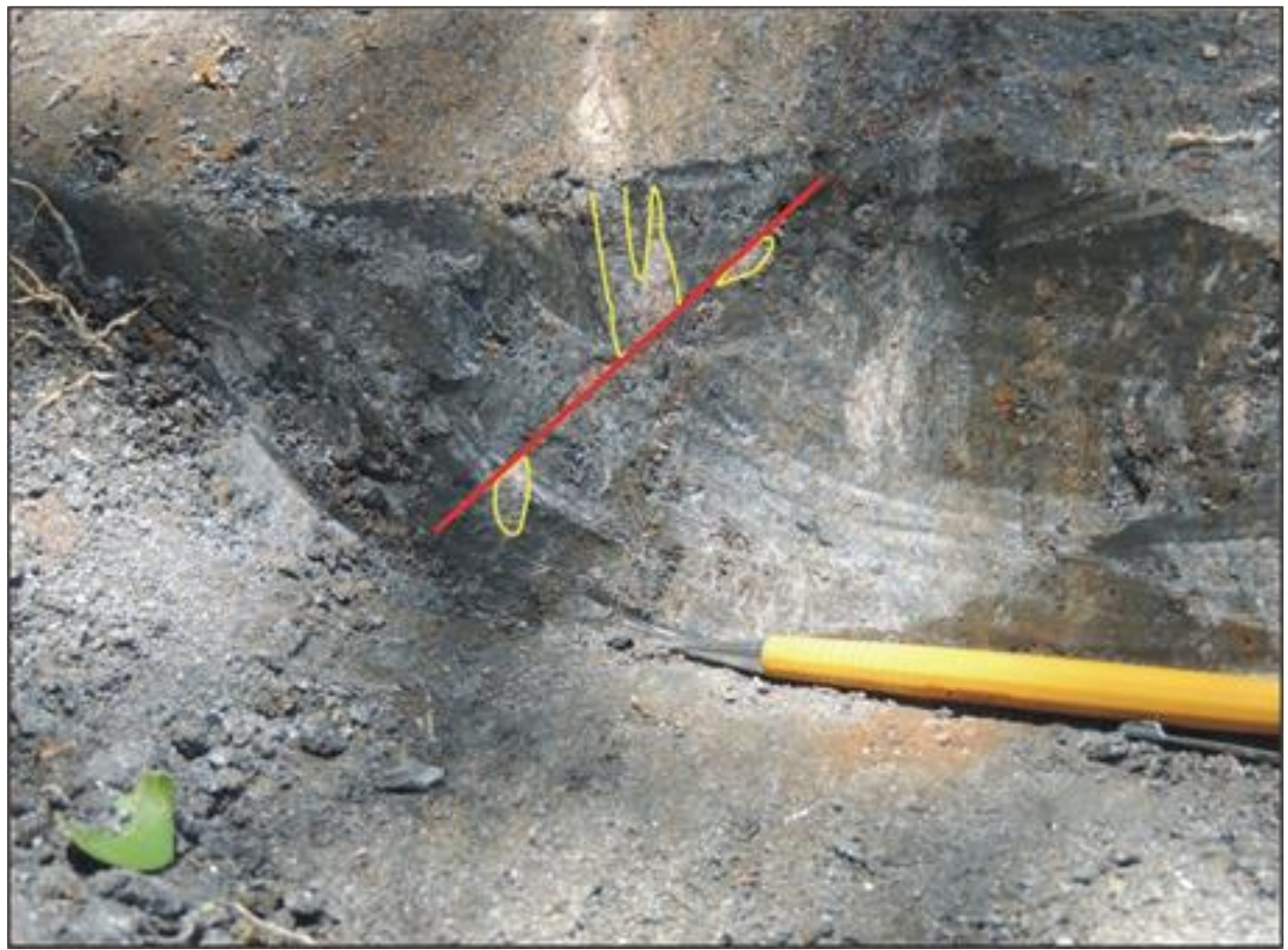

Figura 30 - Seção de um sigmoide seccionado por falha. (NAP.Mineração/USP, 2014). 


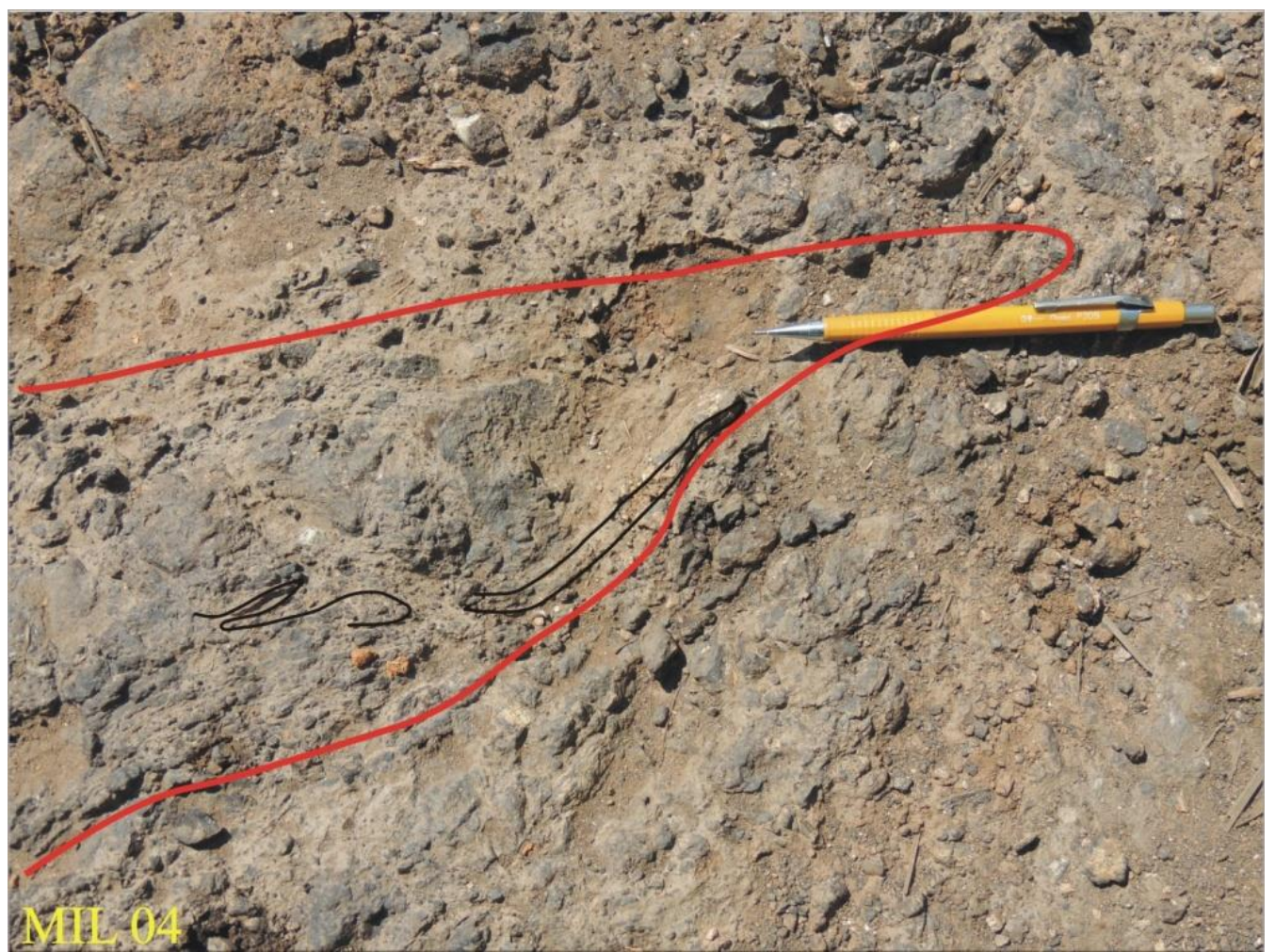

Figura 31 - Aspecto das dobras recumbentes. (NAP.Mineração/USP, 2014).

O mapeamento geoestrutural gerou um modelo conceitual do depósito de manganês na Fazenda Santana conforme a figura 32.

afloramento

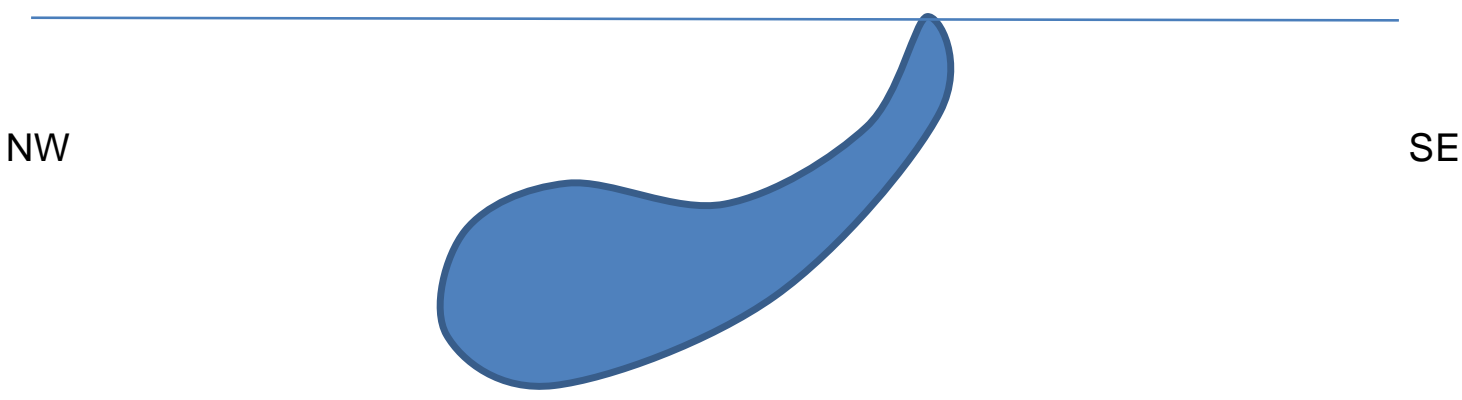

depósito com perfil sigmoidal

Figura 32 - Modelo conceitual do depósito de manganês da Fazenda Santana.

(NAP.Mineração/USP, 2014). 


\subsubsection{Levantamento Geofísico}

Um levantamento geofísico foi conduzido para obtenção das profundidades e espessuras aproximadas da camada mineralizada, e verificar se há evidências da existência de um depósito possivelmente viável na área. Com os dados obtidos pelo levantamento topográfico e mapeamento geoestrutural, foram definidos os pontos e perfis onde os ensaios geofísicos foram realizados.

O método utilizado para a obtenção de dados geofísicos foi o da eletrorresistividade. A eletrorresistividade pode ser definida como sendo uma medida da dificuldade com a qual a corrente elétrica se propaga através de um determinado material. De acordo com informações previamente obtidas, a camada rica em manganês no depósito apresenta valores de resistividade mais baixos do que os do solo e os da rocha encaixante.

As técnicas escolhidas foram a de Sondagem Elétrica Vertical (SEV) e a de Caminhamento Elétrico (CE). Foram planejados e realizados ensaios de SEV em 4 pontos, e de CE por 5 perfis na área-alvo. A figura 33 mostra os pontos dos ensaios de SEV e os perfis dos ensaios de CE realizados. Esses ensaios resultaram nos perfis apresentados na figura 34.

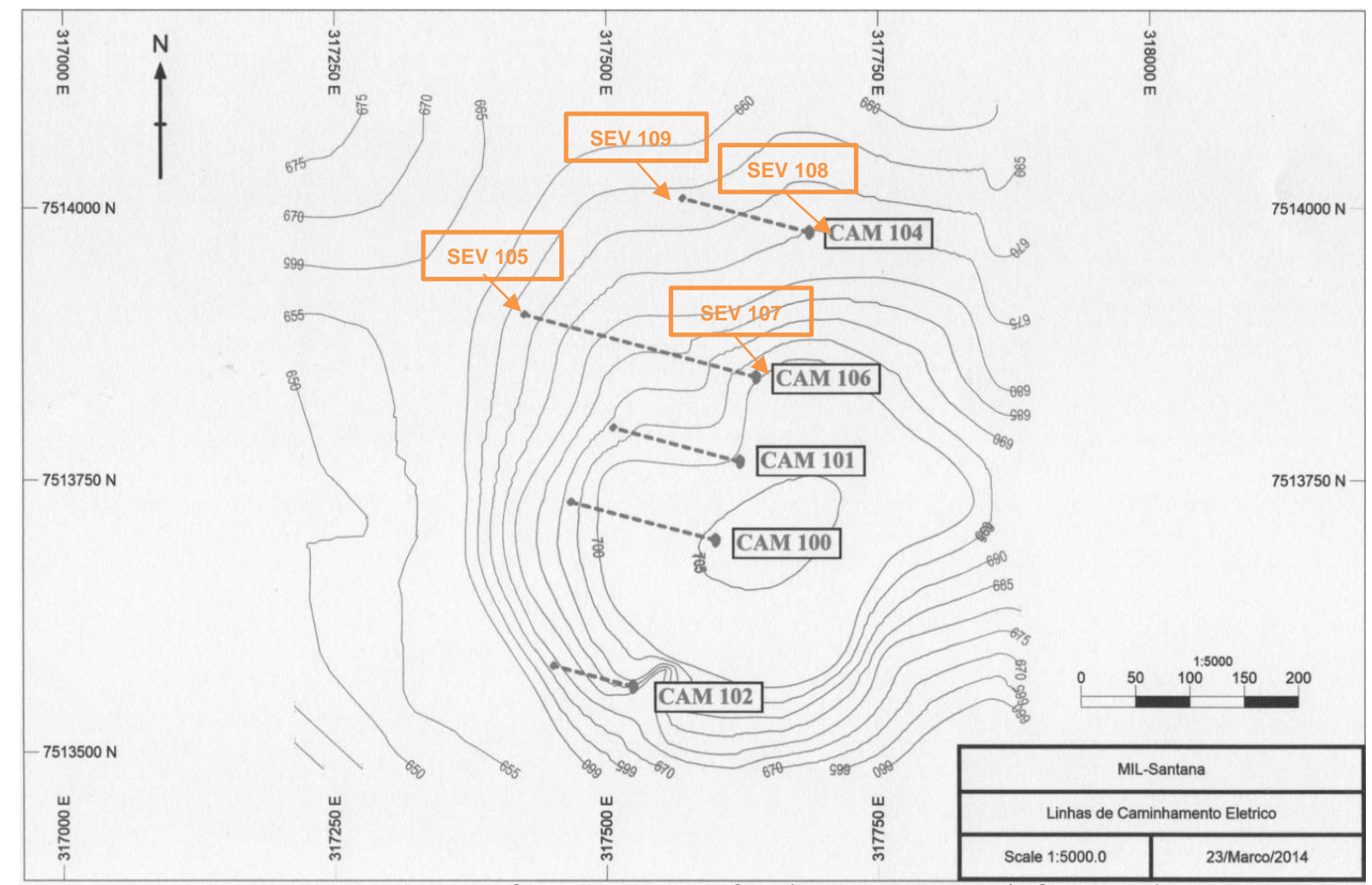

Figura 33 - Pontos de SEV e linhas de CE. (NAP.Mineração/USP, 2014). 


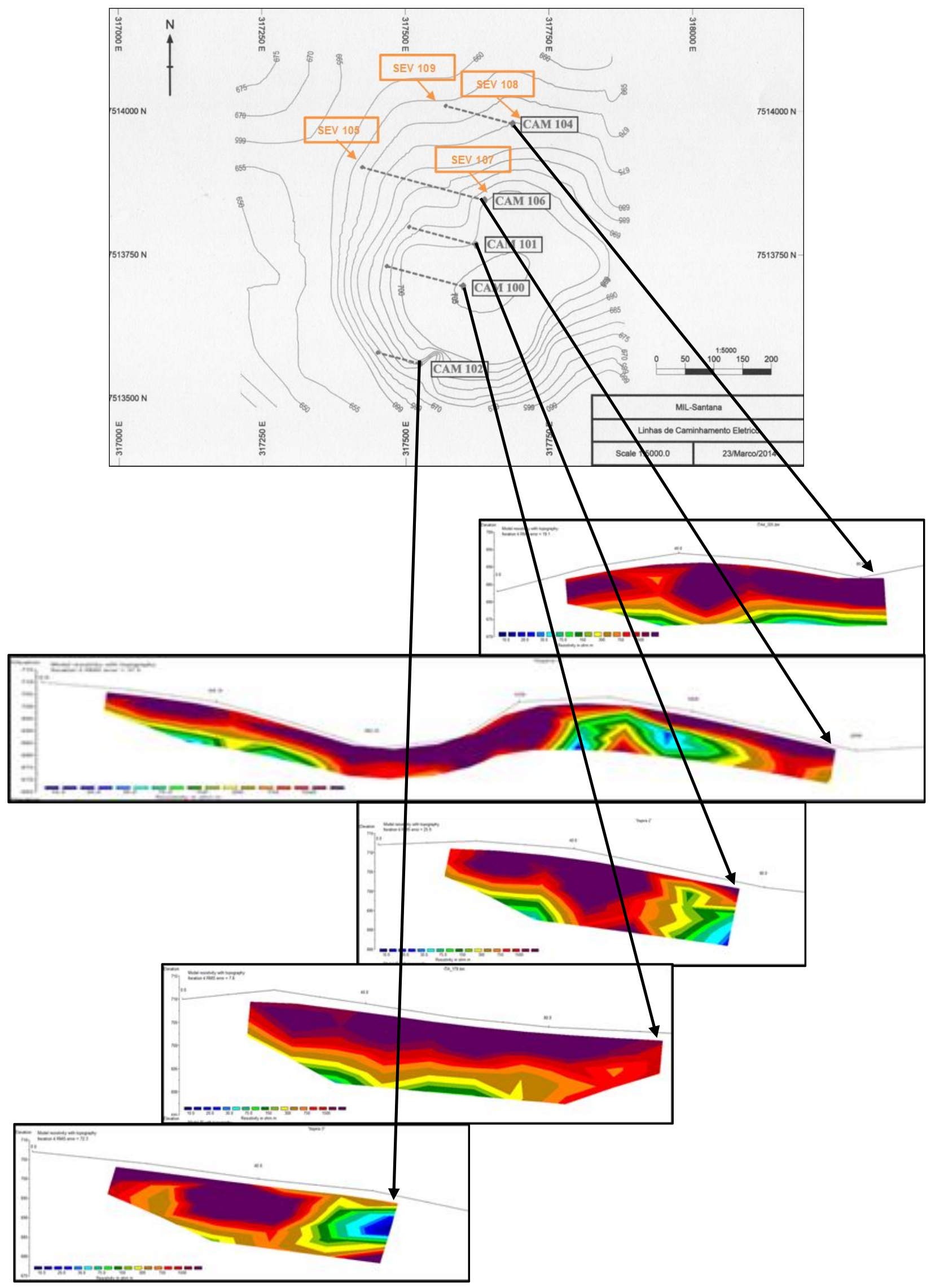

Figura 34 - Perfis elaborados com base nos dados obtidos através dos ensaios. 
Os resultados dos ensaios de SEV, conforme a tabela 5 abaixo, indicam que a espessura da camada mineralizada pode ultrapassar 10 metros, e a profundidade pode passar de 40 metros.

Tabela 5 - Dados da SEV para profundidade e espessura das camadas. (NAP.Mineração/USP, 2014).

\begin{tabular}{|c|c|c|c|c|}
\hline \multirow{2}{*}{ nocias } & \multirow{2}{*}{ BHID } & \multirow{2}{*}{ From } & \multirow{2}{*}{ To } & \multirow{2}{*}{ LITOLOGIA } \\
\hline & & & & \\
\hline \multirow[t]{5}{*}{ SEV 105} & S-01 & 0 & 0,6 & Solo alteração \\
\hline & S-01 & 0,6 & 1,1 & Solo alteração \\
\hline & $\mathrm{S}-01$ & 1,1 & 10,0 & Rocha alterada \\
\hline & S-01 & 10,0 & 35,0 & Rocha alterada \\
\hline & S-01 & 35,0 & & Manganês \\
\hline \multirow[t]{4}{*}{ SEV 107} & $\mathrm{~S}-02$ & 0 & 0,7 & Solo alteração \\
\hline & $\mathrm{S}-02$ & 0,7 & 9,8 & Solo alteração \\
\hline & $\mathrm{S}-02$ & 9,8 & 28,0 & Rocha alterada \\
\hline & $\mathrm{S}-02$ & 28,0 & & Manganês \\
\hline \multirow[t]{4}{*}{ SEV 108} & $\mathrm{~S}-03$ & 0 & 0,6 & Solo alteração \\
\hline & S-03 & 0,6 & 13,5 & Solo alteraçãd \\
\hline & $\mathrm{S}-03$ & 13,5 & 18,6 & Rocha alt \\
\hline & $\mathrm{S}-03$ & 18,6 & 29,0 & Nanganites \\
\hline \multirow[t]{5}{*}{ SEV 109} & S-04 & 0 & 0,5 & Solo alteração \\
\hline & S-04 & 0,5 & 6,6 & Solo alteração \\
\hline & $\mathrm{S}-04$ & & 42 & rada \\
\hline & S-04 & & 55,0 & ivlanganês \\
\hline & $\mathrm{S}-04$ & 55,0 & & Rocha sã \\
\hline
\end{tabular}

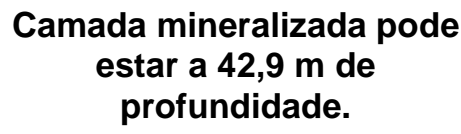

\section{Camada mineralizada com} $10,4 \mathrm{~m}$ de espessura.

\section{Camada mineralizada com} $12,1 \mathrm{~m}$ de espessura.

Nos ensaios de CE também foi identificada a camada de baixa resistividade que sugere a zona mineralizada. Essa camada é representada por resistividades menores que 200 ohm.m.

As seções dos ensaios de CE indicam que a espessura da camada pode chegar ou ultrapassar 10 m, e que parte expressiva do depósito pode ser encontrada em profundidades não superiores a 15 metros.

Os dados de profundidades e espessuras das camadas obtidos através dos ensaios de SEV e CE reforçam as evidências da ocorrência de um depósito de manganês economicamente viável. 


\subsubsection{Modelo Geológico Preliminar}

O levantamento topográfico e o mapeamento geoestrutual indicam que os corpos na região manganesífera de Itapira podem ser extremamente deformados e boudinados, suportando altos topográficos, e estão alinhados no eixo NE-SW. A análise geoestrutural indicou que o formato da seção vertical do depósito deve ser sigmoidal (Figura 34). Os dados obtidos através dos ensaios de SEV e CE indicam que parte expressiva da camada de manganês da Fazenda Santana deve ser encontrada entre 0 metro (afloramento) e 15 metros de profundidade, e que a espessura da camada pode chegar ou ultrapassar 10 metros. As figuras 34 a 37 representam o modelo geológico preliminar gerado.

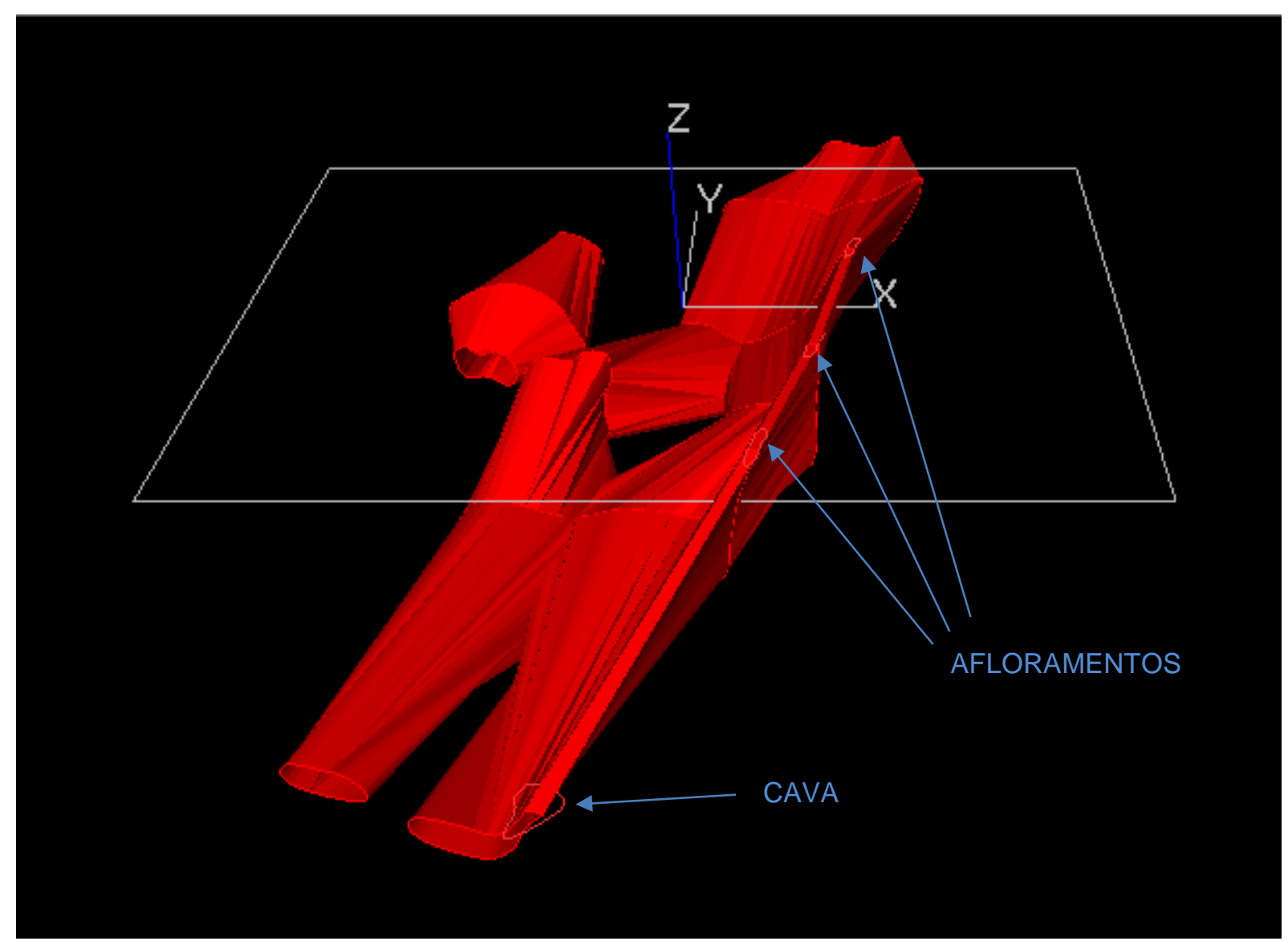

Figura 35 - Depósito disposto em função dos eixos x, y e z, se afastando para NE.

(NAP.Mineração/USP, 2014). 


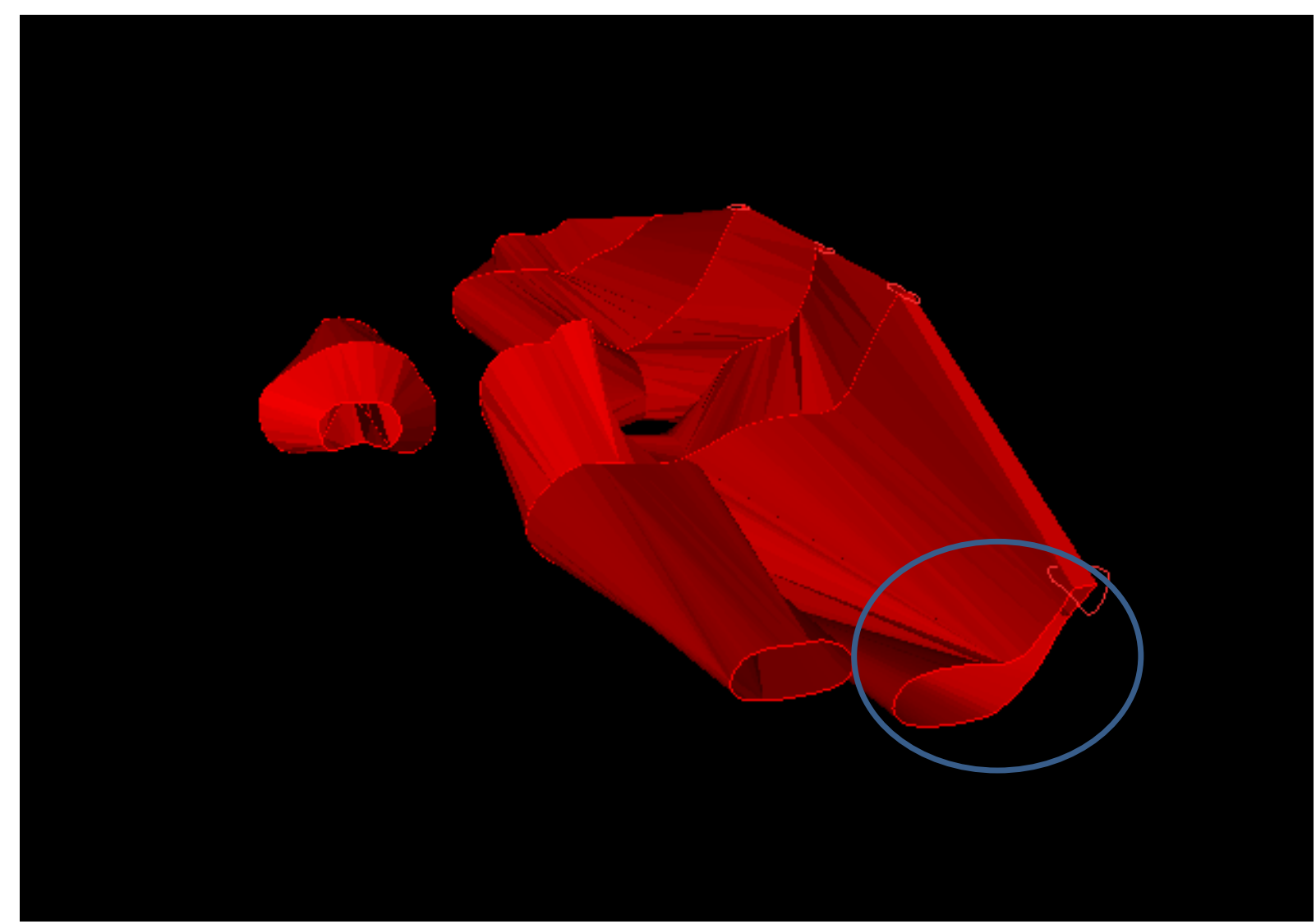

Figura 36 - Depósito se afastando para NE. Em detalhe o perfil sigmoidal. (NAP.Mineração/USP, 2014).

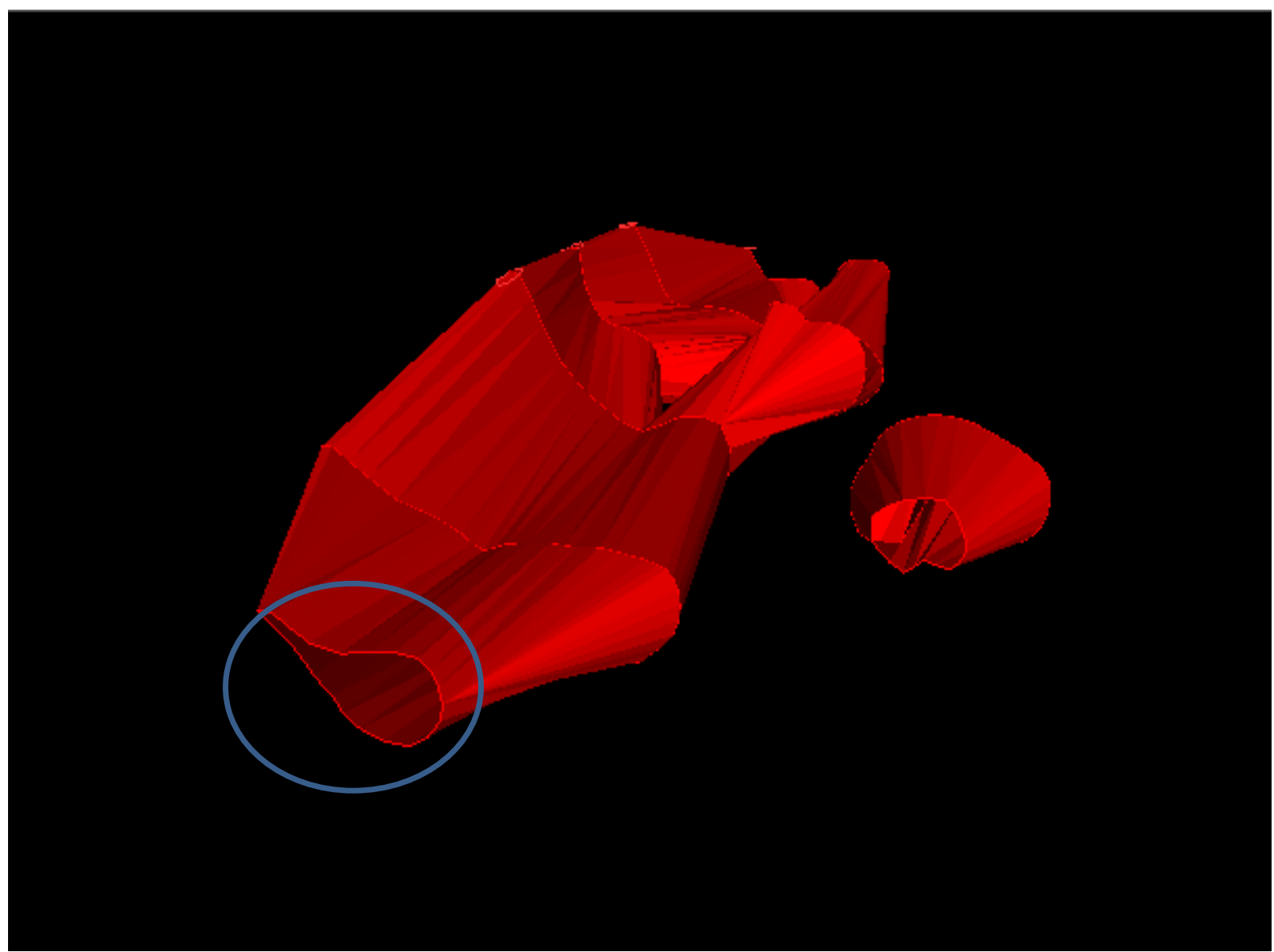

Figura 37 - Depósito se afastando para SW. Em detalhe o perfil sigmoidal. (NAP.Mineração/USP, 2014). 


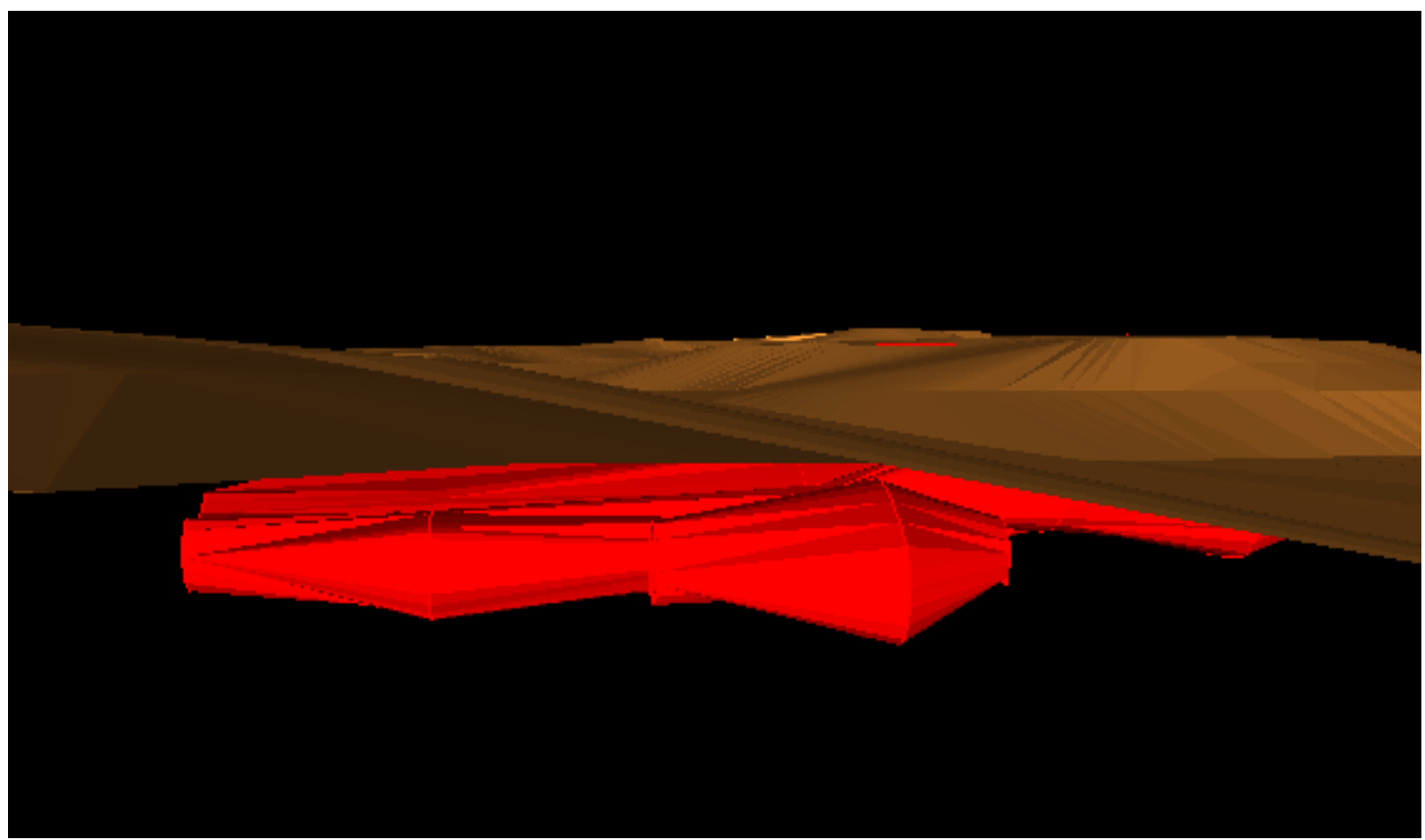

Figura 38 - Depósito sob a superfície e afloramento, vista no sentido SE. (NAP.Mineração/USP, 2014).

Com simulação de bancadas de lavra em cava conceitual podemos visualizar o modelo preliminar do depósito parcialmente exposto na superfície (Figuras 38 e 39).

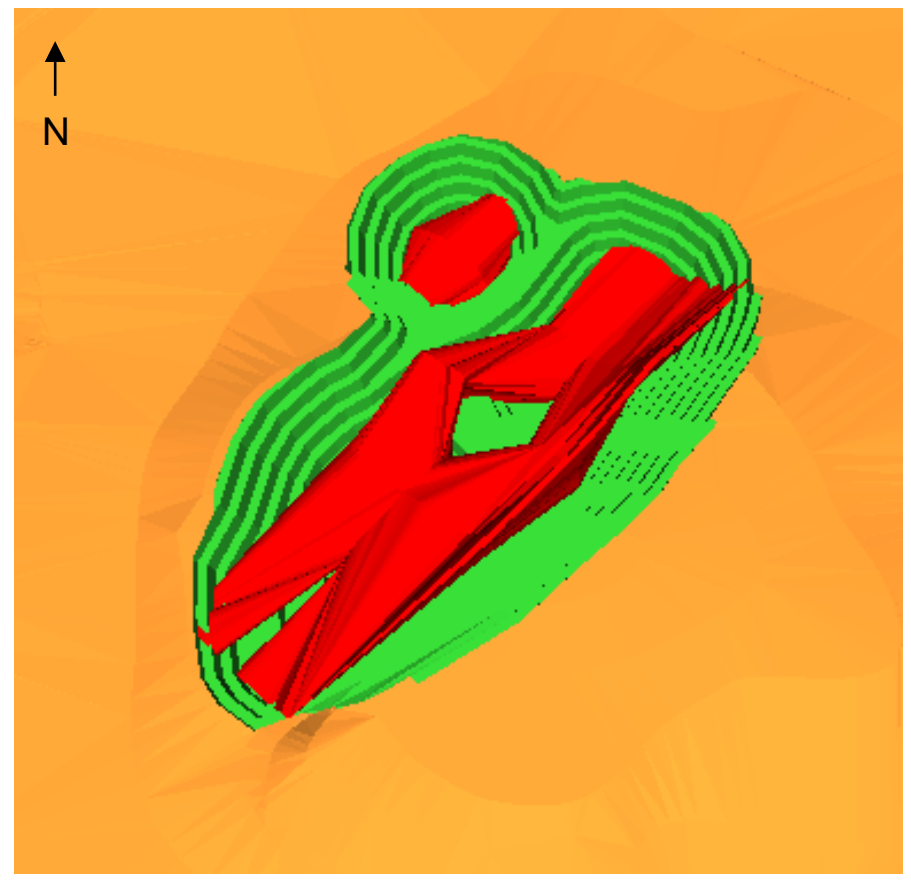

Figura 39 - Modelo preliminar do depósito em cava conceitual. (NAP.Mineração/USP, 2014). 


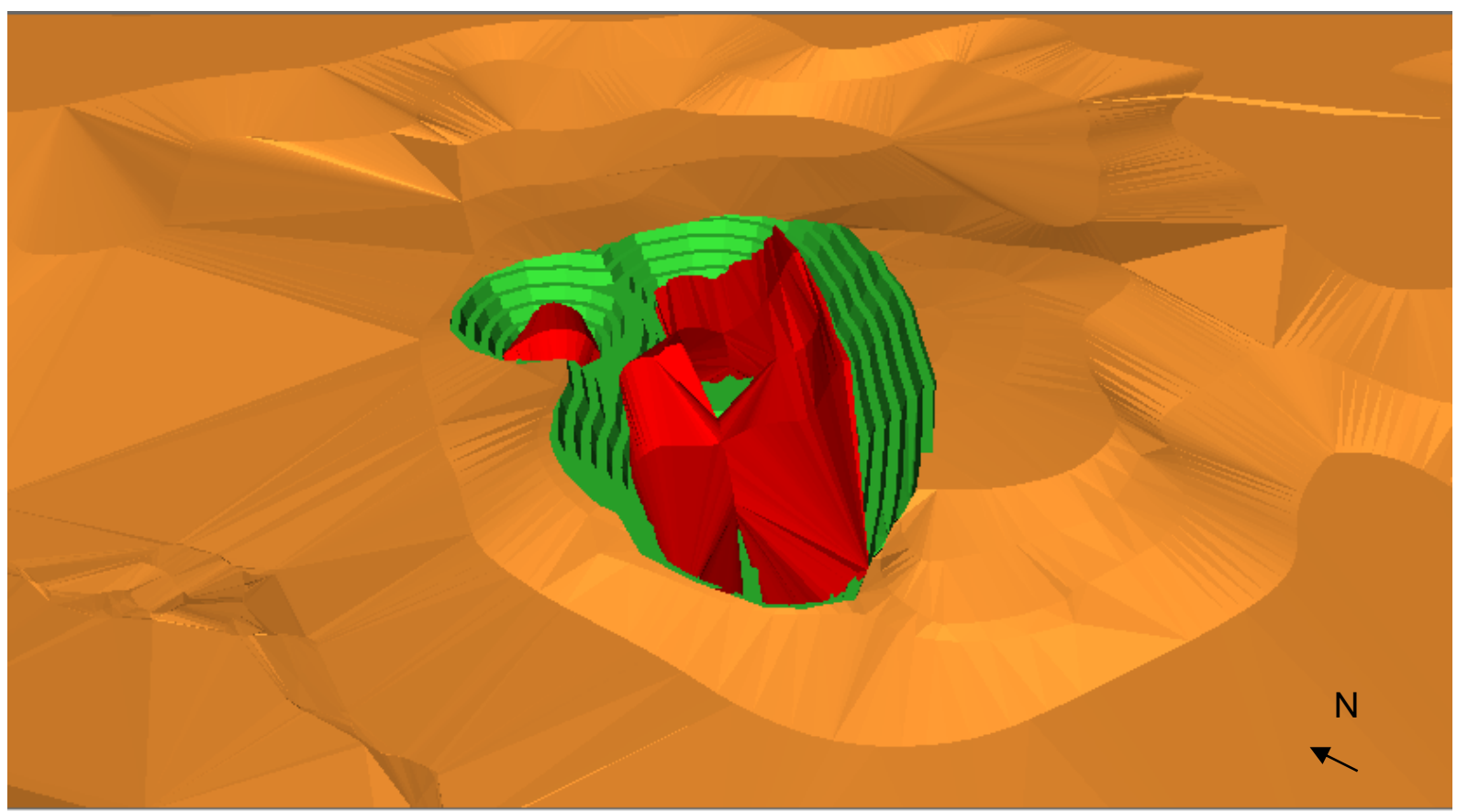

Figura 40 - Modelo preliminar do depósito em cava conceitual. (NAP.Mineração/USP, 2014).

\subsubsection{Plano de Sondagem}

Com base nos dados obtidos nesse trabalho, foi elaborado um plano de sondagem, com furos executados com mergulho vertical e profundidade prevista para cada furo entre 60 a 100 metros, de acordo com a morfologia conceitual do modelo geológico preliminar elaborado. A campanha inclui duas fases de trabalhos, com um total de 1.660 metros de sondagem (Figura 40).

- Fase 1: malha aproximada de $150 \mathrm{~m}$ x $50 \mathrm{~m}$, com linhas paralelas coincidentes com as linhas do CE, com 10 furos e comprimento total estimado de 780 metros de sondagem (Tabela 6, Figura 41).

- Fase 2: malha 'in-fill' de aproximadamente $75 \mathrm{~m}$ x $50 \mathrm{~m}$, com linhas paralelas e intercaladas à malha inicial, com 12 furos e comprimento total estimado de 880 metros de sondagem (Tabela 7, Figura 42).

A tabela 6 apresenta as coordenadas das sondagens propostas para a Fase 1, assim como a profundidade e espessura estimadas para a ocorrência de minério de manganês, conforme a morfologia conceitual do modelo geológico preliminar elaborado. 


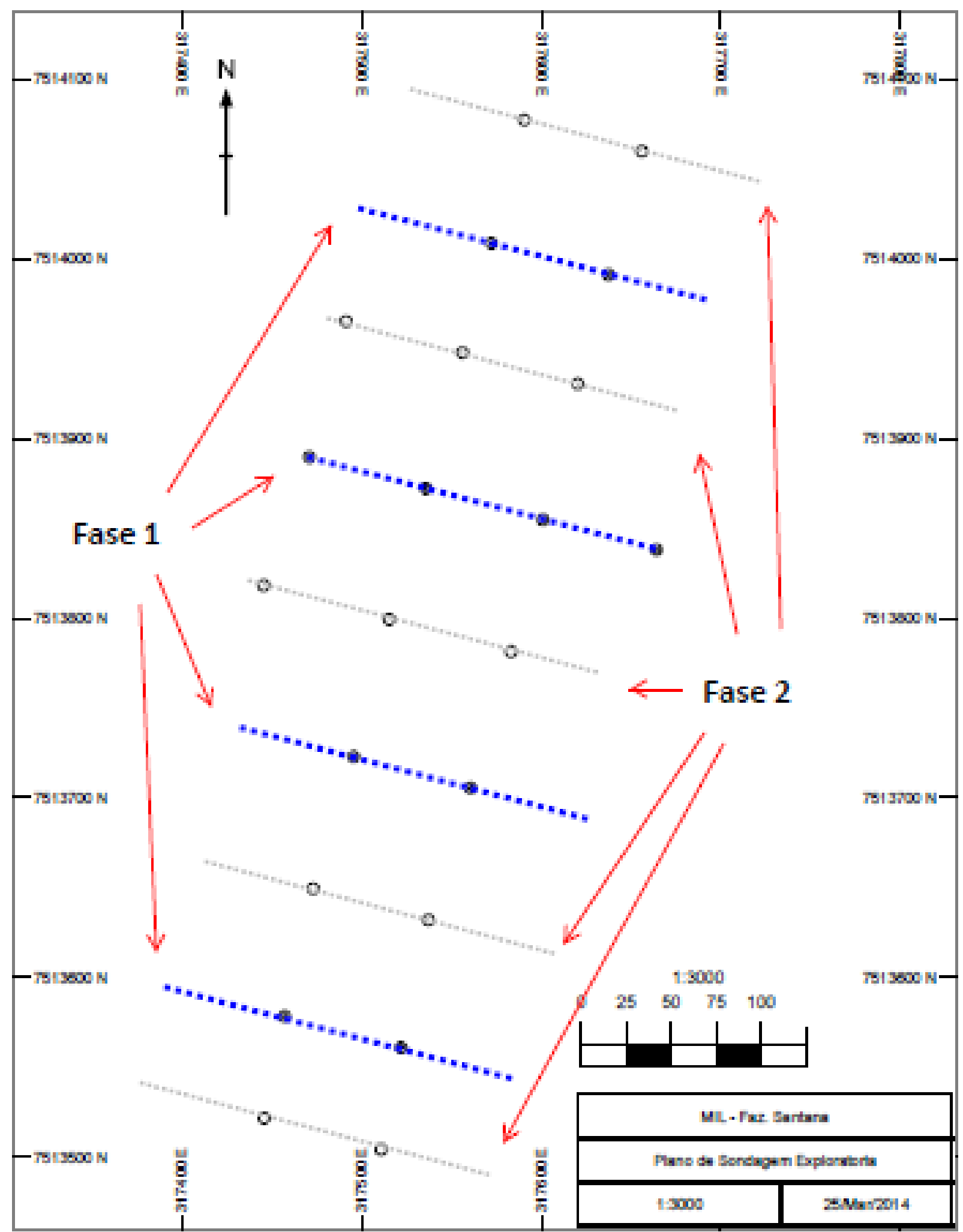

Figura 41 - Plano geral de sondagem para a área-alvo. (NAP.Mineração/USP, 2014). 
Tabela 6 - Fase 1 do plano de sondagem. (NAP.Mineração/USP, 2014).

\begin{tabular}{|c|c|c|c|c|c|c|c|}
\hline \multicolumn{8}{|c|}{ MIL-Santana: Plano de Sondagem Exploratória (Fase 1) } \\
\hline \multirow{2}{*}{ Furo } & \multirow{2}{*}{ Perfil } & \multicolumn{3}{|c|}{ Coordenadas Colar (m) $\left(^{*}\right)$} & \multicolumn{2}{|c|}{ Manganês (**) } & \multirow{2}{*}{$\begin{array}{c}\text { Prof. } \\
\text { Total (m) }\end{array}$} \\
\hline & & $\mathbf{X}$ & $\mathbf{Y}$ & $\mathbf{Z}$ & Prof. (m) & Espess. (m) & \\
\hline SAN-10-01 & 10 & 317522 & 7513560 & 684 & 27 & 15 & 60 \\
\hline SAN-10-02 & 10 & 317457 & 7513578 & 675 & 5 & 12 & 60 \\
\hline SAN-20-01 & 20 & 317561 & 7513705 & 704 & 38 & 35 & 90 \\
\hline SAN-20-02 & 20 & 317495 & 7513722 & 701 & 40 & 35 & 90 \\
\hline SAN-30-01 & 30 & 317664 & 7513837 & 700 & 35 & 10 & 80 \\
\hline SAN-30-02 & 30 & 317601 & 7513854 & 690 & 46 & 30 & 80 \\
\hline SAN-30-03 & 30 & 317536 & 7513872 & 683 & 50 & 10 & 80 \\
\hline SAN-30-04 & 30 & 317471 & 7513889 & 677 & 26 & 34 & 80 \\
\hline SAN-40-01 & 40 & 317637 & 7513991 & 671 & 34 & 30 & 80 \\
\hline SAN-40-02 & 40 & 317572 & 7514998 & 667 & 35 & 25 & 80 \\
\hline & & & & & \multicolumn{2}{|c|}{ Total Estimado (m): } & 780 \\
\hline
\end{tabular}

Figura 42 - Fase 1 do plano de sondagem. (NAP.Mineração/USP, 2014).

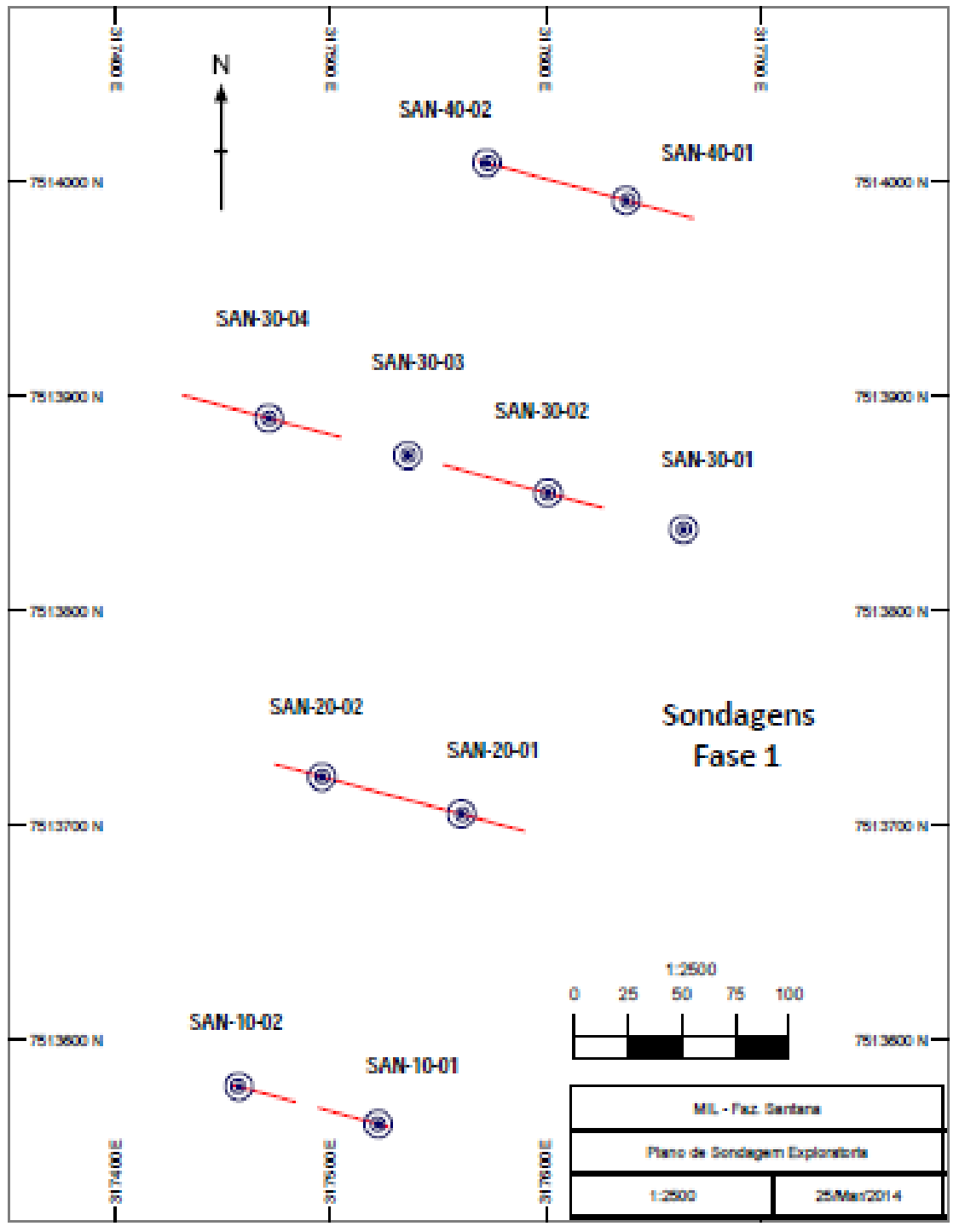


A tabela 5 apresenta as coordenadas das sondagens propostas para a Fase 2, assim como a profundidade e espessura estimadas para a camada mineralizada.

Tabela 7 - Fase 2 do plano de sondagem (NAP.Mineração/USP, 2014).

\begin{tabular}{|c|c|c|c|c|c|c|c|}
\hline \multicolumn{7}{|c|}{ MIL-Santana: Plano de Sondagem Exploratória (Fase 2) } \\
\hline \multirow{2}{*}{ Furo } & \multirow{2}{*}{ Perfil } & \multicolumn{2}{c|}{ Coordenadas Colar (m) } & \multicolumn{2}{c|}{ Manganês } & $\begin{array}{c}\text { Prof. } \\
\text { Total (m) }\end{array}$ \\
\cline { 3 - 7 } & & $\mathbf{X}$ & $\mathbf{Y}$ & $\mathbf{Z}$ & Prof. (m) & Espess. (m) & 60 \\
\hline SAN-05-01 & 05 & 317511 & 7513504 & 668 & 40 & 10 & 60 \\
\hline SAN-05-02 & 05 & 317445 & 7513521 & 660 & 31 & 10 & 80 \\
\hline SAN-15-01 & 15 & 317537 & 7513631 & 703 & 46 & 20 & 80 \\
\hline SAN-15-02 & 15 & 317473 & 7513649 & 692 & 30 & 20 & 80 \\
\hline SAN-25-01 & 25 & 317583 & 7513781 & 698 & 41 & 25 & 80 \\
\hline SAN-25-02 & 25 & 317515 & 7513799 & 692 & 22 & 39 & 80 \\
\hline SAN-25-03 & 25 & 317445 & 7513818 & 678 & 30 & 10 & 80 \\
\hline SAN-35-01 & 35 & 317620 & 7513930 & 677 & 35 & 30 & 80 \\
\hline SAN-35-01 & 35 & 317556 & 7513947 & 672 & 45 & 20 & 80 \\
\hline SAN-35-01 & 35 & 317491 & 7513964 & 671 & 40 & 10 & 60 \\
\hline SAN-45-01 & 45 & 317656 & 7514059 & 665 & 38 & 10 & 60 \\
\hline SAN-45-02 & 45 & 317591 & 7514077 & 659 & 34 & 10 & 880 \\
\hline
\end{tabular}

Figura 43 - Fase 2 do plano de sondagem. (NAP.Mineração/USP, 2014).

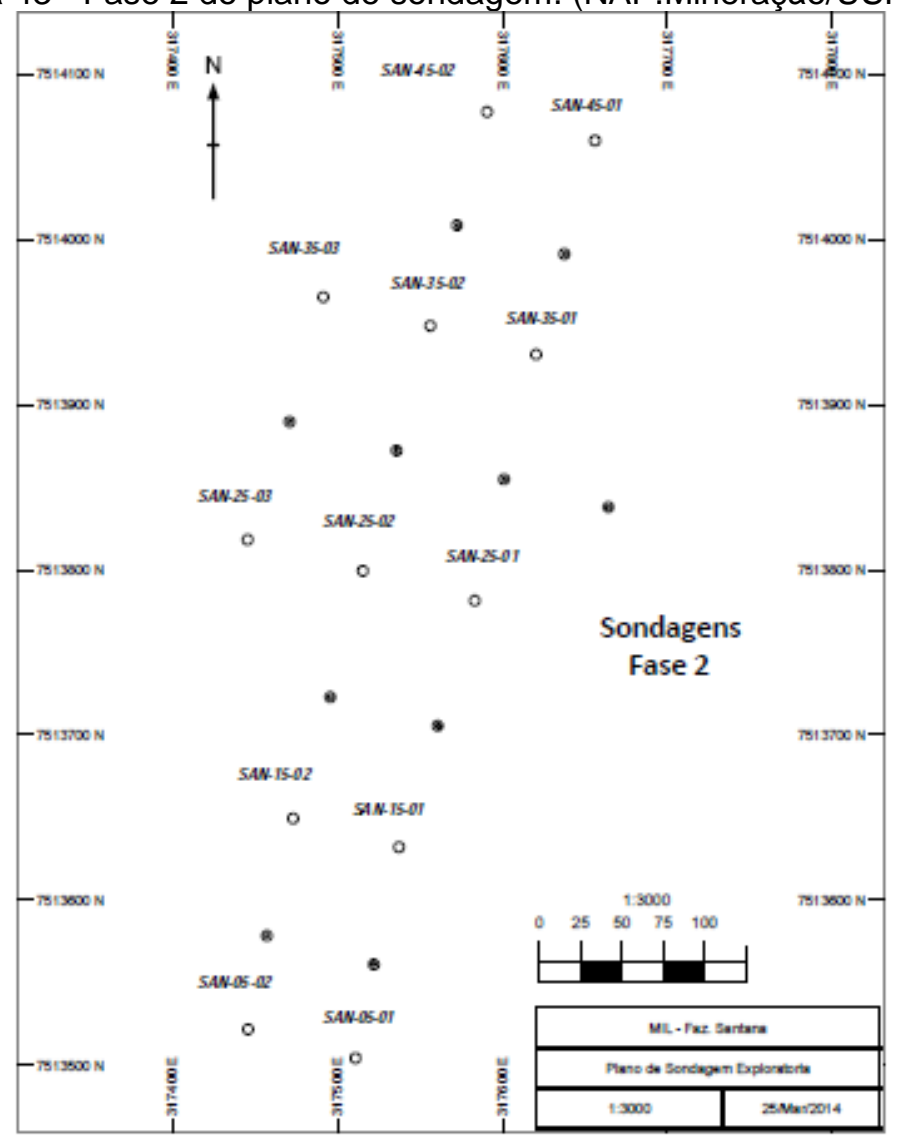




\subsubsection{Aplicação da Matriz CEBIm}

O objetivo de gerar um modelo preliminar do depósito de manganês na área prospectada foi alcançado.A interpretação dos dados obtidos em campo e a análise do modelo geológico preliminar gerado indicam que há evidências da ocorrência de um depósito de manganês cuja extração pode ser economicamente viável. No entanto, o nível de conhecimento da jazida para estimativa de recurso e reserva mineral é limitado. Informações mais precisas sobre a distribuição espacial dos teores de Mn e a caracterização tecnológica do minério podem ser obtidas através da análise de testemunhos de furos de sondagem. Foi recomendada uma campanha de sondagem para elaboração de uma caracterização geológica suficientemente sólida para controle e gerenciamento das incertezas e riscos de caráter geológico.

Os níveis de implementação de cada atividade das melhores práticas nessa pesquisa mineral foram estimados e inseridos na Matriz CEBIm, obtendo o índice CEBIm 6.9 (Figura 43).

1. Pesquisa projetada e conduzida por Pessoa Qualificada:

2. Premissas geológicas apoiadas por dados de campo e abordagem científica:

3. Programa de controle de qualidade aplicado à aquisição de dados:

4. Métodos aplicados e os dados obtidos devidamente registrados:

5. Amostragem realizada com base científica:

6. Métodos de perfuração adequados:

7. Amostras gerenciadas com a devida segurança: 1

8. Preparação das amostras adequada: 1

9. Análise das amostras realizada por laboratório de boa reputação: 1

10. Trabalhos conduzidos com enquadramento aos requisitos normativos: 5

\begin{tabular}{|c|c|c|c|c|c|c|c|}
\hline \multicolumn{2}{|c|}{ Itapira, SP } & Custo (C) & \multicolumn{2}{|c|}{ Esforço (E)Benefício (B) } & \multirow{2}{*}{$\begin{array}{c}\text { CEB } \\
\text { máx }=625\end{array}$} & \multirow{2}{*}{$\begin{array}{c}\text { Impl. (Im) } \\
>80 \%=5\end{array}$} & \multirow{2}{*}{$\begin{array}{l}\text { Índice } \\
\text { CEBIm }\end{array}$} \\
\hline & & máxC = 1 & máxE = 1 & máxB = 25 & & & \\
\hline \multicolumn{2}{|c|}{ Diretrizes } & mínC $=5$ & mínE = 5 & $\min B=5$ & mín=5 & $<20 \%=1$ & $(2-10)$ \\
\hline 1 & Pesquisa planejada e conduzida por Pessoa Qualificada & 3 & 4 & 25 & 300 & 5 & 1,1 \\
\hline 2 & Premissas geológicas apoiadas por dados de campo e abordagem científica & 4 & 4 & 25 & 400 & 5 & 1,5 \\
\hline 3 & Programa de controle de qualidade aplicado à aquisição de dados & 4 & 4 & 25 & 400 & 5 & 1,5 \\
\hline 4 & Métodos aplicados e os dados obtidos devidamente registrados & 4 & 4 & 25 & 400 & 5 & 1,5 \\
\hline 5 & Amostragem realizada com base científica & 2 & 2 & 25 & 100 & 1 & 0,1 \\
\hline 6 & Métodos de perfuração adequados & 1 & 1 & 25 & 25 & 1 & 0,0 \\
\hline 7 & Amostras gerenciadas com a devida segurança & 4 & 4 & 20 & 320 & 1 & 0,2 \\
\hline 8 & Preparação das amostras adequada & 4 & 3 & 20 & 240 & 1 & 0,2 \\
\hline 9 & Análise das amostras realizada por laboratório de boa reputação & 4 & 4 & 20 & 320 & 1 & 0,2 \\
\hline 10 & Trabalhos conduzidos com enquadramento aos requisitos normativos & 3 & 2 & 20 & 120 & 5 & 0,5 \\
\hline & & & & & & & $6,9)$ \\
\hline & & & & & & & \\
\hline
\end{tabular}

Figura 44 - Matriz CEBIm para pesquisa mineral em depósito de manganês em Itapira, SP. 


\section{RESULTADOS E DISCUSSÕES}

A Matriz CEBIm aplicada ao garimpo de ouro visitado pela equipe do NAP.Mineraçao/USP em Itaituba resulta em um índice CEBIm igual a 2.0, pois não há registro de trabalho de pesquisa que possa ser utilizado para controle e gerenciamento de risco geológico. O índice 2.0 representa um conhecimento geológico mínimo que apenas justifica o interesse dos titulares em manter os direitos minerários sobre a área. Sabe-se que a área se encontra em tradicional província aurífera e que já houve produção de ouro com resultado satisfatório no passado recente, e que furos de sonda indicaram ocorrência de ouro. Quase todo o valor que pode ser agregado ao projeto se encontra represado, e a recomendação é a de contratar um(a) QP para planejamento e implementação de um programa completo de pesquisa mineral.

A aplicação da Matriz CEBIm na pesquisa mineral realizada em Caetité resulta em um índice CEBIm igual a 5.2. A pesquisa realizada possibilitou um cálculo de recursos, mas com pouco rigor científico. Houve pouca aderência dos trabalhos realizados à melhores práticas de pesquisa mineral. Uma revisão do programa por um(a) QP, com o uso de métodos científicos e adequados para reduzir as incertezas associadas à caracterização geológica e avaliação geoquímica, deve agregar valor significativo ao projeto.

A Matriz CEBIm da pesquisa realizada em Itapira indica um índice CEBIm igual a 6.9. A campanha de sondagem programada, importante para reduzir significativamente as incertezas de volume e teor, não foi realizada. Portanto, apesar do alto nível de aderência das atividades de pesquisa mineral às melhores práticas, ainda falta informação suficiente para cálculo seguro dos recursos e definição das reservas. A matriz indica que pesquisa adicional, especialmente direcionada para a obtenção de amostragem representativa e análise de amostras, pode reduzir consideravelmente as incertezas associadas a volume e teores e agregar valor significativo ao projeto.

Os resultados mostram como a Matriz CEBIm pode ser útil na avaliação do nível de aderência da pesquisa mineral de um projeto de produção mineral às melhores práticas de pesquisa mineral, contribuindo com a análise do risco geológico e do potencial de valor represado no projeto. 


\section{CONCLUSÕES}

A pesquisa conduzida resultou nas seguintes conclusões:

- A pequena mineração é uma atividade que geralmente opera com poucos recursos, baixa mecanização e de maneira informal ou ilegal. Nesse segmento, os riscos geológicos, operacionais e mercadológicos, intrínsecos à mineração, são frequentemente somados à falta de estrutura adequada e à limitada observância à legislação e às melhores práticas. Portanto, os riscos na pequena mineração não são apenas os inerentes à atividade mineira, mas também aqueles associados a práticas inadequadas de gerenciamento de produção mineral.

- Em mineração, os maiores riscos estão associados à incerteza geológica. É necessário que as reservas de minério sejam determinadas com alto nível de segurança para que a viabilidade e a sustentabilidade do projeto de produção mineral sejam confirmadas. Como a pesquisa mineral em pequenos depósitos é normalmente pouco aderente às melhores práticas, o risco geológico é especialmente importante na pequena mineração. Com uma pesquisa mineral adequada, os riscos geológicos podem ser gerenciados com eficiência e um valor significativo pode ser adicionado ao valor total do projeto.

- A adoção das melhoras práticas de pesquisa mineral pode reduzir substancialmente os riscos na pequena mineração, e ser fundamental para o sucesso do empreendimento. Um profissional qualificado pode executar uma pesquisa mineral econômica e eficiente para determinar uma reserva mínima, possibilitando rápido retorno do investimento e possível replicação para continuidade da produção mineral.

- A Matriz CEBIm foi estruturada como instrumento para avaliação do nível de aderência de um projeto de pesquisa mineral às melhores práticas. Por possibilitar uma avaliação simples, rápida, econômica e prática, o uso dessa matriz pode ser especialmente útil na pequena mineração. Os resultados da aplicação da matriz em três projetos de produção mineral em pequena escala demonstraram que a Matriz CEBIm pode contribuir com o controle dos riscos geológicos, agregando valor ao projeto e colaborando para o desenvolvimento sustentável na pequena mineração e em seu entorno. 


\section{BIBLIOGRAFIA}

ABEDI, M.; NOROUZI, G. H. Integration of various geophysical data with geological and geochemical data to determine additional drilling for copper exploration. Journal of Applied Geophysics, v.83, p.35-45, 2012.

ANNELS, A. E. Mineral deposit evaluation: a practical approach. New York: Springer Science \& Business Media, 1992.

ARRUDA, F. Matriz de priorização CEB. [s.L.], 2015. Disponível em: http: //www.arrudaconsult.com.br. Acesso em: junho 2015.

BALL, R.; BROWN P. Risk and return from equity investments in the astralian mining industry: Jan. 1958-Febr. 1979. Australian Journal of Management, v. 5, n. 1-2, p. 45-66, 1980.

BÁRDOSSY, G.; FODOR, J. Traditional and new ways to handle uncertainty in geology. Natural Resources Research, v.10, n. 3, p. 179-187, 2001.

BATISTA, R.P. Relatório final de pesquisa positivo. Ibiassu: Prospex Minérios Ltda., 2011. **

BAURENS, S. Valuation of metals and mining companies, in collaboration with the University of Zürich, Swiis Bank Institute and Prof. Dr. T. Hens. Basinvest, 2010. Disponível em: http://ehrenworthsyme.com/casadeleon/Docs/ValuationofMining.pdf. Acesso em: junho 2015.

BOTIN GONZALEZ, J. A. et al. Real options: a tool for managing technical risk in a mine plan. In: SME ANNUAL MEETING AND EXHIBIT 2012, Seattle, WA. Meeting preprints. [s.L.]: Society for Mining, Metallurgy, and Exploration, 2012. p. 572-578,.

BOTÍN, J. A.; GUZMÁN, R. R.; SMITH, M. L. A methodological model to assist in the optimization and risk management of mining investment decisions. Dyna, v. 78, n. 170, p. 221-226, 2011.

BUXTON, A. Responding to the challenge of artisanal and small-scale mining. How can knowledge networks help. London: International Institute for Environment and Development, 2013. Disponível em: http://pubs.iied.org/pdfs/16532IIED.pdf. Acesso em: junho 2015.

CANADIAN MINING, METALLURGY AND PETROLEUM ASSOCIATION. Exploration best practices guidelines. [s.L.]: 2015. National Instrument 43-101.

CAPPONI, L. N. Introdução de parâmetros de controle de incertezas para planejamento de lavra. 2012. Dissertação (Mestrado) - Universidade Federal do Rio Grande do Sul, Porto Alegre, 2012. 
COMISSÃO BRASILEIRA DE RECURSOS E RESERVAS. O que é CBRR? Descreve a missão da Comissão. Brasília. Disponível em: <http://cbrr.org.br/o-que-e-cbrr/> Acesso em: 19 dez 2016.

COMMITTEE FOR MINERAL RESERVES. Welcome to CRIRSCO. London: International Council on Mining and Metals. Disponível em: <http://www.crirsco.com/welcome.asp> Acesso em: 19 dez 2016.

CONNOLLY, E.; ORSMOND, D. The mining industry: from bust to boom. [s.L.]: , Economic Analysis Department, Reserve Bank of Australia, 2011.

DAVID, M. Geostatistical ore reserve estimation. Amsterdam: Elsevier, 1982.

DIMITRAKOPOULOS, R. Stochastic optimization for strategic mine planning: a decade of developments. Journal of Mining Science, v.47, n. 2, p. 138-150, 2011.

DIMITRAKOPOULOS, R. G.; SABOUR, S. A. A. Evaluating mine plans under uncertainty: can the real options make a difference?. Resources Policy, v. 32, n. 3, p. 116-125, 2007.

EVATT, G. W.; SOLTAN, M. O.; JOHNSON, P. V. Mineral reserves under price uncertainty. Resources Policy, v. 37, n. 3, p. 340-345, 2012.

FARIA JUNIOR, A. et al. O impacto do tipo de amostragem no controle de qualidade na lavra. REM: Revista Escola de Minas, Ouro Preto, MG. v. 63, n. 2, p. 385-392, abr./jun. 2010.

FREITAS, S. et al. Risk Management Incorporated to life-of-mine planning at Sossego Copper Mine, Carajás, Brazil. Materials Science Forum, v. 805, p. 172-177, 2015.

GAMARRA CHILMAZA, F. Programa para la prevención y eliminación progresiva del trabajo infantil en la minería artesanal de oro en sudamérica: estudio sociolaboral en los centros poblados de la Rinconada y Cerro Lunar". Puno: International Labour Organization. 2005. Disponível em: http://redsocial. pe/IISOCIOLABORAL. pdf. Acesso em: junho 2015.

HENTSCHEL, T.; HRUSCHKA, F.; PRIESTER, M. Global report on artisanal and small-scale mining. Report commissioned by the Mining, Minerals and Sustainable Development of the International Institute for Environment and Development. Disponível em: http://www. iied. org/mmsd/mmsd_pdfs/asm_global_report_draft_jan02. Acesso em: agosto 2002.

KITA, J. et al. Airborne electromagnetics in Pilbara manganese exploration? A case study. ASEG Extended Abstracts, v. 2012, n. 1, p. 1-2, 2012.

KREUZER, O. P.; ETHERIDGE, M. A. Risk and uncertainty in mineral exploration: implications for valuing mineral exploration properties. Australian Institute of Geoscientists News, v. 100, p. 20-28, 2010. 
KREUZER, O. P.; ETHERIDGE, M. A.; GUJ, P. Australian junior exploration floats, 2001-06, and their implications for IPOs. Resources Policy, v.32, n. 4, p. 159-182, 2007.

LILFORD, E. Advanced methodologies for mineral project valuation. AIG Bulletin, v. $53,2011$.

NÚCLEO DE APOIO À PESQUISA PARA A PEQUENA MINERAÇÃO RESPONSÁVEL. Modelo peliminar do depósito de manganês da Fazenda Santana. São Paulo: USP/NAP, 2014. **

PALMIERI, M. Modelo geológico e avaliação de recursos minerais do depósito de nióbio Morro do Padre, complexo alcalino-carbonatítico Catalão II, GO. 2011 Dissertação (Mestrado) - Instituto de Geociências, Universidade de Brasília, 2011.

PARTINGTON, G. Developing models using GIS to assess geological and economic risk: an example from VMS copper gold mineral exploration in Oman. Ore Geology Reviews, v. 38, n. 3, p.197-207, 2010.

POPOFF, C. C. Computing reserves of mineral deposits: principles and conventional methods. Washington: US Dept. of the Interior, Bureau of Mines,1966. (Information Circular, v.8283).

RAGGI, J. Fusões e aquisições em Mineração. Geoconômica Minas, p.1-16, 2010.

RAMAZI, H.; MOSTAFAIE, K. Application of integrated geoelectrical methods in Marand (Iran) manganese deposit exploration. Arabian Journal of Geosciences, v. 6, n. 8, p. 2961-2970, 2013.

RIBEIRO, D. T. et al. Geostatistical approach for drilling pattern selection based on mineral resource risk assessment. REM: Revista Escola de Minas, v. 65, n. 1, p. 113-118, 2012.

SECCATORE, J.; DE TOMI, G.; VEIGA, M. Efficiency as a road to sustainability in small scale mining. Materials Science Forum, v. 805, p. 395-402, 2015.

SECCATORE, J. et al. A practical approach for the management of resources and reserves in small-scale mining. Journal of Cleaner Production, v. 84, p. 803-808, 2014.

SINGER, D. A.; KOUDA, R. Examining risk in mineral exploration. Natural Resources Research, v. 8, n. 2, p.111-122, 1999.

STEINBERG, J.; DE TOMI, G. Lean mining: principles for modelling and improving processes of mineral value chains. International Journal of Logistics Systems and Management, v. 6, n. 3, p. 279-298, 2010.

SZAMAŁEK, K. Rational mineral deposit management in the light of mineral resources theory. Gospodarka Surowcami Mineralnymi, v. 27, p. 5-15, 2011. 
THE AUSTRALASIAN INSTITUTE OF MINING AND METALLURGY.The Joint Ore Reserves Committee. Australasian code for reporting of exploration results: Mineral Resources and Ore Reserves. [200?]

TICHAUER, R. M. et al. Application of geophysics for mineral exploration in small-scale mining. In: Congresso Brasileiro de Mineração, 8., 2014, Belo Horizonte, MG. Anais. [s.L.: s.n.], 2014.

TILTON, J. E. On borrowed time: assessing the threat of mineral depletion. Routledge: [s.n.], 2010.

TUREK, M.; SOJDA, A. A fuzzy pay-off method for real option valuation in determination of mining enterprise value. International Journal of Computing, v. 13, n. 4 , p. 264-270, 2014.

UBERMAN, R. Valuation of mineral resources in selected financial and accounting systems. Natural Resources, 2014.

VILLEGAS, C. et al. Artisanal and small-scale mining in protected areas and critical ecosystems programme (ASM-PACE): a global solutions study. Nairobi: World Wide Fund for Nature and Estelle Levin, 2012.

** Documento acessível mediante autorização da Empresa/Instituição. 